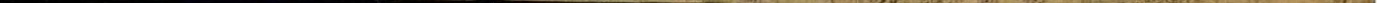


TEXAS TECH UNIVERSITY 


\section{$A D D-9996$}

DEPARTMENT OF THE INTERIOR

UNITED STATES GEOLOGICAL SURVEY

GEORGE OTIS SMITH, DIRECTOR

BULLetIN 562

\section{RESULTS OF SPIRIT LEVELING IN VIRGINIA}

1900 T0 1913, INCLUSIVE

R. B. marshall, Chief Geographer

Part of work since 1907 done in cooperation with State of Virginia through Virginia Geological Survey

T. L. Watson, State Geologist

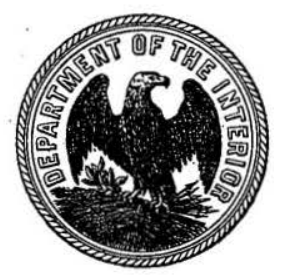

LIBRARY

TEXAS TECHNOLOGICAL COLLEGE

LUBBOCK, TEXAS

WASHINGTON

GOVERNMENT PRINTING OFFICE

1914 



\section{CONTENTS.}

$\begin{aligned} & \text { Page. }\end{aligned}$

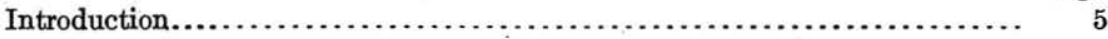

Cooperation.................................................. 5

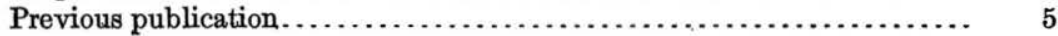

Personnel................................................. 5

Classification.................................................... 5

Bench marks................................................ 6

Datum....................................................... 6

Topographic maps. . . . .

Precise leveling..................................................... 8

Bonsacks, Cahas Mountain, Callaghan, Clarksville, Clifton Forge, Eagle Rock, Martinsville, Natural Bridge, and Rocky Mount quadrangles (Alleghany, Botetourt, Franklin, Henry, Mecklenburg, and Roanoke

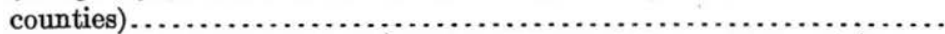

Bramwell and Peterstown quadrangles (Giles and Tazewell counties).....

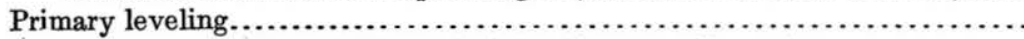

Hallwood and Snow Hill quadrangles (Accomac County)...............

Hampton, Isle of Wight, Surry, Toano, Williamsburg, and Yorktown quadrangles (Gloucester, Isle of Wight, James City, Surry, Warwick, and York counties).

Fairfax, Haymarket, Indian Head, Seneca, and Washington quadrangles (Fairfax, Loudoun, and Prince William counties).................

Boydton, Brookneal, Cahas Mountain, Callands, Chatham, Clarksville, Clover, Lynchburg, Moneta, Nathalie, and Virgilina quadrangles (Campbell, Charlotte, Halifax, Mecklenburg, and Pittsylvania counties)......

Bonsacks, Craigs Creek, Eagle Rock, and Natural Bridge quadrangles (Botetourt, Craig, and Rockbridge counties).......................

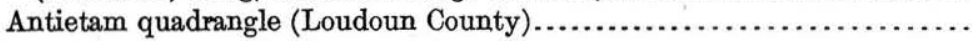

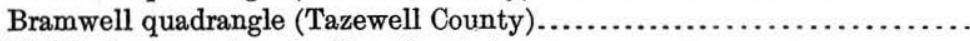

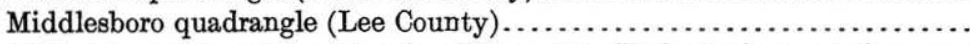

Abingdon quadrangle, embracing Damascus, Glade Springs, Marion, and Mount Rogers $15^{\prime}$ quadrangles (Grayson, Russell, Smyth, and Washington counties)

Big Stone Gap, Bramwell, Bucu, Burkes Garden, Clintwood, Coeburn, Glade Springs, Hagan, Hansonville, Middlesboro, Nolansburg, Pound, Pounding Mill, Regina, Richlands, Sneedville, and Wise quadrangles (Dickenson, Lee, Russell, Tazewell, and Wise counties)...............

Peterstown quadrangle (Giles County) ............................. Appendix A: Elevations adjusted by the Coast and Geodetic Survey from pre-

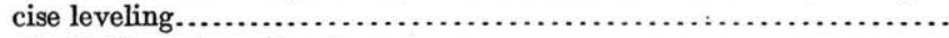
Appendix B: Secondary elevations............................... 62

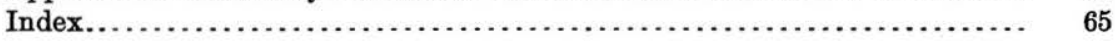

\section{ILLUSTRATION.}

Plate I. Geological Survey bench marks. 




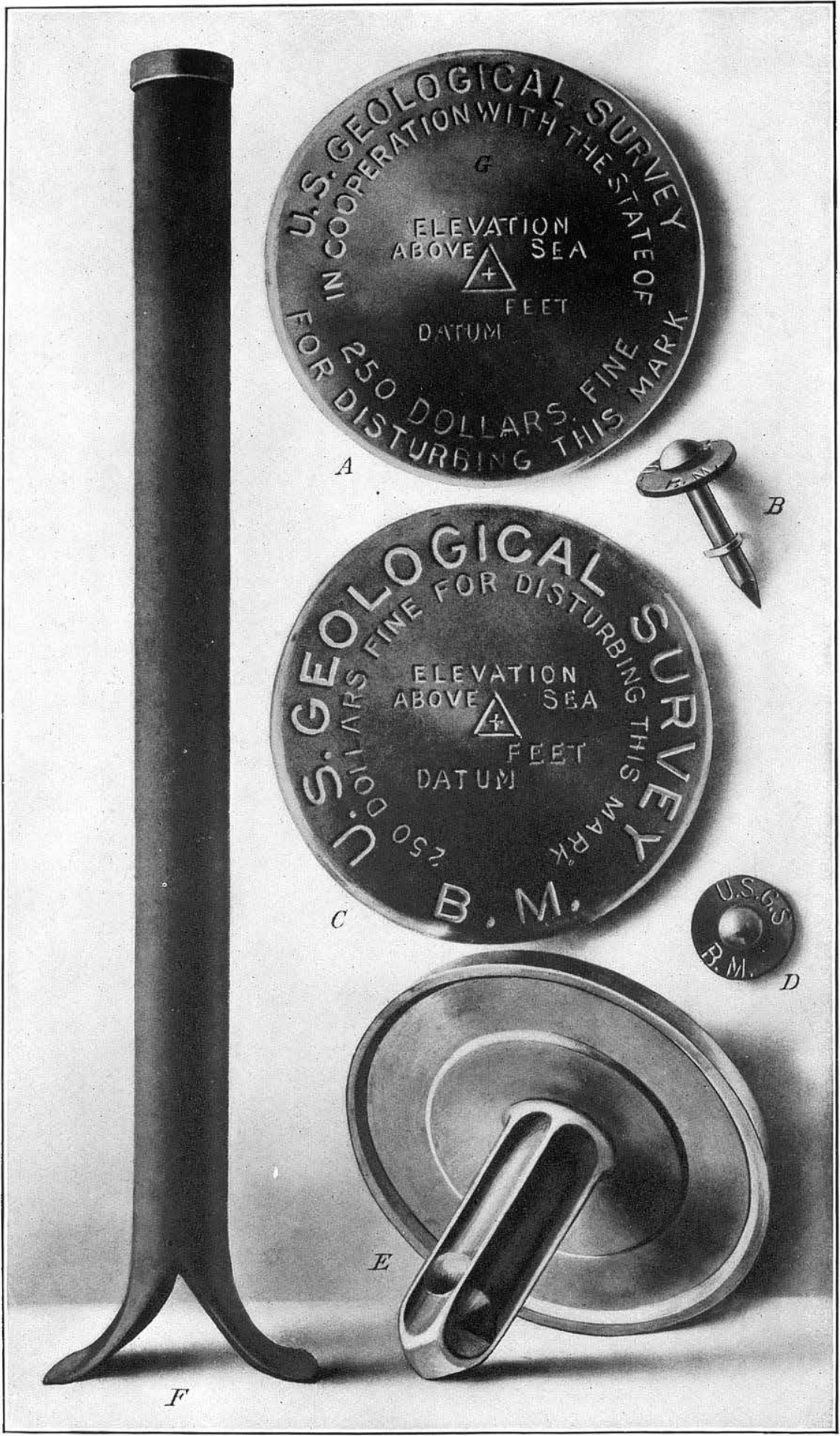

GEOLOGICAL SURVEY STATION MARKS.

$A$, Tablet used in cooperating States. The State name is inserted at $G$.

$B$ and $D$, Copper temporary bench mark, consisting of a nail and copper washer.

$A, C$, and $E$, Tablets for stone or concrete structures.

$F$, Iron post used where there is no rock. 


\section{RESULTS 0F SPIRIT LEVELING IN VIRGINIA, 1900 T0 1913, INCLUSIVE.}

R. B. Marshall, Chief Geographer.

\section{INTRODUCTION.}

Cooperation.-The State of Virginia contributed financially, through the Virginia Geological Survey, Thomas L. Watson, State Geologist, to part of the work done since 1907.

Previous publication.-That portion of the results of spirit leveling in Virginia previously published in Bulletin 434, containing descriptions and elevations of bench marks established in Delaware, District of Columbia, Maryland, and Virginia from 1896 to 1909, inclusive, and based on the 1903 adjustment, has been corrected to agree with the 1907 adjustment of precise leveling of the Coast and Geodetic Survey, and is here republished, together with the results of spirit leveling by the United States Geological Survey in Virginia since 1909. The elevations by the 1907 adjustment were not changed by the 1912 adjustment and are not likely to be changed by any future adjustment of the level net.

Personnel.-The field work from 1900 to 1906 , inclusive, was done under the direction of H. M. Wilson, geographer, and that from 1907 to 1911, inclusive, was done under Frank Sutfon, geographer. The work since January, 1908, was done under the general direction of R. B. Marshall, chief geographer. Credit is given in the headings of the several lists to the respective levelmen. The office work of computation, adjustment, and preparation of lists was done mainly by S. S. Gannett, geographer, under the general direction of E. M. Douglas, geographer.

Classification.-The elevations are classified as precise or primary, according to the methods employed in their determination. The former are determined by lines of levels run either in both forward and backward directions or by simultaneous double-rodded lines, a highgrade instrument being used and special precautions being taken in 
observations and reduction to correct errors and make the line continuously good throughout. The latter or primary levels are determined with the $Y$ level, precautions being taken against only the principal errors and the levels being run mostly in circuits of single lines. The allowable limit of error observed on the precise work already done by the Geological Survey in this State is represented in feet by $0.03 \sqrt{\mathrm{D}}$ and that for the primary work by $0.05 \sqrt{\mathrm{D}}$, in which $D$ is the length of circuit in miles.

Bench marks. - The standard bench marks are of two forms. The first form is a circular bronze or aluminum tablet ( $C$ and $E, \mathrm{Pl} . \mathrm{I}$ ), $3 \frac{1}{2}$ inches in diameter and $\frac{1}{4}$ inch thick, having a 3-inch stem, which is cemented in a drill hole in solid rock in the wall of some public building, a bridge abutment, or other substantial masonry structure. The second form $(F, \mathrm{Pl}$. I), used where masonry or rock is not available, consists of a hollow wrought-iron post $3 \frac{1}{2}$ inches in outer diameter and 4 feet in length. It is split at the bottom and spread out to a width of 10 inches in order to give a firm bearing on the earth, and is set about 3 feet in the ground. A bronze or aluminum-bronze cap is riveted upon the top of the post. A third style of bench mark with abbreviated lettering ( $B$ and $D, \mathrm{Pl}$. I), is used for unimportant points. This consists of a special copper nail $1 \frac{1}{2}$ inches in length driven through a copper washer $\frac{7}{8}$ inch in diameter. The tablets as well as the caps on the iron posts are appropriately lettered, and cooperation by States is indicated by the addition of the State name $(G, \mathrm{Pl}$. I).

The numbers stamped on the bench marks described in the following pages represent the elevations to the nearest foot as determined by the levelman. These numbers are stamped with $\frac{3}{16}$ inch steel dies on the tablets of post caps, to the left of the word "Feet." The office adjustment of the notes and the reduction to mean sea level datum may so change some of the figures that the original markings are 1 or 2 feet in error. It is assumed that engineers and others who have occasion to use the bench-mark elevations will apply to the Director of the United States Geological Survey, at Washington, D. C., for the adjusted values, and will use the markings as identification, numbers only.

Datum.-All United States Geological Survey. elevations are referred to mean sea level, which is the level that the sea would assume if the influence of winds and tides were eliminated. This level is not the elevation determined from the mean of the highest and the lowest tides, nor is it the half sum of the mean of all the high tides and the mean of all the low tides, which is called the half-tide level. Mean sea level is the average height of the water, all stages of the tide being considered. It is determined from observations made by 
means of tidal gages placed at stations where local conditions, such as long, narrow bays, rivers, and like features, will not affect the height of the water. To obtain even approximately correct results these observations must extend over at least one lunar month, and if accuracy is desired they must extend over several years. At ocean stations the half-tide.level and the mean sea level usually differ but little. It is assumed that there is no difference between the mean sea levels determined from observations in the Atlantic Ocean, the Gulf of Mexico, and the Pacific Ocean.

The connection with tidal stations for bench marks in certain areas that lie at some distance from the seacoast is still uncertain, and this fact is indicated by the addition of a letter or word to the right of the word "Datum" on tablets or posts. For such areas corrections for published results will be made from time to time as the precise-level lines of the United States Geological Survey or other Government organizations are extended.

Topographic maps.-Maps of the following quadrangles wholly or partly in Virginia have been published by the United States Geological Survey up to September 1, 1914. They may be obtained for 10 cents each or $\$ 3$ for 50, except as otherwise noted, on application to the Director of the Survey at Washington, D. C.

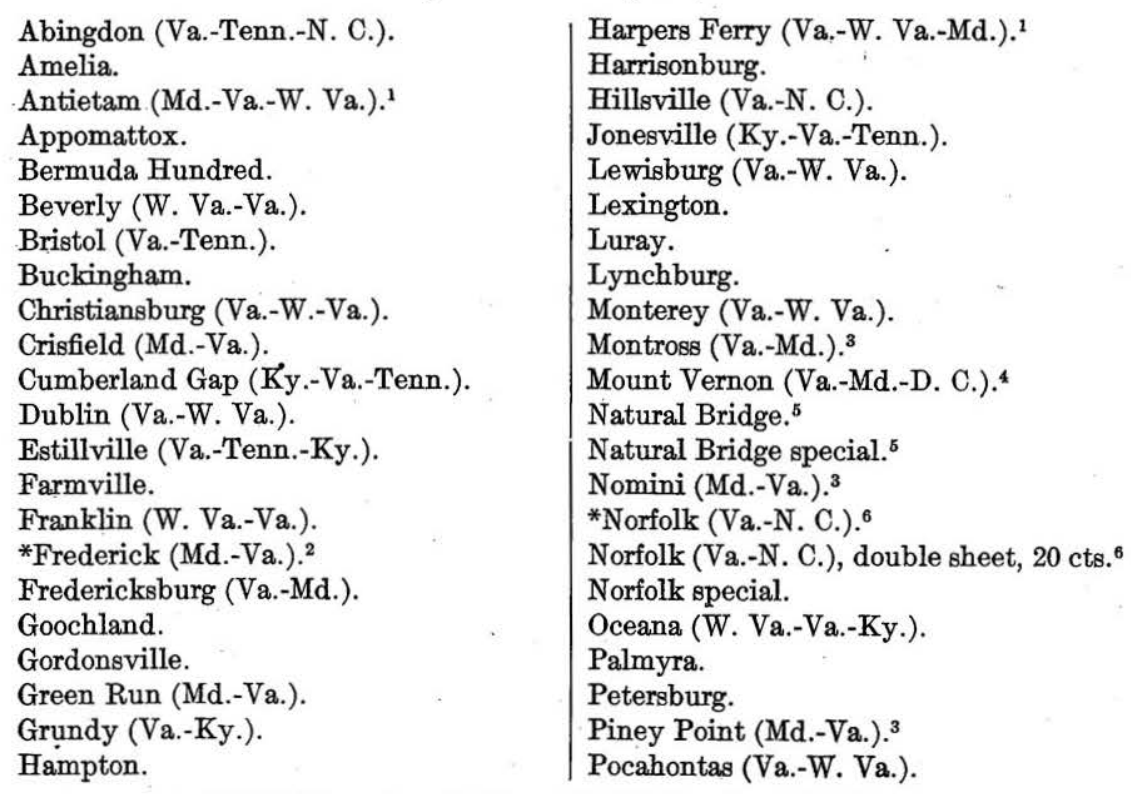

* Out of print.

1 Antietam sheet shows part of Harpers Ferry quadrangle on larger scale.

2 Rockville and Seneca sheets show parts of Frederick quadrangle on larger scale.

${ }^{3}$ Montross, Piney Point, and Wicomico sheets, on scale of 1:62,500, have been reduced and form parts of Nomini sheet, on scale of $1: 125,000$.

4The west half of Washington sheet shows part of Mount Vernon quadrangle on larger scale.

${ }^{5}$ Natural Bridge special sheet shows part of Natural Bridge quadrangle on larger scale.

6 Norfolk double sheet includes Norfolk and Virginia Beach sheets. 
Point Lookout (Md.-Va.). ${ }^{1}$

Princess Anne (Md.-Va.).

Richmond.

Roanoke.

Rockville (Md.-Va.). ${ }^{2}$

Romney (W. Va.-Va.-Md.).

St. Marys (Md.-Va.). ${ }^{1}$

Seneca (Md.-Va.). ${ }^{2}$

Snow Hill (Md.-Va.).

Spotsylvania.

Staunton (Va.-W. Va.).

Tazewell (Va.-W. Va.).

Virginia Beach (Va.- N. C.). ${ }^{3}$
Warfield (W. Va.-Ky.-Va.).

Warrenton.

Washington (Md.-D. C.-Va.), double sheet, 20 cents. 456

${ }^{*}$ West Washington (Md.-D. C.-Va.). ${ }^{45}$

Whitesburg (Ky.-Va.).

Wicomico (Md.-Va.). ${ }^{7}$

Williamsburg. ${ }^{8}$

Winchester (Va.-W. Va.).

Woodstock (Va.-W. Va.).

Wytheville (Va.-N. C.).

Yorktown. ${ }^{8}$

\section{PRECISE LEVELING.}

Bonsacks, Cahas Mountain, Callaghan, Clarksville, Clifton Forge, Eagle Rock, Martinsville, Natural Bridge, and Rocky Mount quadrangles.

\section{ALLEGHANY, BOTETOURT, FRANKLIN, HENRY, MECKLENBURG, AND ROANOKE COUNTIES.}

The following list embodies the Virginia portion of the results of two lines of precise levels. The first line, a spur from Durham, N. C., to Clarksville, Va., was run in 1905 by R. L. Libbey. The second line, from Greensboro, N. C., to Lock No. 6, near Charleston, W. Va., was run in three sections: (1) From Greensboro, N. C., to Buchanan, Va., along the Norfolk \& Western Ry., in 1905, by R. L. Libbey; (2) from Buchanan to Moss Run, along the Chesapeake \& Ohio Ry., in 1906, by N. A. Campbell; and (3) from Moss Run to Lock No. 6, along the Chesapeake \& Ohio and the Kanawha \& Michigan railways, in 1907 , by C. H. Semper.

The closure error of the second line upon the United States Army Engineer Corps elevation at Lock No. 6, corrected to accord with the 1903 adjustment, was 0.732 foot high; but this error has been removed by adjustment over a total distance of 365 miles.

\section{CLARKSVILLE QUADRANGLE.}

[Latitude $36^{\circ} 30^{\prime}-36^{\circ} 45^{\prime}$; longitude $78^{\circ} 30^{\prime}-78^{\circ} 45^{\prime}$.]

From Soudan north to Clarksville.

Soudan, 125 feet west of south switch of siding, in southeast corner of W. L. Feet. Averett's yard; iron post stamped " 312 " (b. m. U)................ 311.964

Clarksville, 2.5 miles south of, 60 feet west of Southern Ry. tracks, at edge of woods, directly opposite milepost 34 ; iron post stạmped " 326 " (b. m. V)

* Out of print.

1 Point Lookout sheet shows part of St. Marys quadrangle on larger scale.

${ }^{2}$ Rockville and Seneca sheets show parts of Frederick quadrangle on larger scale.

${ }^{3}$ Norfolk double sheet includes Norfolk and Virginia Beach sheets.

- The west half of Washington sheet shows part of Mount Vernon quadrangle on larger scale.

5 Washington sheet shows the same area as East Washington and West Washington sheets.

6 The east half of Washington sheet, on scale of 1:62,500, has been reduced and forms part of Patuxent sheet, on scale of $1: 125,000$.

7 Montross, Piney Point, and Wicomico sheets, on scale of 1:62,500, have been reduced and form parts of Nomini sheet, on scale of 1:125,000.

8 Shows wooded areas. 
Clarksville, 25 feet south of lower station, 5 feet above track, in face of rock cut; aluminum tablet stamped " 286 " (b. m. W)......................

Clarksville, on south side of Main Street, between sidewalk and gutter, 125 feet west of tracks; iron post stamped " 286 " (b. m. X)................. Clarksville, in southeast corner of west abutment pier of Southern Ry.

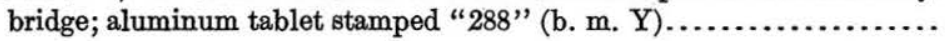

\section{MARTINSVILLE QUADRANGLE.}

[Latitude $36^{\circ} 30^{\prime}-36^{\circ} 45^{\prime}$; longitude $79^{\circ} 45^{\prime}-80^{\circ}$.]

\section{From Price, N. C., north along Norfolk \& Western Ry. to Bassett.1}

Ridgeway, in front of station; top of rail

840.8

Ridgeway, 175 feet northeast of station; 85 feet east of railroad track, 30 feet east of county road, nearly opposite road-crossing sign; iron post stamped " 834 "

285.886

287.568

Ridgeway, 3.5 miles north of, 200 feet northwest of milepost 54, 600 feet south of mail crane, 50 feet west of railroad track; iron post stamped " 720 "

Martinsville, in front of station; top of rail. .........................

Martinsville, 350 feet northwest of station, 300 feet north of railroad track, 10 feet east of College Street, in southwest corner of S. F. Pedigo's yard; iron post stamped " 947 "

Martinsville, 2.5 miles northwest of, 60 feet west of Martinsville-Bassett wagon road, 40 feet north of railroad track, 600 feet northwest of milepost 62 ; iron post stamped " 773 "

Martinsville, 5.5 miles north of, 660 feet north of milepost 64 , in south abutment of concrete railway culvert 1,870 ; aluminum tablet stamped " 729 ".

Bassett, 3.5 miles south of, 200 feet south of milepost 66, in west side of first stone culvert south of milepost 66 ; square cut.........................

\section{ROCKY MOUNT QUADRANGLE.}

[Latitude $36^{\circ} 45^{\prime}-37^{\circ}$; longitude $79^{\circ} 45^{\prime}-80^{\circ}$.]

From Bassett along Norfolk \& Western Ry. to Rocky Mount.

Bassett, in front of station; top of rail.............................

Bassett, near southeast corner of yard of Jasper Bassett, outside of front fence, 10 feet west of wagon road, 75 feet southwest of road crossing, nearly opposite Bassett furniture factory; iron post stamped " 762 "......

Town Creek, 200 feet northeast of Philpotts's store, 200 feet southeast of milepost 73, southeast of railroad; iron post stamped " 798 "

Town Creek, 0.25 mile north of, 120 feet northwest of railway crossing, in top of southeast wing wall of railway bridge 1860; aluminum tablet stamped " 803 "

758. 6

761. 566

797. 387

803. 198

Henry, 0.5 mile south of, in top of northwest wing wall of concrete railway bridge 1857 ; aluminum tablet stamped " 882 ". ....................

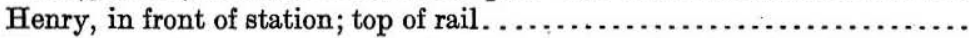

Henry, 0.5 mile north of, near end of first curve north of station, 25 feet west of tracks, 200 feet west of river; iron post stamped " 905 ".

Henry, 3 miles north of, in northwest wing wall of concrete railway bridge 1849 , about 500 feet southwest of milepost 81 ; aluminum tablet stamped " 1089 "

904. 681

Ferrum, 200 feet north of H. E. Menifee's store, 100 feet west of railroad tracks, in vacant lot owned by H. E. Menifee, 2 feet west of fence and roadway; iron post stamped " 1296 ". 
Feet.

Ferrum, in front of station; top of rail . . . . . . .

Ferrum, 2 miles north of, in first masonry culvert north of station, 300 feet northeast of milepost 86 ; square cut............................ 1, 196. 334

Waidsboro, 40 feet west of railway tracks, 10 feet north of public road, opposite south switch signal; iron post stamped " 1264 "................ 1, 263.865

Saunders siding, 60 feet east of railway track, opposite sign "Water 1 mile," 100 feet northeast of switch, opposite rear of Saunders's store; iron post stamped "1084"

Rocky Mount, midway between the Norfolk \& Western and Southern railways, near crossing, 500 feet southwest of milepost 94,200 feet southwest of Norfolk \& Western station; iron post stamped " 1146 "......... 1, 145. 377

Rocky Mount, in front of station; top of rail. .................... 146.4

\section{CAHAS MOUNTAIN QUADRANGLE.}

[Latitude $37^{\circ}-37^{\circ} 15^{\prime}$; longitude $79^{\circ} 45^{\prime}-80^{\circ}$.]

From Rocky Mount along Norfolk \& Western Ry. to point 4 miles south of Roanoke.

Rocky Mount, 1.8 miles east of, in southeast wing wall of concrete railway culvert 1828, about 700 feet northeast of sign " 1 mile to station;"' aluminum tablet stamped " 1106 "............................. 1, 106. 274

Wirtz, 1.5 miles south of, 400 feet north of railroad-crossing sign, 20 feet east of track, in first concrete culvert south of milepost 99; aluminum tablet stamped " 1067 ".

Wirtz, 600 feet south of station, 50 feet east of railway, 90 feet southeast of A. J. McNeil's store, 10 feet south of wagon road; iron post stamped "1128".

Wirtz, in front of station; top of rail .......................... 1, 121.3

Boones Mills, 3 miles south of, 700 feet northwest of milepost 103, 503 feet southwest of road, in northwest abutment of trestle 1819; aluminum

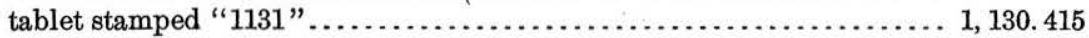

Boones Mills, 60 feet northeast of station; 40 feet south of wagon road, opposite store of C. W. Mills \& Co.; iron post stamped " 1128 "......... 1, 127.915

Nore.-Post was moved S. $48^{\circ}$ E. 36.75 feet Nov. 11, 1912; elevation not changed.

Wright, 1 mile south of, 500 feet north of milepost 111, in west side of stone culvert; aluminum tablet stamped " 1171 ".................... 1, 170.567

Wright, 800 feet south of station, 500 feet south of milepost 110,20 feet east of track; iron post stamped " 1108 "........................... 1, 107.700

Starkey, 500 feet north of station, in east side of stone culvert, opposite water tank; square cut........................................ 1, 138.579

Starkey, in front of station; top of rail............................ 138. 7

Roanoke, 4 miles south of, 600 feet south of milepost 117, east side of stone culvert; aluminum tablet stamped " 1086 "....................... 1, 085.956

\section{BONSACKS QUADRANGLE.}

[Latitude $37^{\circ} 15^{\prime}-37^{\circ} 30^{\prime}$; longitude $79^{\circ} 45^{\prime}-80^{\circ}$.]

From point 4 miles south of Roanoke along Norfolk \& Western Ry. to Lithia.

Roanoke, 1.5 miles south of, in southwest abutment of railway bridge over Roanoke River; aluminum tablet stamped " 937 ".................

Roanoke, in southwest corner of Hotel Roanoke grounds, near Shenandoah Avenue and Jefferson Street gate, 80 feet north of Jefferson Street railroad crossing; iron post stamped " 924 " 
Roanoke, in south abutment of First Street viaduct, 270 feet west of Salem Avenue, facing railroad tracks; aluminum tablet stamped " 925 "........

Roanoke, in front of station; top of rail..........................

Hollins, 50 feet east of track, 40 feet southeast of station, near northwest corner of S. V. Nininger's yard; iron post stamped " 1169 ".

Hollins, in front of station; top of rail........................... 165. 3

Cloverdale, in southwest corner of fenced right of way, back of section tool house, 100 feet northwest of station, 10 feet north of wagon road; iron post stamped " 1133 "

Troutville, 2 miles south of, 500 feet north of milepost 9 , in northwest stone abutment of plate-girder bridge; aluminum tablet stamped " 1266 ".... 1, 265.411

Troutville, in railroad right of way, opposite and 50 feet west of station, 6 feet west of telegraph pole; iron post stamped " 1405 ".............. 1,404.598

Troutville, 270 feet north of station, 60 feet north of south switch, in west side of first stone culvert north of station; aluminum tablet stamped

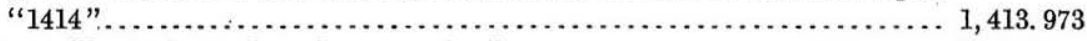

Troutville, in front of station; top of rail......................... 1,407.7

Nace, 100 feet west of station, on railroad right of way, 75 feet southwest of road crossing, 20 feet south of wagon road; iron post stamped " 1356 " ... 1, 356. 034

Nace, 2 miles north of, in southwest wing wall of iron railway bridge 411 over Back Creek; aluminum tablet stamped " 1170 "

Lithia, in front of station; top of rail.

Lithia, 90 feet west of railway tracks, opposite station, 10 feet south of east of J. W. Shirley's store, near fence corner; iron post stamped " 978 ".....

978. 058

\section{NATURAL BRIDGE QUADRANGLE.}

[Latitude $37^{\circ} 30^{\prime}-37^{\circ} 45^{\prime}$; longitude $79^{\circ} 30^{\prime}-79^{\circ} 45^{\prime}$.]

From point 3 miles south of Buchanan north along Norfolk \& Western Ry. to Buchanan, thence northwest along Chesapeake \& Ohio Ry. to Saltpetre Cave.

Buchanan, 3 miles south of , 1,000 feet north of milepost 22, near cattleguard, in east side of stone culvert; aluminum tablet stamped " 876 "..........

Buchanan, in front of Norfolk \& Western Ry. station; top of rail..........

Buchanan, on High Street, near southeast corner of Presbyterian Church; iron post stamped " 862 ".

875. 355

883.3

Buchanan, in northwest abutment of wagon bridge near Chesapeake \& Ohio Ry. passenger station; aluminum tablet stamped " 832 ".........

Buchanan, in front of Chesapeake \& Ohio Ry. station; top of rail.........

Buchanan, 3.5 miles west of, at telegraph station; top of rail...............

Springwood, on northwest abutment of wagon bridge over James River; aluminum tablet stamped " 856 ".

861. 394

831.854

829.8

849.2

Springwood, in front of station; top of rail

855.628

Springwood, 2.3 miles west of, northwest abutment of railroad bridge; aluminum tablet stamped " 887 " ................................

Saltpetre Cave, in front of station; top of rail........................

Saltpetre Cave, in southeast corner of east abutment at south side of railroad trestle over stream, 100 feet west of station; aluminum tablet stamped " 895 "

887.550

895.8 


\section{EAGLE ROCK QUADRANGLE.}

[Latitude $37^{\circ} 30^{\prime}-37^{\circ} 45^{\prime}$; longitude $79^{\circ} 45^{\prime}-80^{\circ}$.]

From Springwood along Chesapeake \& Ohio Ry. to Glen Wilton.

Burketons, in front of telegraph station; top of rail........................

Salisbury, in front of station; top of rail..............................

Salisbury, on northeast abutment of railroad bridge; aluminum tablet stamped " 913 ".

Feet.

900. 6

915. 4

912.569

932.0

934.550

936.1

939.0

954.414

955.6

955.872

962.3

985.930

987.1

983. 6

991.6

999.4

996.251

\section{CLIFTON FORGE QUADRANGLE.}

[Latitude $37^{\circ} 45^{\prime}-38^{\circ}$; longitude $79^{\circ} 45^{\prime}-80^{\circ}$.]

From Lick Run along Chesapeake \& Ohio Ry. to Covington.

Lick Run, in front of station; top of rail....................... 1,003.8

Lick Run, 0.6 mile west of, rock cut; aluminum tablet stamped "1017".. 1, 016. 584

Lick Run, 1.1 miles west of, road crossing; top of rail.................. 1,026.3

Lick Run, 1.5 miles west of, Alleghany-Botetourt county line; top of rail. 1, 025. 54

Iron Gate, in front of station; top of rail......................... $1,028.7$

Iron Gate, 0.3 mile west of, road crossing; top of rail................. $1,030.9$

Clifton Forge, on railroad bridge abutment, east of station; aluminum tab-

let stamped " 1064 "........................................... 1,063.419

Clifton Forge, in front of station; top of rail......................... 1, 065. 7

Clifton Forge, 3.3 miles west of, road crossing; top of rail............... 1, 127.2

Clifton Forge, 3.3 miles west of, culvert; aluminum tablet stamped "'1127". 1, 126. 680

Lowmoor, in front of station; top of rail......................... 145. 8

Lowmoor, 2.9 miles west of, south of track, in rock ledge; aluminum tablet stamped " 1198 ".

Lowmoor, 5.1 miles west of, in east abutment of railroad bridge over river; aluminum tablet stamped " 1198 "............................ 1, 197.547

Mallow, in front of station; top of rail............................ $1,216.2$

Mallow, 2.1 miles west of, road crossing; top of rail.................. 1,263.6

Mallow, 3 miles west of, road crossing; top of rail................. 1,246.5

Covington, in front of station; top of rail...................... 1,252.5

Covington, 0.4 mile west of; road crossing........................ $1,255.2$

Covington, 0.6 mile west of, in abutment of iron railroad bridge over river;

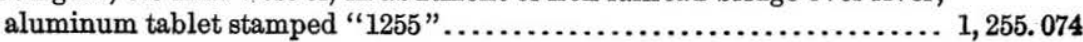


CALLAGHAN QUADRANGLE.

[Latitude $37^{\circ} 45^{\prime}-38^{\circ}$; longitude $80^{\circ}-80^{\circ} 15^{\prime}$.]

From Covington along Chesapeake \& Ohio Ry. to Alleghany.1

Covington, 2.8 miles west of, on northwest abutment of railroad bridge over Feet. river; aluminum tablet stamped " 1304 "......................... 1, 303.896

Covington, 4.8 miles west of, in bridge abutment; aluminum tablet stamped

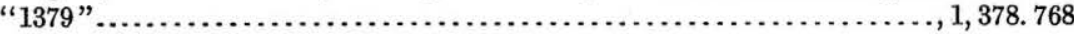

Callaghan, in front of station; top of rail....................... 1,425.9

Moss Run, in front of station; top of rail........................ 1, 575.2

Moss Run, 0.9 mile west of, 396 feet west of milepost "Ft. M 299," south side of track, in face of wall in rock cut; aluminum tablet stamped

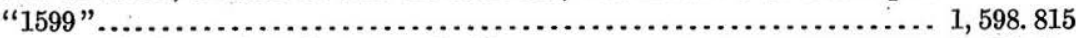

Backbone, in front of station; top of rail........................ 1, 729.6

Backbone, 380 feet west of, southeast foundation stone of water tank, north side of track; aluminum tablet stamped " 1733 "................... 1,733.079

Jerrys Run, in face of rock at rear of east end of station; aluminum tablet

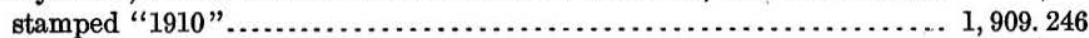

Jerrys Run, in front of station; top of rail...................... 1, 906. 1

East Alleghany, in front of station; top of rail.................... 2039.7

Alleghany, 350 feet east of station, north face of east abutment of bridge under track; aluminum tablet stamped " 2049 "...................... 2, 047.420

Alleghany, in front of station; top of rail............................. 070.6

Bramwell and Peterstown quadrangles.

GILES AND TAZEWELL COUNTIES.

The following is the Virginia portion of the unadjusted results of a line of precise levels run from Hinton, W. Va., south along highway to Glenlyn, Va., thence west along Norfolk \& Western Ry. to Graham, Va., based upon an elevation at Hinton, determined by precise leveling adjusted to agree with the 1912 adjustment. The leveling was done by two parties joining at a point 2 miles west of Oakvale. Yard rods and prism levels were used and the latest method was followed. The total length of double line is 57.8 miles and the total divergence was plus 0.155 foot. For elevations in the West Virginia portion of these quadrangles see Bulletin 477.

The leveling was done in 1909 in Peterstown quadrangle by C. H. Semper and in Bramwell quadrangle by T. A. Green.

\section{PETERSTOWN QUADRANGLE.}

[Latitude $37^{\circ} 15^{\prime}-37^{\circ} 30^{\prime}$; longitude $80^{\circ} 45^{\prime}-81^{\circ}$.]

At Glenlyn.

Feet.

Glenlyn, opposite station, on east-bound track; top of rail. $1,532.1$

Glenlyn, 528 feet west of, on south side of Norfolk \& Western Ry., 8 feet south of track, in top of railroad culvert; aluminum tablet stamped " 1535 "

BRAMWELL QUADRANGLE.

[Latitude $37^{\circ} 15^{\prime}-37^{\circ} 30^{\prime}$; longitude $81^{\circ} 15^{\prime}-81^{\circ} 30^{\prime}$.]

At Graham.

Graham, west side of front entrance to Bank of Graham, in third step above pavement; aluminum tablet stamped " $2389 "$ "....................... 2, 389.450.

1 For continuation of this line in West Virginia see Bulletin 399. 


\section{PRIMARY LEVELING.}

Hallwood and Snow Hill quadrangles.

\section{ACCOMAC COUNTY.}

The elevations in the following list, based on tidal observations made by the Coast and Geodetic Survey at Franklin City, form part of a net of levels carried from Baltimore. (See Maryland list, Bulletin 563.) The leveling was done in 1900 by J. W. Hodges.

HALLWOOD QUADRANGLE.

[Latitude $37^{\circ} 30^{\prime}-37^{\circ} 45^{\prime}$; longitude $75^{\circ} 30^{\prime}-75^{\circ} 45^{\prime}$.]

From Pocomoke City south to Massey.

Massey, at New Church station of the New York, Philadelphia, \& Norfolk Feet.

R. R.; iron post stamped " 24 Balto"......................... 23. 751

Nоте.-Upper part of post was broken off accidentally in 1909.

SNOW HILL QUADRANGLE.

[Latitude $38^{\circ}-38^{\circ} 15^{\prime}$; longitude $75^{\circ} 15^{\prime}-75^{\circ} 30^{\prime}$.]

At Franklin City.

Franklin City, in front of post-office building, in foundation wall; bronze tablet stamped "4 Balti"

Hampton, Isle of Wight, Surry, Toano, Williamsburg, and Yorktown quadrangles.

GLOUCESTER, ISLE OF WIGHT; JAMES CITY, SURRY, WARWICK, AND YORK CO UNTIES.

The elevations in the following list are based on the latest adjusted heights along the Coast and Geodetic Survey precise-level line from Newport News. In crossing the James and York rivers, synchronous gage records were made for rising and falling tides.

The leveling in Toano, Williamsburg, Yorktown, and Surry quadrangles was done in 1904 by T. A. Green; in Hampton quadrangle in 1906 by R. S. Deemer.

\section{TOANO QUADRANGLE.}

[Latitude $37^{\circ} 15^{\prime}-37^{\circ} 30^{\prime}$; longitude $76^{\circ} 45^{\prime}-77^{\circ}$.]

At Croaker.

Croaker, 25 feet east of road forks, directly south of post office and store kept by K. K. Tyssen; iron post stamped "107 Adj 1903."

Feet. 107. 360

WILLIAMSBURG QUADRANGLE.

\section{[Latitude $37^{\circ} 15^{\prime}-37^{\circ} 30^{\prime}$; longitude $76^{\circ} 30^{\prime}-76^{\circ} 45^{\prime}$.]}

From Williamsburg north along highway to Croaker, thence northeast, crossing York River to Signpine, thence southeast via Sassafras to Gloucester, thence south to Gloucester Point.

Williamsburg, in east side of post office, in fourth brick from northeast corner; aluminum tablet stamped "84 Adj 1903"..................

Williamsburg, 4.8 miles north of, at main road forks 1.3 miles west of Magruder post office, just south of road forks, on east side of road, at edge of Mr. Crest's farm; iron post stamped "82 Adj 1903".

84.524 
Oaktree, 2.1 miles northwest of, junction with main road, 1.4 miles northeast of Lightfoot, east side of road, just south of forks, on edge of William Maboul's farm; iron post stamped "115 Adj 1903".

Feet.

Croaker, 3.6 miles northeast of, south of York River, 0.2 mile north of mouth of Taskinas Creek, on ground of the Wilburg H. Davis estate, post is planted near southeast corner of kitchen of residence, on south side; iron post stamped "39 Adj 1903".

West End, north of York River, west of road, 300 feet west of small creek, on Captain Coleman's estate, 75 feet south of house occupied by Moses Roe; iron post stamped " 3 Adj 1903 "

Signpine, 1.1 miles south of crossroads, west of oak tree standing in road;

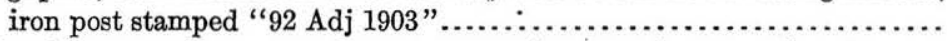

Sassafras post office, at southwest corner of crossroads, at northeast corner on north side B. C. Newcomb's store; iron post stamped “97 Adj 1903".

Gloucester, in fifth brick from northwest corner at west side of building owned and occupied by L. E. Mumford Banking Co., in tenth course of bricks above ground; aluminum tablet stamped "76 Adj 1903 ".......

Whitemarsh post office, west of road, at junction with road running west, just north of forks, in southeast corner of J. R. Newcomb's store; iron post stamped "55 Adj 1903"

115.034

38. 602

97.174

76. 155

54. 966

Ordinary post office, 1 mile south of west of road, near southeast corner of W. H. Hoggs's store; iron post stamped "39 Adj 1904"...............

YORKTOWN QUADRANGLE.

[Latitude $37^{\circ}-37^{\circ} 15^{\prime}$; longitude $76^{\circ} 30^{\prime}-76^{\circ} 45^{\prime}$.]

From Gloucester Point across York River to Yorktown, thence southeast to Lee Hall.

Gloucester Point post office, at south side, near southwest corner of store kept by J. A. Taliaferro; iron post stamped "5 Adj 1903 ".

Yorktown post office, 300 feet west of boat wharf, west of road, at corner of lot owned by R. W. Shields; iron post stamped "6 Adj 1903 ". . . . . . .

Halsteads Point, 1.1 miles south of, east side of Lebanon Church, in third brick from northeast corner, in tenth course of bricks above ground; aluminum tablet stamped " 82 Adj 1903 " ......................

From Williamsburg southeast along Chesapeake \& Ohlo Ry. to Denbigh.

Grove, on south side of post office, near southeast corner; iron post stamped " 89 Adj 1903 ".

Lee Hall, 1.9 miles southeast of, pumping station at reservoir, on east side of pump house, in south end of large stone forming doorsill of front entrance; aluminum tablet stamped "25 Adj 1903 "..................

Denbigh, in fifth brick from northeast corner (east side) of brick courthouse, in tenth course of bricks above ground; aluminum tablet stamped

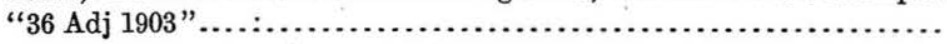

From Springfield northwest via Septa and Bacons Castle 1 to Highgate.

Septa, just southeast of road forks, on west side near south corner of post office and store kept by J. H. Edward; iron post stamped "86 Adj 1903 "..

Septa, 3 miles northwest of, just south of Moonlight crossroads, west of road, on lot owned by W. L. Ward; iron post stamped " 84 Adj 1903"........

Septa, 5.3 miles northwest of, at junction with second-class road east, just south of forks, at northwest corner of lot owned by J. G. Goodrich, 25 feet southeast of Ferguson Grove Baptist Church; iron post stamped " 92 Adj

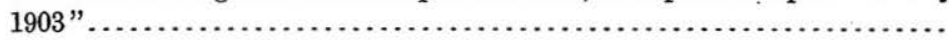

${ }^{1}$ An error of 1 foot between Battery Park and Scotland was adjusted arbitrarily by placing it south of Bacons Castle. 
Bacons Castle, just south of crossroads, on east side of road, near southwest corner of store and post office; iron post stamped "84 Adj 1903".

Highgate, at store and post office at main forks of road; iron post stamped "75 Adj 1903"

ISLE OF WIGHT QUADRANGLE.

[Latitude $36^{\circ} 45^{\prime}-37^{\circ}$; longitude $76^{\circ} 30^{\prime}-76^{\circ} 45^{\prime}$.]

From Newport News west across James River to Battery Park, thence west to Springfleld.

Battery Park, 25 feet south of boat wharf, at northwest corner (north side) of J. G. Wilson's store; iron post stamped."5 Adj 1903".

Smithfield, in west side (second brick from north side) of store owned by T. J. Cox, in seventeenth course of bricks above ground; bronze tablet stamped "Prim. Trav. Sta. No. 209 A, 12"

\section{SURRY QUADRANGLE.}

\section{[Latitude $37^{\circ}-37^{\circ} 15^{\prime}$; longitude $76^{\circ} 45^{\prime}-77^{\circ}$.]}

From Highgate northwest to Scotland, thence across James River to Jamestown, thence northeast to Williamsburg.

Highgate, 2.2 miles northwest of, north of road just east of main forks, at southeast corner of store; iron post stamped "74 Adj 1903".............

Scotland, at southeast corner east side of store kept by Mrs. W. E. Adams; iron post stamped "7 Adj 1903 ".

Jamestown, on land owned by the Association for the Preservation of Virginia Antiquities, at northwest corner of barn, on old church grounds; iron post stamped "9 Adj 1903"

HAMPTON QUADRANGLE.

[Latitude $37^{\circ}-37^{\circ} 15^{\prime}$; longitude $76^{\circ} 15^{\prime}-76^{\circ} 30^{\prime}$.]

From Yorktown southeast to point near North Newport News (mean of direct and reverse lines).

Yorktown, 3.1 miles southeast of, on Hampton-Yorktown road, at northwest corner of road southwest, 0.8 mile northwest of Harris Grove; iron post stamped " 65 ".

Grafton, 0.4 mile northeast of, south of Hampton-Yorktown road, 300 feet north of wood line; iron post stamped " 56 ".

Kings Corners, 0.4 mile northeast of, 0.2 mile southwest of Zion Church (colored); iron post stamped " 36 ".

Moores Place, 0.1 mile southwest of, 0.4 mile east of negro Bethel Church, east of Hampton-Yorktown road; iron post stamped " 31 ".............

Little Bethel Church, on Yorktown-Hampton road, 5.5 miles northeast of Hampton; iron post stamped " 20 "

From point near North Newport News to Newport News.

Newport News, 3.99 miles north of, road crossing on Chesapeake \& Ohio Ry., southwest corner of; iron post stamped " 30 " 1

From point 6 miles north of Newport News southeast via Hampton to Old Point Comfort.

Hampton, 2 miles west of, on Hampton-Yorktown road, center of triangle

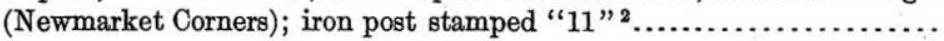

1 Not adjusted; closure on Coast and Geodetic Survey bench mark -0.496 foot.

2 Not adjusted; closure on Coast and Geodetic Survey bench mark -0.501 foot. 
Fairfax, Haymarket, Indian Head, Seneca, and Washington quadrangles.

FAIRFAX, LOUDOUN, AND PRINCE WILHAM COUNTIES.

The elevations in the following list were determined by primary leveling and accord with Bulletin 434, being unchanged by the 1912 adjustment.

The leveling was done in 1911 in Fairfax, Haymarket, Seneca, and Washington quadrangles by E. E. Witherspoon, and in Indian Head quadrangle by J. B. Metcalfe. Additional leveling was done in the Washington quadrangle in 1912 by F. J. McMaugh and D. H. Baldwin. All of these levelmen used wye levels except Baldwin, who used a prism level. Part of the leveling in Seneca quadrangle was done in 1906 by R. A. Farmer.

\section{FAIRFAX QUADRANGIE.}

[Latitude $38^{\circ} 45^{\prime}-39^{\circ}$; longitude $77^{\circ} 15^{\prime}-77^{\circ} 30^{\prime}$.]

\section{From Forestwille south along highways to point near Andrew Chapel.}

Forestville, near southeast corner of east foundation of Oliver's store; tab-

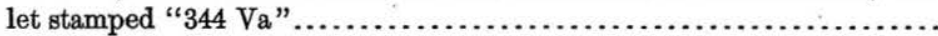

Forestville, 1 mile south of, on east end of south abutment of bridge over Cabin Hickory Run, at bend of road to west; chiseled square marked " $240 "$

Feet.

344.405

236. 91

309. 28

of road to Forestville; chiseled square on rock marked " 312 "

Forestville, 3.1 miles south of, 300 feet east of road to south, 10 feet south of road, 60 feet north of house; copper nail in root of 15 -inch cedar tree marked " 268.4 "

265.47

Kenmore, 0.2 mile east of, 100 feet east of public road south, 10 feet north of road; copper nail in root of 18 -inch cherry tree marked " 347.7 "........

Andrew Chapel, 0.6 mile east of, 10 feet north of road at fork; iron post stamped " 366 "

From point near Ilda west and north along public road to sterling.

Ilda, 1.3 miles west of, 200 feet east of road north, 20 feet south of turnpike, south of fence; nail in root of 4-inch cedar tree marked " 386 " .........

Ilda, 2.2 miles west of, 300 feet west of road south, west of bridge, 12 feet north of turnpike, in front of house; nail in root of 24-inch locust tree marked " 413 ".

Fairfax Courthouse, on west edge of top of steps leading to courthouse; tablet stamped " 447 ".

Fdirfax Courthouse, opposite courthouse, in front of cobbler shop under Fairfax Hotel, near edge of porch; chiseled square on west edge of cement pavement.

Fairfax Courthouse, 1.1 miles west of, 20 feet north of turnpike at junction of turnpikes, in root of 7-inch cedar tree; copper nail marked " 424.8 "..

Fairfax Courthouse, 2.8 miles west of, 20 feet south of turnpike, north of house; copper nail in root of large sycamore tree marked " $410 " . . . . .$.

Fairfax Courthouse, 3.5 miles west of, 150 feet east of crossroads, 30 feet south of road, in front of church; iron post stamped "Prim. Trav. Sta. No. 6, Va., 478, 1911" ...................................... $44136^{\circ}-$ Bull. $562-14-2$
344.80

$365.527^{\circ}$

383: 29

446. 776

438. 36

421. 96

406. 74

478. 167 
Fairfax Courthouse, 4.6 miles west of, 130 feet west of road leading to north, 230 feet west of top of hill, north of turnpike, at fence corner; copper nail in cedar stump marked " 437 "

Feet.

434. 34

375.893

300. 60

294. 30 south of turnpike; copper nail in 12-inch white-oak stump marked " 297 "

Pleasant Valley, 0.9 mile east of, 0.3 mile east of road to Sterling, 300 feet west of rise, on nortil side of turnpike; copper nail in 12-inch cedar stump marked " 274 ".

Pleasant Valley, 0.6 mile east of, point on rock at junction of Sterling road with turnpike, marked " 263 "

Pleasant Valley, 100 feet west of post office, in front of residence of M. E. Palmer, in concrete walk, under gate; aluminum tablet stamped " 250 ".

Pleasant Valley, 1.6 miles north of, 100 feet north of road to east to house, 25 feet north of trail to west, 20 feet west of road; copper nail in root of small tree marked " 275 ".

Pleasant Valley, 2.6 miles north of, 15 feet east of road, 100 feet south of road to east; copper nail in root of 12-inch black-oak tree marked " 282 "...

Willard, in northeast angle of crossroads; copper ndil in root of white-oak tree marked " 299.5 ".

Willard, 0.3 mile north of, 40 feet east of road, 30 feet south of public road to east; copper nail in top of 2-foot stump marked " 292 " ............

Willard, 1.5 miles north of, 100 feet north of school, opposite public road west, 15 feet east of road, north of gate; iron post stamped " 276 ".

Sterling, 2.2 miles south of, in southeast angle of junction of roads to Sterling, Pleasant Valley, and Ashburn, 100 feet west of road to Herndon; copper nail in root of 15 -inch wild cherry tree painted " 268 " . .........

Sterling, 1.2 miles south of, 150 feet south of private road west, 250 feet south of house, 200 feet south of bend of road east, 10 feet west of road; copper nail in root of 10 -inch white-oak tree marked " 303 " ..........

From Pleasant Valley south along public road to point near Bull Run.

Pleasant Valley, 1.2 miles south of, 700 feet south of sharp bend to west, 25 feet south of private road; copper nail in root of 8-inch cedar tree west of road, marked " 278 ".

Pleasant Valley, 1.7 miles south of, point on rock in west angle of crossroads, marked " 315.1 ".

Pleasant Valley, 2.7 miles south of, 20 feet north of Braddock road, in northwest angle of road; iron post stamped "Prim. Trav. Sta. No. 5, 280 Va.". .

Pleasant Valley, 3.9 miles south of, 1.2 miles south of Braddock road, 550 feet south of private-road crossing near.house, in edge of timber, east of road, in bend to east; chiseled square on stone marking land line, marked " 250 "

Pleasant Valley, 5.2 miles south of, 2.5 miles south of Braddock road, west of road near bend to west, opposite home of Mrs. C. V. Gheen, in sandstone bowlder; aluminum tablet stamped " 285 "

Pleasant Valley, 6.3 miles south of, 0.4 mile north of Warrenton turnpike, 175 feet north of small stream east, in open field, 20 feet west of road, 2 feet west of ditch, on rock; chiseled square marked " 259 ". . . . . . . . . .

Bull Run, 0.9 mile east of, in southeast angle of crossroads at store; chiseled square on rock, marked " 302 ".
275. 58

280. 286

246. 87 
From point 2.1 miles west of Manassas east along public road to Lee Chapel.

Manassas, 2.1 miles west of, at Rixlew, 35 feet north of Southern Ry, tracks, 20 feet west of road; iron post stamped "Prim. Trav. Sta. No. 4, 237, 1911, Va."

Feet.

Manassas, 0.9 mile west of, north of road, 100 feet east of road north to house; copper nail in root of 33 -inch black-oak tree, marked " 271 "............

Manassas, 100 feet southeast of railroad station, in doorstep of office building; aluminum tablet stamped " 314 "

Manassas, 1 mile east of, 700 feet east of road crossing, opposite bend in road south, 25 feet north of tracks; chiseled square on red sandstone rock, marked " 281 "

Manassas, 3 miles east of, 300 feet east of mouth of small run, north of railroad tracks; chiseled square on rock in cut, marked " 185 "............

Manassas, 4.3 miles east of, 20 feet south of tracks, 11 feet east of public road, 4 feet north of sign post; iron post stamped " 168 "...............

Clifton, 150 feet west of station, 40 feet north of tracks, 20 feet west of road; copper nail in root of aspen tree, marked " 192.4 "....................

Clifton, 1 mile southeast of, at fork of road to Manassas, south of road; copper nail in root of small white-oak tree, marked " 370 ".

Clifton, 1.7 miles southeast of, 250 feet northwest of house, in west angle of crossroads; iron post stamped "Prim. Trav. Sta. No. 3, 324, 1911 Va."...

Clifton, 2.8 miles southeast of, in front of house, north of road, 650 feet east of bend to north; copper nail in root of 18-inch black-oak tree, marked " 331 "

Clifton, 3.3 miles southeast of; center of Fairfax road at crossroads at store, marked " 352 ".

236. 790

268. 39

314. 107

277.79

182. 14

168.276

189.40

366. 92

324.469

328.06

Clifton, 3.8 miles east of, 0.5 mile east of Fairfax road, 220 feet east of small stream, 10 feet north of road; copper nail in 12-inch pine stump, marked " 328 "

Clifton, 4.9 miles east of, .20 feet west of road, in front of house, 50 feet south of road east, 35 feet north of road west; iron post stamped " 403 ".

325.32

403.043

Sideburn, 1.5 miles south of, in front of Bellaire School, in east angle of crossroads; copper nail in root of black-oak tree, marked " 359 ".........

Lee Chapel, 0.8 mile northwest of; 45 feet south of top of hill, west of road; copper nail in root of small pine tree, marked " 402 "................

Lee Chapel, 250 feet southwest of, in northwest angle of crossroads; iron post stamped " 330 "

330. 169

From Lee Chapel north to point near Ilda.

Lee Chapel, 1.7 miles north of, 50 feet northwest of crossroads, 300 feet east of white house; copper nail in top of chestnut stump, marked " 372.2 "..

Burkes station, 0.25 mile west of, 15 feet south of track, 50 feet west of road crossing, 5 feet below level of track, in southeast corner of concrete culvert; aluminum tablet stamped " 262 ".

Burkes, 0.7 mile north of, in northeast corner of crossroads, just at foot of telephone pole; cross on rock, marked " 375.8 "....................

Burkes station, 1.6 miles north of, in northwest corner of north-south road crossing Braddock Road; copper nail in root of pine tree, marked " 371 "..

Ilda, 1.2 miles south of, east of road, 150 feet south of private road, inside of fence; copper nail in root of small pine tree, marked " 328 "...........

370.88

325.33 


\section{HAYMARKET QUADRANGLE.}

[Latitude $38^{\circ} 45^{\prime}-39^{\circ}$; longitude $77^{\circ} 30^{\prime}-77^{\circ} 45^{\prime}$.]

From Bull Run south along public road to point 3 miles northwest of Manassas.

Bull Run, in center of south wall of bridge over, on Warrenton turnpike; iron bolt marked " 184 ".

Feet.

Stonehouse, 300 feet southwest of, 200 feet south of store at crossroads, in east end of north abutment of bridge over Young's Branch; aluminum tablet stamped " 186 ".

Stonehouse, 1 mile south of, in front of house of J. H. Rowzie, 100 feet north of gate, east of road; copper nail in root of 6-inch leaning cedar tree, marked " 241 ".

180. 68

185. 716

Stonehouse, 1.5 miles south of, at road leading to Balls Ford; point on rock, marked " 229.5 "

Manassas, 4.3 miles northwest of, opposite gate on private road, west of public road in bend to west; copper nail in root of small twin white-oak tree, marked " 245 "

Manassas, 3.1 miles northwest of, north of road, opposite road leading to Rixlew, inside of fence near gate; copper nail in root of 10-inch cedar tree, marked " 222 ".

\section{INDIAN HEAD QUADRANGLE. 1}

[Latitude $38^{\circ} 30^{\prime}-38^{\circ} 45^{\prime}$; longitude $77^{\circ}-77^{\circ} 15^{\prime}$.]

From Lee Chapel south along public road to Pohick Creek (double-run line).

Pohick Creek, 3.7 miles northwest of, in southeast corner of crossroads; nail in root of 5 -foot white-oak tree, marked " 317.2 ".

Pohick Creek, 2.6 miles northwest of, 30 feet west of road north to house, 8 feet northeast of road; copper nail in root of 12-inch white-oak tree, marked " 270.6 "

Pohick Creek, 1.7 miles northwest of, 6 feet east of road; copper nail in root of red-oak tree, marked " 200.6 ".

Pohick Creek, in edge of capstone to northwest abutment of old Richmond, Fredericksburg \& Potomac R. R. bridge, just east of new bridge over Pohick Creek in southeast corner of abutment; surface of an offset (C. \& G. S. b. m.)

218. 88

\section{SENECA QUADRANGLE.}

[Latitude $39^{\circ}-39^{\circ} 15^{\prime}$; longitude $77^{\circ} 15^{\prime}-77^{\circ} 30^{\prime}$.]

From Sterling east along public road to Dranesville.

Sterling, in front of schoolhouse, 30 feet north of road to Dranesville, 0.1 mile east of railroad track, in rock; aluminum tablet stamped "Prim. Trav. Sta. No. 1, 314, 1907'".

Sterling, 1.1 miles east of, 300 feet east of bend in road to south, 15 feet north of road; copper nail in root of 15-inch white-oak tree, marked " 321 "

Sterling, 2.1 miles east of, north of road, 150 feet east of small stream running north; copper nail in root of 12 -inch white-oak tree, marked " 290 "..

Sterling, 3.1 miles east of, in northeast angle of crossroads; iron post stamped " $241 "$.

237. 571

1 For elevations in Maryland in this quadrangle see Bulletin 563. 
Dranesville, 0.4 mile west of, north of road, 150 feet northeast of house; copper nail in 10-inch cedar stump, marked " 344 ".

Feet. 340. 76

321. 535 stamped " 322 "

Dranesville, 0.25 mile east of, opposite J. F. Duke's house, south of pike, 12 feet east of 30 -inch oak tree at road fork, in 20 by 8 by 8 inch rock;

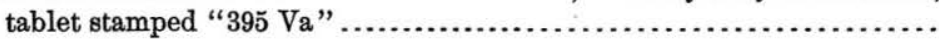

391. 937

From Edwards Ferry southeast to Dranesville.

Mahala, 50 feet north of former post office, north of pike, in big flat rock; tablet stamped " 326 "........................................

Daysville, J. T. Palmer's house, in south wall of west chimney; tablet stamped "Va 314".

\section{WASHINGTON QUADRANGLE. 1}

[Latitude $38^{\circ} 45^{\prime}-39^{\circ}$; longitude $76^{\circ} 45^{\prime}-77^{\circ} 15^{\prime}$.]

From point 0.9 mile west of Tyson Crossroads south along public road to Ilda.

Tyson Crossroads, 0.9 mile west of, 25 feet south of road northeast; copper nail in root of 10 -inch oak tree, marked " 404.7 ".....................

Tyson Crossroads, in northeast angle of, opposite Myers's store; iron post stamped " 483 "

Tyson Crossroads, 1.1 miles southeast of, 15 feet north of culvert, 0.4 mile south of Alexandria turnpike, 10 feet east of public road; copper nail in top of 2 -foot stump, marked " 479 ".

Dunn Loring, 1.7 miles south of, at Merrifield, in northwest angle of crossroads; iron post stamped "Prim. Trav. Sta. No. 1, 362, Va".

Merrifield, 1.4 miles south of, 1,300 feet north of road fork, 100 feet north of small drain, on west side of road; copper nail in root of 12-inch pine tree, marked " 338 "...............................................

Ilda, 0.9 mile north of, on railroad grade, 10 feet east of road; chiseled square on bowlder, marked " 320 ".

Ilda, 0.2 mile east of, opposite road leading to Merrifield, on south side of turnpike; iron post stamped " 374 "

From Alexandria northwest along Alexandria-Leesburg pike to Falls Church.

Alexandria, near middle of sill of northwest window of customhouse, 0.12 meter from extreme west edge of sill, 0.115 meter from extreme edge of

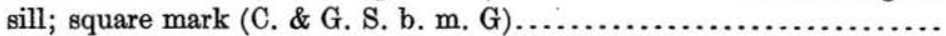

Alexandria, 200 feet east of Union Station, opposite stairway leading to same, on west side of King Street; top of bolt at foot of steel column of Richmond, Fredericksburg \& Potomac R. R. bridge, painted "U. S. B. M. 17 "

Alexandria, 0.94 mile north of customhouse, west end of south curbstone at intersection of Mount Vernon Avenue and King Street; telephone pole painted "U. S. 24 "........................................

Alexandria, 1.4 miles northwest of, east side of road, at foot of southwest brace of standpipe tower; top of bolt, elevation painted on telephone pole near, "U. S. B. M. 140"

Alexandria, 2.9 miles northwest of, 150 feet northwest of Row's store at northwest corner of crossroads; spike in telegraph pole, painted "U. S. B. M. 193 "........................................
401.84

476.475

361.888

374.054

46. 740

1 For elevations in Maryland in this quadrangle see Bulletin 563. 
Alexandria, 4.2 miles northwest of, 250 feet north of small bridge, on west side of road; spike in telegraph pole, painted "U. S. B. M. 133".

Feet.

133.02

252.92

west side of road

Baileys Crossroads, 0.6 mile northwest of, 310 feet southeast of blacksmith shop, 80 feet east of gateway at T lane west; copper nail in sycamore tree, painted "U. S. B. M. 280".

Falls Church, at northwest corner of Broad and Washington streets, on stone

Falls Church, in south face at southwest corner of I. O. O. F. building; aluminum tablet stamped " 338 "

From Alexandria west along Southern Ry. to Burke station.

Alexandria, opposite west end of waiting room at Union-Station; north rail of north track

Seminary station, 140 feet east of road crossing north of track; spike in telegraph pole, painted "U. S. B. M. 38 ".

Cameron Run, 850 feet east of, on top of southwest corner of south abutment of Richmond, Fredericksburg \& Potomac R. R. bridge, about 4 feet above track; aluminum tabled stamped " 54 ".

Cameron Run, south track of bridge over; north rail...................

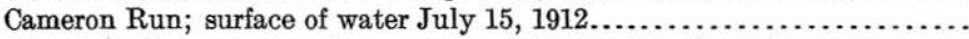

Lincolnia, in front of station; top of north rail of north track..............

Lincolnia, 110 feet west of road crossing, 20 feet south of track; spike in telephone pole, painted "U. S. B. M. 100".

Edsalls station, 0.4 mile east of, on bridge over small creek, south side of north track; bolt in 8 by 8 inch timber 1 foot from west end.

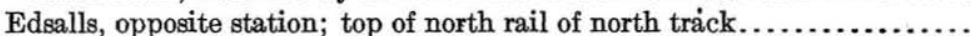

Springfield, 510 feet east of station; west abutment of railroad bridge over Back Lick Run, in top stone at south end; aluminum tablet stamped " 215 "

Springfield, 130 feet east of road crossing, opposite station; top of south rail of north track.

Springfield, 0.8 mile west of, at second-class crossroads; top of north rail, " 250 " painted on telephone pole northeast of crossing..................

Ravensworth, 1 mile east of, east end of steel and timber trestle about 75 feet high, south side; top of bolt, painted "U. S. B. M. 234".

Ravensworth, 450 feet east of station, at road crossing; top of north rail of north track.

Ravensworth, 80 feet northeast of station, 45 feet north of track, 10 feet south of road; spike in telegraph pole, painted "U. S. B. M. 289 ".......

Ravensworth, 0.7 mile west of station, 60 feet northwest of overhead highway bridge, 30 feet north of track; spike in telegraph pole, painted "U.S. B. M. $323 "$.

Burke, in front of station; top of south rail of north track...................

Burke, 0.25 mile west of, 15 feet south of track, 50 feet west of road crossing 5 feet below level of track, in top of southeast corner of concrete culvert; aluminum tablet stamped " 262 ".

From Alexandria north to East Arlington (leveled twice).

Braddock Heights, 950 feet west of station, at northeast corner of crossroads; top of hydrant.

Braddock, in front of station; top of west rail of west track..............

Lloyd, in front of station; top of west rail of west track....................

Delray, 20 feet north of station; top of west rail of west track.
54. 570

54. 5

42. 2

98. 7

99. 66

127. 67

147. 4

215. 155

222. 1

250. 0

233. 66

289. 6

289. 18

322. 80

275. 2

262. 178

50. 30

33. 6

39.3

42.5 
Mount Ida, in front of station; top of west rail of west track..............

St. Asaph, in front of station; top of west rail of east track

St. Elmo, west abutment of Southern Ry. bridge, in top of north end; aluminum tablet stamped " 36 ".

31. 6

Humes Spring, about 500 feet southeast of; copper nail in large oak tree painted "U. S. B. M. 31 ".....................................

St. Elmo, at road fork; spike in telegraph pole, painted "U. S. B. M."....

St. Elmo, 0.6 mile west of, at north end of bridge over Four Mile Run, east side; copper nail in 12 by 12 inch timber.........................

St. Elmo, 1.4 miles north of; top of north end of east wall of culvert.......

East Arlington, 0.1 mile south of, at front entrance to Mount Zion Baptist Church, in top of top step, 0.5 foot north of south end, 0.15 foot west of east edge; chiseled square.

35. 958

30. 82

46. 14

29. 53

50. 28

East Arlington, 60 feet southwest of Hyman's store; chisel mark on top of lone stone.

From Long Bridge west to East Arlington, thence north to Rosslyn.

Long Bridge, west end of south abutment of new bridge, chiseled square (Pennsylvania R. R. b. m. 143a).

20. 56

Clark station on Falls Church Electric Ry.; top of north rail .............

Clark station, 0.3 mile north of, 100 feet north of iron gate in Arlington National Cemetery wall, west side of road; spike in west side of telegraph pole, painted "U. S. B. M. 65 "..

96. 5

"U. S. B. Mil 65 ". 20 feet nor "She stion, 1.1 miles north of, 100 foet north of Arlington station, opposite "Sheridan Gate"; east rail of electric railway

Rosslyn, in west face top of south end of stone doorsill of Arlington National Bank, 0.3 foot east of west edge and 0.5 foot north of south edge; chiseled square.

From Chain Bridge northwest along Leesburg-Georgetown pike to Langley, thence southwest to point 1.1 miles south of Tyson Crossroads.

Chain Bridge, 15 feet southwest of southeast corner of lower half of west abutment; chiseled square.

Chain Bridge, north end of west abutment, top of parapet wall, level with bridge floor, 12 inches southwest of northeast corner, 3.43 feet higher than iron pin in foundation masonry, 4 feet north of bridge seat and on first course below bridge seat; aluminum tablet stamped " 46 ".........

Chain Bridge, 1.4 miles northwest of, at southwest corner of $T$ road south at blacksmith shop, in north root, blazed maple corner tree; copper nail.

Chain Bridge, 1.6 miles northwest of, north side of road, in southwest root of 4 -foot lone maple tree; iron nail.

Chain Bridge, 2.2 miles northwest of, 60 feet west of center of Leighter's entrance drive; copper nail in root of 12-inch cedar tree.

229. 54

235. 53

266. 54

Joseph Leiter's residence, in foundation near northwest corner, 6 feet above ground; bronze tablet stamped " 164.81912 " 1

Langley, south face at southeast corner stone of foundation of Town Hall; aluminum tablet stamped " 275 ".

164. 811

274. 503

McLean, 130 feet northeast of Washington \& Old Dominion Electric Ry. crossing, in north gutter of road, in south side of leaning cherry tree; copper nail. 
McLean, in front of Washington \& Old Dominion Electric Ry. station; top of rail.

Feet.

Lewinsville, 30 feet east of northeast corner of crossroads; copper nail in root of large aspen tree.

Lewinsville, in front stone foundation wall of porch of store of Ánderson Mankin; aluminum tablet (set vertically) stamped " 366 ".

Lewinsville, 0.3 mile south of, at $T$ road west, southeast corner of private road east, on top of stone bracing corner fence post; chiseled square....

Lewinsville, 1 mile southwest of, at summit of road; top of gate rest........

Lewinsville, 1.6 miles southwest of, 0.4 mile east of Alexandria-Leesburg pike, south side of road, southwest of Lorin Magarty's house north of road, in trunk of persimmon tree just east of small wash; copper nail........

Tyson Crossroads, 0.9 mile southeast of, along Alexandria-Leesburg pike, at north corner of $T$ road northeast; top of painted upper staple cemented in 6-foot masonry fence post 3 feet in diameter (fence not yet built)....

Tyson Crossroads, 1.1 miles southeast of, 15 feet north of culvert, 0.4 mile south of Alexandria-Leesburg pike, 10 feet east of public road; copper nail in 2 -foot stump, marked " $479 "$ "...........................

287. 1

368. 56

365.713

332.50

409. 1

375.84

450. 31

476. 475

From point 0.9 mile southeast of Tyson Crossroads southeast along Alexandria-Leesburg pike to Falls Church, thence east along road through Cherrydale to Rosslyn.

West Falls Church, 1.6 miles northwest of, on east side of road, opposite house of James F. Nelson; copper nail in root of 20 -inch sycamore tree..

West Falls Church, 0.6 mile northwest of, at south side of entrance drive to large house, 500 feet west of pike; copper nail in 32-inch locust tree..

West Falls Church, 0.3 mile northwest of, on pike at secondary crossroad, at top of round wooden post 3 feet high, the bottom level with road intersection; copper nail............................................

West Falls Church, in front of post office; top of rail of Washington \& Virginia Electric Ry ...........................................

West Falls Church, in front of Southern Ry. station; top of rail..........

West Falls Church, north corner of West and Broad streets, in stone embedded in root of maple tree; chiseled square.....................

West Falls Church, 0.5 mile southeast of, on Broad Street, on center of top of east end wall of concrete culvert; chiseled square painted " 312 ".....

Falls Church, southeast face of south corner of church, top foundation stone 4 feet above ground; aluminum tablet stamped " 338 "...............

Falls Church, north corner of Broad and Washington streets; top of corner

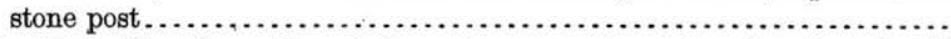

East Falls Church, southwest of crossing, on center of top of north end wall of concrete culvert; chiseled square..............................

Falls Church, in front of Southern Ry. station; top of rail...............

Falls Church, 1.2 miles northeast of station, at crossroads, 67.4 feet northwest of north corner stone and 0.625 foot lower than its highest point; copper nail in root of 3 -foot chestnut tree .........................

Highview Park; doorsill of Kelvey Methodist Church (colored)..........

Highview Park, north face at northwest corner of schoolhouse, in center of top course of foundation brick; chiseled cross painted " 415 U.S. B. M.".

Highview Park, at northeast corner of crossroads, in top of stump of telephone pole behind a used telephone pole and level with road intersection; copper nail. ..........................................

Livingstone Heights, in front of Washington \& Old Dominion Electric Ry.

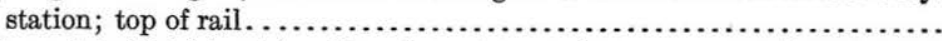

Cherrydale Heights, at junction of street to south at curve; northwest corner of concrete flagstone under pump (not marked).....................

429. 36

398.72

336. 22

311. 90

337. 420

291.02

301.2

374. 63

405. 02

414. 93

403.48

402. 6

364.44 
Cherrydale, 250 feet west of Washington \& Old Dominion Electric Ry. station south side of road, in root on south side of 2-foot oak tree; copper nail.

Feet.

305.40

Cherrydale, in front of Washington \& Old Dominion Electric Ry. station; top of rail.

286. 2

Dominion Heights, in front concrete-faced wall of schoolhouse, 1 foot west of northeast corner, 2.4 feet above ground; aluminum tablet stamped " 267 ".

267.062

Dominion Heights, in front of Washington \& Old Dominion Electric Ry.

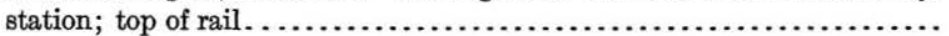

Rosslyn, 1.8 miles west of, west side of Bluemont Division of Washington \& Old Dominion Electric Ry. bridge over highway, south side of highway, on center of concrete end wall of iron culvert; chiseled square painted " 190 "

257.9

189.92

Rosslyn, 1.2 miles west of, 84 feet east of road fork to south, in trunk of leaning cherry tree; copper nail, tree painted "B. M. 223 "..............

Rosslyn, 1 mile west of, at southeast corner of crossroads, on corner stone post 0.8 foot lower than ground at intersection (not marked)...........

Rosslyn, 0.7 mile west of, at iron tank watering trough, on west end of south concrete end wall of iron culvert under electric railway; chiseled square painted " 152 ".

Rosslyn, Arlington National Bank, in west face at northeast corner, in sandstone water table; aluminum tablet stamped " 62 " .................

Rosslyn, Arlington National Bank, on south end of west doorsill; chiseled square.

Boydton, Brookneal, Cahas Mountain, Callands, Chatham, Clarksville, Cloveř, Lynchburg, Moneta, Nathalie, and Virgilina quadrangles.

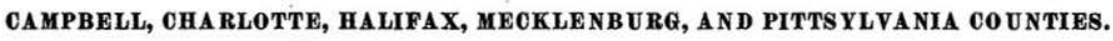

The elevations in the following list result mainly from a line of levels run in 1905 by $\mathrm{A}$. H. Horton, of the Water-Resources branch of the Survey from a bench mark at Clarksville established by the preciselevel party of R.L.Libbey. The linefollows Roanoke River (approximately) from Clarksville to Hurt; thence the railroad via Elba to Rocky Mount, where it is connected with a bench mark also established by Libbey. A spur line extends 14 miles down Roanoke River from Clarksville, and another line extends from Toshes to Deerwood Ford.

Additional work was done in 1908 by E. O. Halbert, in cooperation with the State, in Clarksville, Clover, Nathalie, and Virgilina quadrangles, based on bench marks at Clarksville, Randolph, and Clarkton.

\section{CLARKSVILLE QUADRANGLE.1}

[Latitude $36^{\circ} 30^{\prime}-36^{\circ} 45^{\prime}$; longitude $78^{\circ} 30^{\prime}-78^{\circ} 45^{\prime}$.]

From Clarksville northwest along Roanoke River to Balley's plantation.

Bluestone Creek, at mouth of, 250 feet north of Roanoke River, 120 feet east of Skipwith's (deserted) mill, top of low embankment; iron post stamped " 284 Adj 1903 "................................... 283.550

${ }^{1}$ For precise-level elevations in Clarksville quadrangle see pp. 8-9. 
Abbyville, 1 mile below, in pasture lot of William Russell, 400 feet from river, in top of granite bowlder; aluminum tablet stamped " $290 \mathrm{Adj}$ $1903 "$.

Feet.

Abbyville, 2 miles above, on left bank of Roanoke River, at foot of bluff on McLean's plantation, 100 feet north of an old mill, set vertically in a granite ledge; aluminum tablet stamped " 296 Adj 1903 "............

Abbyville, 5 miles above, on left bank of river, 1,300 feet below mouth of Difficult Creek, which is on right bank of river, set vertically in a rock ledge on Bailey's plantation; aluminum tablet stamped "312 Adj 1903".

289.683

296. 192

311. 639

From Clarksville west along Southern Ry. to point 2 miles west of Nelson.

Clarksville, in southeast corner of west abutment pier at Southern Ry. bridge; aluminum tablet stamped " 288 ".

287.568

Clarksville Junction, in front of station; top of rail.....................

Clarksville Junction, 200 feet west of, at railroad bridge; top of rail. .....

South Clarksville, in front of station; top of rail.....................

South Clarksville, 1.2 miles west of, east end of small cut, sandstone bowlder 15 feet north of track; top marked "G. S. $\square 376$ B. M.".......

South Clarksville, 2.2 miles west of, 300 feet north of track, in south face of chimney of George Day's $1 \frac{1}{2}$-story $\log$ house, 18 inches above ground;

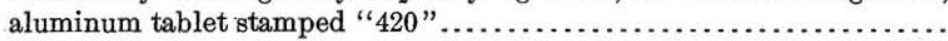

South Clarksville, 3 miles west of, 50 feet north of track, at west end of fill, inside of fence, in base of white-oak tree; spike.

287.8

292.6

357.7

376. 20

419. 574

South Clarksville, 3.4 miles west of, 50 feet north of track, on public road, in root of large white-oak tree; railroad spike. ......................

Buffalo Junction, in front of station; top of rail......................

Buffalo Junction, 1.1 miles west of, 120 feet south of railroad track south of public road, in foot of oak tree; spike.............................

Buffalo Junction, 2 miles west of, 200 feet south of railroad, in north face of chimney of H. T. Arrington's $1 \frac{1}{2}$-story house, 18 inches above ground; aluminum tablet stamped " 471 "..............................

Buffalo Junction, 4.8 miles west of, brick railroad culvert, in top of south head wall; aluminum tablet stamped " 423 "

Nelson, in front of station; top of rail.............................

\section{CLOVER QUADRANGLE.}

[Latitude $36^{\circ} 45^{\prime}-37^{\circ}$; longitude $78^{\circ} 30^{\prime}-78^{\circ} 45^{\prime}$.]

From Difficult Creek northwest along Roanoke River to Clarks Ferry.

Lacks Ferry, 2 miles below, right bank of Roanoke River, 125 feet south of large double gum tree and large double white-oak tree, 250 feet from edge of river, 1 foot above line between properties of Alexander M. Coleman and Charles Wadkins; iron post stamped "315 Adj 1903 ".........

Lacks Ferry, 1,100 feet above, on left bank of river, 50 feet from edge of river, in rock ledge; aluminum tablet stamped " 323 Adj 1903 "........

Beatrice, about 100 feet fron former post office; iron post stamped "479 Adj $1903 "$ ".

Beatrice, 3.4 miles northwest of, road forks at Black Castle schoolhouse; iron post stamped "489 Adj 1903 ".

Randolph, in left abutment downstream side of Southern Ry. bridge across Roanoke River; copper bolt in cement in capstone, stamped "341 Adj 1903 ".

315.265

322.733

479. 368

489. 150

340.657

Clarks Ferry, 0.8 mile north of, in west side, near southwest corner of foundation of T. C. Watkin's house; aluminum tablet stamped "453 Adj $1903 "$ 
From Randolph southwest along Southern Ry. to point 1 mile southwest of Clover.

Randolph, in left abutment downstream side of railroad bridge across Roanoke River; copper bolt in capstone, stamped " 341 "............ Randolph, railroad bridge over Roanoke River; top of rail............. Roanoke River; surface of water under bridge Sept. 30, 1908.......... Clover, in front of station; top of rail..............................

Clover, in face of division wall between Bank of Clover and post office, on west side of Main Street; aluminum tablet stamped " 506 ".

Feet. 340.657

346.1

306

491.8

505. 789

NATHALIE QUADRANGLE.

[Latitude $36^{\circ} 45^{\prime}-37^{\circ}$; longitude $78^{\circ} 45^{\prime}-79^{\circ}$.]

From point near Watkins northwest along Roanoke River to Clarkton.

Watkins, 0.33 mile west of post office, in southwest corner of four corners; iron post stamped " 490 Adj 1903 "...........................

Watkins, 1.2 miles west of, north of road, 100 feet northeast of I. C. Scott's mail box; corner of a stone post 1 foot above ground. . . . . . . . . . . . . . .

Noland, north of road, 85 feet east of post office and store; iron post stamped "503 Adj 1903 "

Coles Ferry, on hill south of, opposite Mr. Stearn's house, on right bank, in large bowlder embedded in ground; aluminum tablet stamped "401 Adj 1903".

Coles Ferry, 3 miles above, on north side of river road, on Bruce's estate near H. C. Gilliland's house; iron post stamped "368 Adj 1903".......

Clarkton, in grass plot between Clark's store and station; iron post stamped " 393 Adj 1903 "............................................

503. 070

${ }^{1} 386.434$

From Houston north along Norfolk \& Western Ry. to Clarkton.

Neathery, in front of station; top of rail. ..........................

Neathery, 0.2 mile north of, 10 feet west of track, in top of west head wall of small stone railway culvert; aluminum tablet stamped " 482 ".........

Neathery, 3.3 miles north of, 10 feet east of track, in top of east head wall of small stone railway culvert; aluminum tablet stamped " 534 "........

Crystal Hill, in front of station; top of rail..........................

Crystal Hill, 1.9 miles north of, 200 feet south of road crossing, 10 feet west of track, in top of west head wall at small railway culvert; aluminum

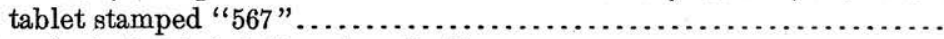

Lennig, in front of station; top of rail............................

Lennig, 2.3 miles north of, 20 feet west of track, in top of west head wall of small railway culvert; aluminum tablet stamped " 531 "..............

Nathalie, in front of station; top of rail............................

Nathalie, 1.8 miles north of, top of west head wall of small railway culvert; aluminum tablet stamped " 432 ".............................

533. 801

564.3

566. 731

576.7

530.543

524.5

431. 738

From Scottsburg northeast along Southern Ry. to point near Clover.

Clover, 5 miles south of, 2,100 feet north of overhead bridge, top of west head wall of stone railway culvert; aluminum tablet stamped " 375 "...

Clover, 2.7 miles south of, top of east catch wall of south abutment of railway bridge; aluminum tablet stamped " 363 ". . . . . . . . . . . . . . . . . . . 
IYNCHBURG 30' QUADRANGLE (embracing Gladys and Leesville 15' quadrangles).

[Latitude $37^{\circ}-37^{\circ} 30^{\prime}$; longitude $79^{\circ}-79^{\circ} 30^{\prime}$.]

From Perth west along Roanoke River to Hurt.

McKeever Ferry, about 0.3 mile east of road forks, 75 feet south of T. L. Rudder's house, in a 3-foot turkey-oak tree; aluminum tablet stamped "545 Adj 1903".

Green Hill, at road forks to ferry; iron post stamped "510 Adj 1903 ".....

Cedar Forest, 150 feet east of Mrs. E. Hendrick's store, at corner of fence; iron post stamped " 540 Adj 1903 "

Cedar Forest, 3 miles northwest of, south of road, opposite Blackstock schoolhouse, in 3-foot oak tree; aluminum tablet stamped "702 Adj $1903 "$ ".

Feet.

545.008

509. 961

539. 844

701. 952

703. 894

718. 491

Level Run, north of road opposite post office, in 2-foot oak tree; aluminum tablet stamped "719 Adj 1903 ".

Level Run, 3 miles northwest of, about 200 feet south of Sandy Coleman's house, on Hubbard's plantation, in rock-ledge west of road; aluminum tablet stamped "694 Adj 1903"...............................

Grit, in road in front of A. M. Peak's house, in south side of a 4-foot whiteoak tree; aluminum tablet stamped "784 Adj 1903".

Grit, 2 miles northwest of, in forks of road at top of hill above mill creek ford; iron post stamped "728 Adj 1903".

Hurt, 0.5 mile east of, in a $2 \frac{1}{2}$-foot oak tree at top of hill west of Reed Creek, south of road on Dr. Adams's plantation; aluminum tablet stamped “710 Adj 1903".

Hurt, in right abutment (upstream side) of Southern Ry. bridge; top of southwest bolt fastening upstream and post seat to abutment............

From Hurt south along Southern Ry. to point near Elba.

Hurt, in ground at east post of "Welcome" gate at Hurt's plantation; iron post stamped "559 Adj 1903 ".

Motley, 2 miles north of, on west side of railroad about 30 feet from track, between mileposts 201 and 202, in a 4 -foot oak tree; aluminum tablet stamped "658 Adj 1903".

Motley, in ground at G. W. Shuler's store, at east corner; iron post stamped " 771 Adj 1903".

Sycamore, 0.25 mile south of station, in north side of north chimney of G. W. Ramsey's house; aluminum tablet stamped "751 Adj 1903".

Elba, 3 miles north of, on west side of road from Elba to Sycamore, 600 feet south of railroad crossing, on east side of track, directly opposite Walton's mail box; iron post stamped " 8531903 ".........................

Elba, 2 miles north of, east of railroad, near first sign "Station 1 mile" referring to Elba, in a tree; aluminum tablet stamped "864 Adj 1903 "...

CHATHAM QUADRANGLE.

[Latitude $36^{\circ} 45^{\prime}-37^{\circ}$; longitude $79^{\circ} 15^{\prime}-79^{\circ} 30^{\prime}$.]

From Elba west along Southern Ry. to Toshes.

Elba, 150 feet north of Mrs. Shelton's store, at southeast corner of Mrs. E. W. Shelton's ground; iron post stamped " 844 Adj 1903 "..................

Farmers, at northwest corner of E. H. L. Farmer's house, east of railroad, 60 feet from track; iron post stamped " 1044 Adj 1903 "...............

Pittsville, 1 mile east of, in ground at road forks; iron post stamped " 965 Adj 1903" 
Toshes, 1,500 feet east of, in railroad cut east of Toshes, 140 feet west of west end of trestle across Buck Branch, tributary to Fryingpan Creek, south of railroad, at east end of rock ledge; aluminum tablet stamped " 681 Adj 1903".

Toshes, 125 feet south of post office and store (property of C. S. Bennett), 25 feet east of scale house, in rock ledge; aluminum tablet stamped " 695 Adj 1903"

81.203

695.135

MONETA QUADRANGLE.

[Latitude $37^{\circ}-37^{\circ} 15^{\prime}$; longitude $79^{\circ} 30^{\prime}-79^{\circ} 45^{\prime}$.]

From Toshes north along highways to Deerwood Ford (spur line).

Pig River, 1 mile south of bridge across, south of road, 0.25 mile above Graves's new dam on Pig River, in 4-foot white-oak tree; aluminum tablet stamped " 625 Adj 1903 ".

624.38

Menla, about 1.5 miles southeast of, directly east of Frank Graves's house, 50 feet below his mail box, in east side of a 3 -foot oak tree; aluminum tablet stamped "734 Adj 1903".

Menla, in front of J. T. Robinson's house, west of road, on east side of 4-foot oak tree; aluminum tablet stamped " 862 Adj 1903 ".

Deerwood Ford, on Roanoke River, in northeast stone chimney of G. L. English's house; aluminum tablet stamped "618 Adj 1903 "............

Deerwood Ford, on sycamore tree on left bank of Roanoke River near transit station 2681+15; Virginia Ry. bench mark.....................

CALLANDS QUADRANGLE.

[Latitude $36^{\circ} 45^{\prime}-37^{\circ}$; longitude $79^{\circ} 30^{\prime}-79^{\circ} 45^{\prime}$.]

From Toshes west along Southern Ry. to Glade Hill.

Sandy Level, in quartz ledge near road crossing of Reddies Creek; aluminum tablet stamped " 660 Adj 1903 "

659.953

Ajax, 12 feet south of track, 450 feet west of crossing, east side of ledge of rock; aluminum tablet stamped " 873 Adj 1903 "......................

Penhook, 500 feet west of station, 8 feet south of track, in rock ledge; aluminum tablet stamped " 982 Adj 1903 "..........................

Novelty, in ground at angle of store (former post office); iron post stamped

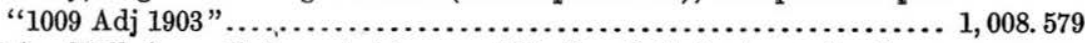

Union Hall, in north face of chimney of Dudley \& Co.'s store; aluminum tablet stamped " 1006 Adj 1903 "............................. 1, 005. 357

Glade Hill, 1.5 miles east of, in east side of south chimney of Mrs. Matilda Bird's house, 350 feet north of track; aluminum tablet stamped "1008

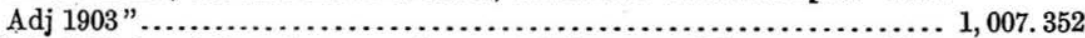

Glade Hill, in a 3-foot chestnut oak tree, 100 feet east of former post office, 65 feet south of track; aluminum tablet stamped "1070 Adj 1908"..... 1, 069.611

\section{CAHAS MOUNTAIN QUADRANGLE.}

[Latitude $37^{\circ}-37^{\circ} 15^{\prime}$; longitude $79^{\circ} 45^{\prime}-80^{\circ}$.]

From Glade Hill west along Southern Ry. to Rocky Mount.

Redwood, 2 miles east of, 125 feet north of track on Jas. O. Perdies's farm, 30 feet west of west end of second trestle west of Glade Hill, on left bank of small branch, in lower of two small rock ledges; aluminum tablet stamped " 1060 Adj 1903 ".

981.591

Redwood, in small rock ledge in front of Perdies Bros.' store; aluminum tablet stamped "1178 Adj 1903 ". ............................ 1, 177.906

Redwood, about 0.5 mile west of, 300 feet west of railroad crossing, 30 feet south of track, in east end of a large quartz bowlder north of road; aluminum tablet stamped "1138 Adj 1903 ". 
Rocky Mount, 2.5 miles east of, 1,200 feet west of milepost 34, 75 feet west of railroad crossing, 9 feet south of center of track; iron post stamped

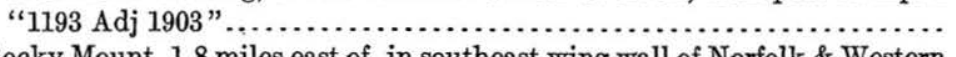

Rocky Mount, 1.8 miles east of, in southeast wing wall of Norfolk \& Western Ry. concrete culvert 1828 , about 700 feet northeast of sign " 1 mile to station;" aluminum tablet stamped "1106 Adj 1903"

\section{BOYDTON QUADRANGLE.}

[Latitude $36^{\circ} 30^{\prime}-36^{\circ} 45^{\prime}$; longitude $78^{\circ} 15^{\prime}-78^{\circ} 30^{\prime}$.]

From Clarksville east 14 miles down Roanoke River to Taylors Ferry (double spur line).

Clarksville, 2.5 miles below, on right bank of river on C. S. Hito's plantation, about 340 feet from bank of river, in granite ledge on left bank of a small ditch; aluminum tablet stamped " 273 Adj 1903 ".

273.007

Clarksville, 7 miles below, opposite J. T. Lewis's plantation; opposite lower end of Finches Island, in granite ledge projecting from left bank of river; aluminum tablet stamped " 250 Adj 1903 "

$1,106.274$

Island Creek, 215 feet from right bank, 300 feet from river, in a granite ledge on James Bulloch's plantation; aluminum tablet stamped "259 Adj 1903"

Eagle Point, 1,500 feet east of ruins of mill, at foot of slope, 100 feet below Hospital Spring on Dr. Wimbish's plantation, in granite ledge; aluminum tablet stamped " 239 Adj 1903 "

\section{BROOKNEAL QUADRANGLE.}

[Latitude $37^{\circ}-37^{\circ} 15^{\prime}$; longitude $78^{\circ} 45^{\prime}-79^{\circ}$.]

From Brookneal to Perth.

Brookneal, on east side of road to ferry, nearly opposite May's cash store, about 75 feet north of Baptist Church; iron post stamped " 564 Adj 1903"

Note.-Permission to destroy this b. m. was granted Feb. 25, 1913.

Brookneal, on William Scott's plantation, 135 feet northwest of center of road to ferry, 50 feet from low-ground cornfield, about 350 feet north from ferryman's house at ferry, in rock ledge flush with ground; aluminum tablet stamped "388 Adj 1903".

Brookneal, 2.3 miles southwest of, about 20 feet from northwest corner of Hickory Road Church, in an 18-inch oak tree; aluminum tablet stamped "599 Adj 1903".

Perth, 225 feet northeast of store and former post office, south of road, on W. H. and J. L. Glass's property; iron post stamped " 612 Adj 1903"...

564.155

388.000

599.170

611.907

\section{VIRGILINA QUADRANGLE.}

[Latitude $36^{\circ} 30^{\prime}-36^{\circ} 45^{\prime}$; longitude $78^{\circ} 45^{\prime}-79^{\circ}$.]

From Virgilina west along Southern Ry. to Denniston, thence north along Norfolk \& Western Ry. to Houston.

Virgilina, in front of station; top of rail.

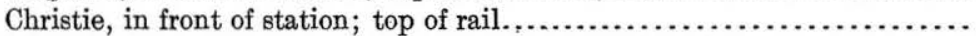

Mayo (3.8 miles west of Christie), 300 feet east of station, top of east head wall of concrete railway culvert; aluminum tablet stamped " 346 "'...... Mayo, in front of station; top of rail.............................. Mayo, 1.9 miles west of, in southwest corner of east abutment of railway bridge over Hyco Creek; aluminum tablet stamped " 336 ".

Denniston, 50 feet north of Norfolk \& Western Ry. station, in top of east head wall of small concrete railway culvert; aluminum tablet stamped " 409 ". 
Cluster Springs, 300 feet west of station, in front (brick) wall of Traynham Bros.' store; aluminum tablet stamped " 499 ".

Feet. 499. 446 493. 3

339.249

336. 6

302

330.976

334.4

447.153

385.6

380.827

333.4

318. 117

359.2

331.421

352.8

South Boston, in front of station; top of rail..........................

Wolftrap, 1.8 miles south of, 800 feet south of milepost 34 , in top of southeast corner of east head wall of stone railway culvert; aluminum tablet stamped " 318 ".

Wolftrap, in front of station; top of rail

Scottsburg, 1.7 miles south of, 10 feet west of track, 300 feet north of whistle post, in top of west head wall of small concrete railway culvert; aluminum tablet stamped " 331 ".

Scottsburg, in front of station; top of rail.

Bonsacks, Craigs Creek, Eagle Rock, and Natural Bridge quadrangles. BOTETOURT, CRAIG, AND ROCKBRIDGE COUNTIES.

The elevations in the following list were determined by primary leveling and accord with Bulletin 434.

The leveling was done in Bonsacks and Natural Bridge quadrangles in 1905 by T. A. Green; in Craigs Creek quadrangle in 1907 by R. S. Deemer and in 1913 by H. S. Senseney; and in Eagle Rock quadrangle in 1905 by Green, in 1907 by Deemer, and in 1913 by Senseney.

\section{BONSACKS QUADRANGLE.}

[Latitude $37^{\circ} 15^{\prime}-37^{\circ} 30^{\prime}$; longitude $79^{\circ} 45^{\prime}-80^{\circ}$.]

\section{At Fincastle.}

Fincastle, southeast of courthouse, outside fence; top of cornerstone, telephone pole is marked "U. S. B. M. 1258.5" ...................... 1, 258.07

Fincastle, south side of Botetourt County courthouse, 10 feet west of front entrance, in stone step; aluminum tablet...................... 1, 256. 696

Fincastle, 0.4 mile west of, main crossroad, west of four corners; nail in hub on cedar tree, marked "U. S. T. P. 1275 ".................... 1, 274.89

\section{CRAIGS CREEK QUADRANGLE.}

[Latitude $37^{\circ} 30^{\prime}-37^{\circ} 45^{\prime}$; longitude $80^{\circ}-80^{\circ} 15^{\prime}$.]

From Hebron Church north along Craig Valley R. R. to Given.

Hebron Church, at road leading southeast; paint spot on stone, marked

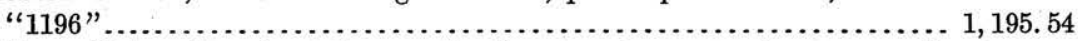

Hebron Union Church, 1 foot south of east entrance to, in stone wall; aluminum tablet stamped " 1192 "........................... 1, 191. 387 
Hebron Church, 0.1 mile north of, at road north; paint spot on rock, marked Feet.

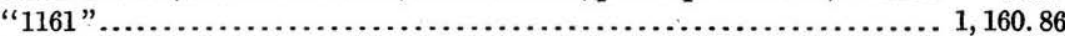

Hebron Church, 0.2 mile north of, road at hilltop, house to west, marked

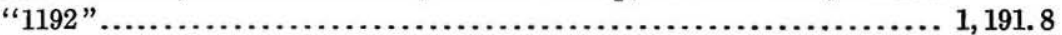

Hebron Church, 0.4 mile north of, at road forks, west side of road; on root of tree marked " 1196 " .................................... 1, 195.29

Hebron Church, 1.5 miles north of, at road leading northwest, south side of road; paint spot on large stone, marked " 1178 " .................1,177.74

Given, 1 mile south of, road at bend to north....................... 1, 209.07

Given, 0.9 mile south of, railroad crossing; center of southwest rail, marked " 1286 ".

$1,286.13$

Given, on northeast end of cattle stop; bolt marked " 1288 "............ 1, 287.36

Given, 0.42 mile northeast of, west side of track, on first course of stone, at northwest corner of culvert; aluminum tablet stamped " 1274 ".

$1,274.096$

EAGLE ROCK QUADRANGLE.

[Latitude $37^{\circ} 30^{\prime}-37^{\circ} 45^{\prime}$; longitude $79^{\circ} 45^{\prime}-80^{\circ}$.

\section{From Springwood southwest along highway to Fincastle.}

Springwood, in center of bridge; nail (elevation of water surface in James

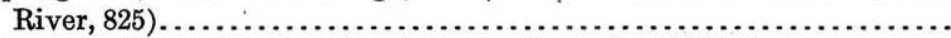

Forks at mill, center of road; point on rock, marked " 875 ".............

Bridge over stream (water surface $=888$ ).

874.63

899.64

Springwood, 1.2 miles west of, on ledge of rocks, north side of road; cut square marked "U. S. B. M. 1000 "

999.58

Springwood, 2 miles west of, at Shark's store, on south side of road, just east of crossroads, on ledge of rock; cut square marked "U.S. B.M. 1059". 1, 058.81

Springwood, 3 miles southwest of, on south side of road, just east of main forks, on ledge; cut square marked "U. S. B. M. 1120 ".............. 1, 119.98

Road to right through gate, south side of road; point on rock, marked " 1158 ".................................................. 1, 157. 31

Springwood, 4.6 miles southwest of, at schoolhouse, on south side of road, 50 feet east of main forks, in hub on 4 -foot oak tree; nail marked "U. S. B. M. 1235 "

Springwood, 5.1 miles southwest of, in northwest corner of stone foundation of house owned by C. C. Burch, on north side; aluminum tablet.... 1, 284.070

Springwood, 6.5 miles southwest of, on north side of road, 330 feet west of main forks, on ledge of limestone rock; square cut marked "U.S.B.M.

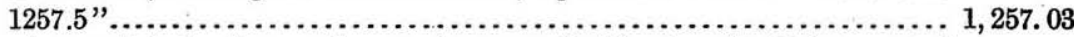

Springwood, 7.2 miles southwest of, on north side of road, 20 feet east of stream crossing, on limestone rock; square cut marked "U.S. B.M.1179". 1, 178.51

Springwood, 7.9 miles southwest of, on north side of road, 150 feet west of large branch at private crossroads; cross on top of rockmarked "U.S. B.M. 1073 ".

Fincastle, forks of road, at east edge of town, near fence; point of rock marked " 1233 ".......................................... 1,232.87

Fincastle, near forks, at foot of hill; point on curbstone marked "1195"... 1, 194.99

From point near Fincastle northwest along highway to point near Hebron Church.

Fincastle, 1.1 miles northwest of, on west side of road, just south of secondclass road to left, through gate, on ledge of limestone rock; square cut marked "U. S. B. M. 1225 "................................. 1, 224. 72

"Grove Hill," at private road leading to; point on rock marked "1124".. 1, 123.61 Catawba Creek; water surface $\ldots \ldots \ldots \ldots \ldots \ldots \ldots \ldots \ldots \ldots \ldots \ldots \ldots \ldots, 0 . \ldots \ldots, 38$ 
Fincastle, 1.8 miles northwest of, on south side of road, just west of main forks, at small bridge; square cut on limestone rock, tree marked

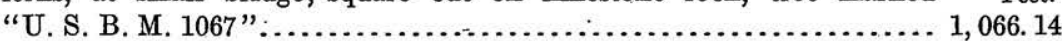

Fincastle, 3.2 miles northwest of, on east side of road, 30 feet northwest of house, in hub on 2-foot oak tree; nail marked "U. S. B. M. 1232"...... 1, 231. 63

North fork; water surface marked " $1200 "$ "....................... 1, 199. 21

Poorhouse Hollow, at mouth of, on north side of creek, just east of secondclass road, on limestone rock; square cut marked "U. S. B. M. 1256".. 1; 255. 521

Fincastle, 4.4 miles northwest of, at mouth of "Poorhouse Hollow," 650 feet west of main forks, north of north fork of Catawba Creek, just east of second-class road, in bench of limestone rock; aluminum tablet stamped " 1256 " (as reset in 1913)...................................... 1,255.345

Fincastle, 5.3 miles northwest of, on north side of road, just west of forks at ford, in hub on 3-foot sycamore tree; nail marked "U.S. B.M. 1346".. 1, 345. 50

Fincastle, 5.7 miTes northwest of, at foot of mountain, on west end of south abutment of bridge over stream; chiseled square marked "U. S. B. M.

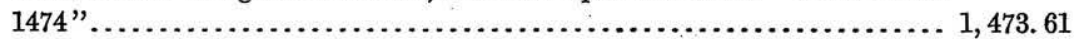

Fincastle, 6.2 miles northwest of, on east side of gully, in hub on 1-foot oak tree; nail marked "U. S. B. M. 1624"........................... 1, 623.09

Price's Mountain Gap, at center of road; marked " 1961 "............. 1, 960.41

Fincastle, 7 miles northwest of, at Craig-Botetourt county-line crossing, at gap on Price's Mountain, on county-line rock, on south side of road; paint spot marked "U. S. B. M. 1959"......................... 1,958.963

Fincastle, 7.6 miles northwest of, on rock on south side of road, 100 feet west of gully; square cut marked "U. S. B. M. 1662 "................. 1, 661. 44

Fincastle, 7.7 miles northwest of, road at sharp turn to north; painted on rock, marked " 1617 " ..................................... 1, 617.19

Fincastle, 8.1 miles northwest of, road at turn to north; painted on rock, marked " 1385 ".......................................... 1, 385.17

Fincastle , 8.3 miles northwest of, north side of road, 50 feet east of house on south side of road, on large stone; paint spot marked " 1334 "....... 1, 333.69

Fincastle, 8.9 miles northwest of, on top of hill, at house on north side of

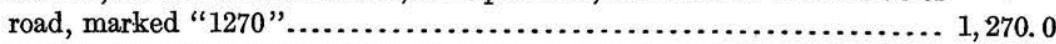

Fincastle, 9.1 miles northwest of, on northwest abutment of wagon bridge; paint spot marked " 1226 "..................................... 1,225.92

Fincastle, 9.2 miles northwest of; bridge floor marked " 1211 "......... 1,210.8

From Eagle Rock west along Craig Valley Branch of Chesapeake \& Ohio Ry. to Given.

Eagle Rock, 0.2 mile west of, in northwest abutment of wagon bridge over James River; aluminum tablet stamped " 934 "

Eagle Rock, 0.7 mile west of, on railroad bridge over James River; top of crossties.

James River; surface of water under bridge Aug. 22, 1913

934. 550

943.2

908.9

Bessemer, at Garges's sawmill, southwest corner of cattle guard; temporary bench mark.

Eagle Rock, 1.9 miles west of, west end of railroad bridge over Craig Creek, north side of track; bolt (30.2 feet above water) Aug. 22, 1913.

942.55

Eagle Rock, 2.9 miles west of, 0.5 mile west of road crossing, 900 feet west of milepost marked "N. C. 25, E. M. 2," south side of track, in culvert; bronze tablet stamped " 984 ".

946.92

Pinnacle, 2.2 miles east of, 0.9 mile west of milepost marked "E. M. 3, N. C. 26 ," north side of track, in northwest corner of culvert; aluminum tablet stamped " 988 " (not found in 1913) 
Eagle Rock, 5.4 miles west of, 100 feet west of cut at the "Pinnacles," on Feet. northeast corner of cattle guard; bolt......................... 1,096.00

Parr post office, 1.4 miles east of, west side of track, southwest corner of culvert; aluminum tablet stamped " 1039 " restamped " 1036 "........... 1, 036.030

Parr post office, 2.1 miles east of, at road crossing, northwest corner of cattle

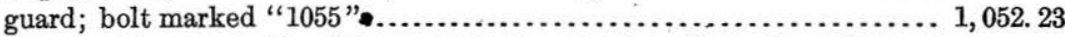

Parr post office, west side of track, 10 feet north of small creek; paint spot

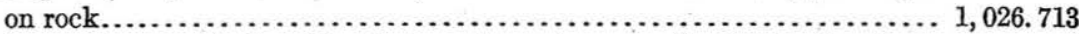

Hipes station, west side of track, in southwest corner of culvert; aluminum tablet stamped "1025." (A Deemers bench mark; could not be found in 1913)........................................ 1, 022.556 or $1,023.058$

Hipes station, 400 feet west of south side of track, in culvert; bronze tablet stamped " 1033 ".

Hipes station, 1.1 miles west of, railroad bridge over Craig Creek, southwest corner; bolt............................................. 1, 051.39

Old sawmill, at road crossing; top of rail.......................... 1, 081.1

Hipes station, 1.7 miles west of, northeast corner of cattle guard; bolt..... 1, 082.85

Schoolhouse, at crossing west of; top of rail......................... 1, 067.2

Surber, in front of station; top of rail.............................. 1,066.5

Surber, 300 feet south of station, west side of track, in culvert; aluminum tablet stamped "1060" restamped "1057"......................... 1, 057.221

Surber, 1.9 miles west of, at road crossing, northeast corner of cattle guard; bolt................................................. 1, 118.40

Oriskany, at road crossing; top of rail.......................... 1, 142.8

Oriskany, 500 feet west of station, south side of track, in culvert; aluminum tablet stamped " 1130 " restamped " 1127 "

Given, 0.4 mile east of, north side of track, in culvert; aluminum tablet stamped " 1274 ".......................................... 1, 274. 096

From point 1.9 miles west of Eagle Rock northwest along highway to Strom, thence south to Parr.

Bessemer, 4.5 miles west of, on road to Strom post office, 25 feet west of forks, in root of tree; copper nail.

958. 62

Stron. post office, 300 feet east of, west side of road, in large bowlder; aluminum tablet stamped " 1023 ".

East side of road, 500 feet south of house, in root of tree; nail.

NATURAL BRIDGE QUADRANGLE.

[Latitude $37^{\circ} 30^{\prime}-37^{\circ} 45^{\prime}$; longitude $79^{\circ} 30^{\prime}-79^{\circ} 45^{\prime}$.]

From Buchanan northeast along Chesapeake \& Ohlo Ry. to Gilmore Mills.

Buchanan, 3.3 miles northeast of, 200 feet east of house occupied by Charles Stinnett, in ledge of rock; aluminum tablet.

Note.-Permission to destroy this b. m. was granted June 10, 1913.

Dillon, in front of station, main track; top of north rail.

Indian Rock, in southeast corner of west abutment at south side of railway bridge over Whistle Creek; aluminum tablet.

794. 164

Indian Rock, in front of station; top of north rail of main track ..........

Rocky Point, in southeast corner of east abutment of railroad bridge over

Roaring Run; aluminum tablet.

Alpine, in front of station; top of south rail............................

771.149

773.6

Gilmore Mills, in front of station; top of north rail.

751.1 
From Gilmore Mills north along highway via Natural Bridge and Longwood to Murat.

Natural Bridge, on north side of bridge, in rock standing in inclosure; Feet. aluminum tablet stamped " 1150 Adj 1903 "...................... 1, 149.661

Natural Bridge, 2.6 miles northeast of, at main road forks 1.5 miles southwest of Fancy Hill post office, in rock north of road just east of forks; aluminum tablet stamped " 1231 Adj 1903"...................... 1, 231. 014

Longwood, 1 mile northeast of, in fifth brick from west at southwest corner (south side) of Seceder Church, in fourth course of bricks above foundation; aluminum tablet stamped "1179 Adj 1903".

Longwood, 3.8 miles northeast of, 75 feet south of stream crossing, in large rock; aluminum tablet stamped " 1251 Adj 1903 "................... 1, 250.677

Murat, in southeast corner of south abutment of south end of highway bridge over Buffalo Creek; aluminum tablet stamped "1021 Adj 1903" ........ 1, 021.262

From Buchanan north along highways via Rapps Mill to Murat.

Buchanan, 3 miles north of, on Mr. Peachin's place, in sandstone 75 feet north of house occupied by Charles Miller; aluminum tablet......... 1, 161.841

Buchanan, 7 miles north of, at main road forks just west of Dunkard Church in rock on east side of road just north of forks; aluminum tablet stamped "1597 Adj 1903"

Rapps Mill, 50 feet southeast of, in front yard of James B. Rapp, in sandstone; aluminum tablet stamped "1497 Adj 1903 "................ 1,496.550

Rapps Mill, 3.2 miles northeast of, 210 feet north of main forks, in ledge of rock east of road; aluminum tablet stamped "1277 Adj 1903"......... 1, 277. 262

Murat, 3.5 miles west of, 6.2 miles northeast of Rapps Mill, at iron wagon bridge over South Buffalo Creek, on south side at southeast corner of east abutment; aluminum tablet stamped "1150 Adj 1903"............... 1, 149.707

Up North Buffalo Creek via Oakdale and over Biggs Mountain to Dagger Springs and Gala.1

Oakdale, 1.5 miles southwest of, north of road, in rock 30 feet west of main road forks; aluminum tablet stamped " 1307 Adj 1903"............... 1, 308. 004

Oakdale, 6 miles southwest of, at gap at head of North Buffalo and Mill creeks, in large bowlder; aluminum tablet stamped " 2179 Adj 1903"... 2, 179. 680 .

Oakdale, 9.8 miles southwest of, at crossroads, 2 miles southeast of Dagger Springs, directly north of four corners, in rock north of road; aluminum tablet stamped "1392 Adj 1903 "

$1,392.463$

Antietam quadrangle.

LOUDOUN COUNTY.

The elevations in the following list are based on precise-level lines of the Coast and Geodetic Survey and the Baltimore \& Ohio Railroad. The leveling in Antietam quadrangle was done in 1907 by W. R. Winstead.

Elevations in Maryland appear in Bulletin 563; those in West Virginia in Bulletin 399.

\footnotetext{
${ }^{1}$ An arbitrary adjustment of 1 foot was made between starting point and first bench mark of this line.
} 
ANTIETAM QUADRANGLE.

[Latitude $39^{\circ} 15^{\prime}-39^{\circ} 30^{\prime}$; longitude $77^{\circ} 30^{\prime}-77^{\circ} 45^{\prime}$.]

From Point of Rocks southwest along highway to Taylorstown, thence northwest to Harpers Ferry.

Taylorstown, 0.1 mile west of post office, in center of south end of pillar at west end of iron bridge over Catoctin Creek; aluminum tablet stamped "Maryland 272 Adj".

Feet.

272.000

Taylorstown, 2.6 miles northwest of, 50 feet east of road fork south, near short bend in road to north, 15 feet west of barn, on top of stone; chiseled square marked " 479.6 U. S. B. M.".............................

Lovettsville, in front face of post office at G. F. Eamich's store, east side of door, between door and window; aluminum tablet stamped "Md 507 Adj".

Lovettsville, 3.4 miles northwest of, 0.1 mile north of road fork, 150 feet north of second-class fork west, 1,000 feet east of house, 8 feet east of road by fence bars, in west side of large sandstone; aluminum tablet stamped "Md 471 Adj".

Lovettsville, 7.1 miles northwest of, 0.4 mile west of sawmill, about 0.2 mile west of old house, at spring on left of road in front of house, 12 feet north of road between road and river, in top of large native rock; aluminum tablet stamped "Adj 254 "...................................

Lovettsville, 8.7 miles northwest of, in north side at center of bridge over Shenandoah River at Harpers Ferry; nail marked " 281 ". . . . . . . . .

506.800

470.629

253.401

281. 19

From point 1 mile east of Harpers Ferry south to Neersville.

Neersville, 300 feet north of road forks, 0.2 mile north of former post office, in northeast corner of schoolhouse; aluminum tablet stamped "615 Adj".

Bramwell quadrangle.

[Latitude $37^{\circ} 15^{\prime}-37^{\circ} 30^{\prime}$; longitude $81^{\circ} 15^{\prime}-81^{\circ} 30^{\prime}$.]

TAZE WELL COUNTY.

The elevations in the following list are based on the height of the permanent bench mark at Graham, established by precise leveling in 1909. The leveling was done by T. A. Green in 1909. Elevations in this quadrangle in West Virginia can be found in Bulletin 477.

From divide at head of Abbs Valley southwest to Smith store, thence north to State line (part of adjusted circuit).

Smith store, 350 feet south of forks, 75 feet east of road, 200 feet west of Mrs.

W. T. Harrison's barn, on west side of running stream, in sandstone; alu- Feet. minum tablet stamped " $2598 \mathrm{Va} 1909$ "......................... 2, 597.895

From State line southeast along Norfolk \& Western Ry. to Graham.

Virginia-West Virginia State line, railway crossing; top of rail. ........ 2, 309.4

Flattop, 0.8 mile east of, on rock 40 feet east of milepost 370 ; chiseled square. $2,321.20$

Falls Mills, in front of station; top of rail . . . . . . . . .

Falls Mills, 1.5 miles east of, 500 feet west of milepost 368, north end of east

abutment of railroad bridge 840 ; aluminum tablet stamped " 2348 "..... 2, 347.640

Falls Mills, 2.8 miles east of, at old sawmill, 100 feet east of road crossing on

north end of west abutment of iron railroad bridge 835 ; chiseled square.. 2, 370.10

Graham, in front of signal tower; top of rail . . . . . . . . . . . . . . . 
Graham, at northwest corner of station platform, on granite curbing; chis- Feet. eled square................................................. 2, 393.46

Graham, on west side of front entrance to Bank of Graham, third step above pavement; aluminum tablet stamped " 2389 "....................... 2, 389. 450

From State line southwest along Norfolk \& Western Ry. to Pocahontas (mean of two lines).

Pocahontas, in front of station; top of rail..................... 318.8

Pocahontas, on west side of front entrance to Bank of Pocahontas, in first step above pavement; aluminum tablet stamped " 2320 Va 1909 "....... 2, 320.057

From State line near Nemours, W. Va., southwest up Abbs Valley to point near divide (part of adjusted circuit).

Nemours, 1.1 miles southwest of, east of road, 20 feet west of gate, on limestone; chiseled square marked “U. S. B. M. 2334" ................. 2, 330. 78

Nemours, 1.9 miles sonthwest of, west of road, at top of knoll, on limestone; chiseled square marked "U. S. B. M. 2395 ".................... 2, 395. 18

Nemours, 2.8 miles southwest of, at road forks, 300 feet east of large red barn, 30 feet north of gate east of road, in limestone; aluminum tablet stamped " $2443 \mathrm{Va} 1909$ ".

Nemours, 4 miles southwest of, 300 feet south of Mr. Browning's house, west of road, at sharp bend, on limestone ledge; chiseled square marked "U. S. B. M. 2411 "....................................... 2, 411.52

Nemours, 4.9 miles southwest of, at junction with main road running east, 15 feet west of telephone pole at northeast corner of road junction, on limestone; chiseled square marked "U. S. B. M. 2441 " ............. 2, 441. 27

Nemours, 6.4 miles southwest of, south of road, on top of hill, north of fence, in sandstone bowlder; aluminum tablet stamped " 2523 Va 1909".. 2, 522.908

Nemours, 7.5 miles southwest of, 0.3 mile southwest of J. G. Bailey's house north of road, on limestone outcrop; chiseled square marked "U. S. B. M.

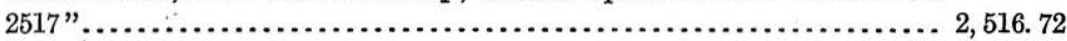

Nemours, 8.3 miles southwest of, at junction with road running northwest through gate, point on limestone, 5 feet north of W. A. Barrett's mail box, at southeast corner of road junction; mail box marked "U. S. B. M. 2529".. 2, 528.92

From Smith store north to State line (part of adjusted circuit).

Smith store, 1.5 miles northwest of, south of road, 50 feet west of sharp bend, on sandstone outcrop; chiseled square marked "U. S. B. M. 2601 "....... 2, 601. 26

Middlesboro quadrangle.

(Latitude $36^{\circ} 30^{\prime}-36^{\circ} 45^{\prime}$; longitude $83^{\circ} 30^{\prime}-83^{\circ} 45^{\prime}$.)

LEE COUNTY.

The elevation given below was determined by a double line of primary leveling brought from a precise-level bench mark near Mascot, Tenn., to Cumberland Gap and thence by a single spur line to Wheeler. The leveling was done by F. L. Foust in 1903. For elevations in Kentucky see Bulletin 554, and for those in Tennessee see Bulletin 441.

From Cumberland Gap east along Louisville \& Nashville $\mathbf{R}$. to Wheeler.

Cumberland Gap, at summit, on Kentucky-Tennessee-Virginia stone Feet. corner post; chisel point..................................... 1,648.47 
Abingdon quadrangle, embracing Damascus, Glade Springs, Marion, and Mount Rogers $15^{\prime}$ quadrangles.

[Latitude $36^{\circ} 30^{\prime}-37^{\circ}$; longitude $81^{\circ} 30^{\prime}-82^{\circ}$.

\section{GRAYSON, RUSSELL, SMYTH, AND WASHINGTON COUNTIES.}

The elevations in the following list were determined in 1908 and 1909 by J. B. Metcalfe, jr., by a single unchecked line from a point 0.3 mile northeast of Housley, Tenn., in Roan Mountain quadrangle, to Damascus, Va. Other lines are closed circuits dependent on this line. For elevations in Abingdon quadrangle in North Carolina and Tennessee see Bulletin 441.

From Damascus south along Laurel Ry. to Laurel Bloomery, thence east along highways to Little Horse Creek, thence north to point 3.1 miles northeast of Konnarock.

Little Horse Creek, 4.7 miles north of, near junction of Big Horse Creek and Mud Fork, near Bill Miller's house, 10 feet east of road, 20 feet northeast of forks, in ledge of rock; aluminum tablet stamped " 2954 "....... 2, 953. 662

Little Horse Creek, 8.5 miles north of, 8 feet east of road, 300 feet northwest of old house; cross on ledge of rock, marked " 3984 ". $3,983.63$

Little Horse Creek, 10.2 miles north of, about 0.25 mile from top of gap between Whitetop and Rogers mountains, 60 feet south of second-class road forks to southwest, 6 feet west of road; cross on ledge of rock, marked

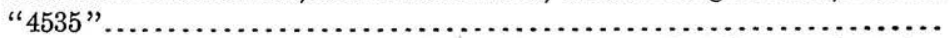

Little Horse Creek, 10.2 miles north of, about 0.25 mile from top of gap between Whitetop and Rogers mountains, about 60 feet south of secondclass road fork to southwest, about 7 feet west of road, in ledge of rock;

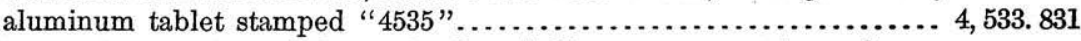

Konnarock, 6.8 miles northeast of, about halfway up mountain road over gap between Whitetop and Rogers mountains, east of road; nail in root of chestnut tree, marked " 4102 "

From Damascus northwest along Virginia-Carolina Ry. to Abingdon.

Damascus, 2.4 miles northwest of, 20 feet west of railroad, 100 feet south of milepost A 13, in ledge of limestone rock; aluminum tablet stamped " 1834 "

Baron station, about 0.5 mile southeast of, 8 feet north of railroad, 35 feet west of milepost A 9, in limestone rock; aluminum tablet stamped "1763". 1, 762.700

Watauga, 1 mile northwest of, 10 feet west of railroad, 260 feet north of bridge 3 over creek, in ledge of rock in cut; aluminum tablet stamped "1924".

Abingdon, south side of new building being put up by Mr. Sumner, facing on Main Street, and 200 feet northeast of Confederate monument, about 3.5 feet from ground and 2 feet from southeast corner of building, in brick wall; aluminum tablet stamped " 2096 ".

$2,095.386$

From Abingdon east along Norfolk \& Western Ry. to Marion.

Abingdon, 3.8 miles east of, 10 feet north of railroad, 12 feet east of milepost " $\mathrm{B} 19 \mathrm{~N} 389$," 50 feet east of cross roads, in rock; aluminum tablet stamped " 2167 ".................................................... end of culvert over small creek, in rock; aluminum tablet stamped " $2110 "$ 
Emory, 2.2 miles east of, 20 feet south of railroad, southeast corner of stone culvert, 40 feet north of road, running parallel to railroad, 1,450 feet east of milepost "B $26 \mathrm{~N} \mathrm{382,"} \mathrm{in} \mathrm{top} \mathrm{of} \mathrm{rock;} \mathrm{aluminum} \mathrm{tablet} \mathrm{stamped}$

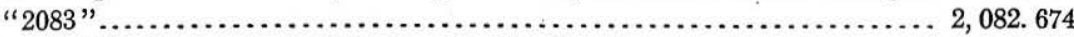

Emory, 6.6 miles east of, 10 feet south of railroad, on southwest corner of culvert, 1,950 feet east of milepost "B $31 \mathrm{~N} \mathrm{377,"} \mathrm{in} \mathrm{rock;} \mathrm{aluminum}$ tablet stamped " 2047 ".

Chilhowie, 0.8 mile east of, 6 feet south of railroad, on southwest abutment of railroad bridge over Middle Fork of Holston River, in top face; aluminum tablet stamped " 1950 "

Chilhowie, 2 miles east of, 10 feet east of bridge over Middle Fork of Holston River, on joint of south rail of railroad; marked "1964" ............ 1, 963.61

Chilhowie, 3.5 miles east of, 7 feet north of railroad, about 1 mile east of Sevenmile Ford, on northeast corner of abutment to trestle over Middle Fork of Holston River and to arch over road, in top face; aluminum tablet stamped " 2013 ".................................... 2, 012.162

Marion, 8 feet north of railroad, about 0.25 mile west of station, on top face of abutment to bridge over Middle Fork of Holston River; cross on top of stone marked " 2126.7 " . . . . . . . . . .

Marion, on west side of station, 1 foot south of northwest corner and 4 feet from ground, in brick wall; aluminum tablet stamped " 2145 "....... 2, 144. 624

From Damascus east along Virginia-Carolina Ry. to point 3.1 miles northeast of Konnarock.

Damascus, 0.2 mile west of station, south side of Main Street, in east face of brick wall, 2.7 feet south of northeast corner of Bank of Damascus, 3.4 feet from ground; aluminum tablet stamped " 1929 ".............. 1, 928. 344

Taylors Valley, 1,360 feet northwest of station, 7 feet east of railroad, in ledge of rock in cut; aluminum tablet stamped " 2366 ".............. 2,365. 210

Konnarock, 3,200 feet southwest of station, 10 feet north of railroad, in ledge of rock; aluminum tablet stamped " 2896 " .................. 2, 895.695

Konnarock, 3.1 miles northeast of, 12 feet north of road forks, on road to Chilhowie; nail in root of 4-foot red-oak tree, marked " 3138.5 " . . . . 3, 137.87

From point 3.1 miles northeast of Konnarock north along highways to Chilhowie.

Konnarock, 3.7 miles northeast of, on road to Chilhowie, east side of road, south side of mountain; cross on ledge of rock, marked " 3187.3 " ...... 3, 186. 61

Konnarock, 5 miles northeast of, on road to Chilhowie, on top of Skulls Gap, east side of road; nail in root of 2.5-foot white-oak tree, marked " 3659.8 ". $3,659.16$

Konnarock, 7 miles north of, on north side of mountain, east side of road; nail in root of 1.5-foot red-oak tree, marked " 2975 " .............. 2, 973.99

Konnarock, 9.4 miles north of, on road to Chilhowie, 35 feet east of road, 50 feet south of large spring with house over it, in limestone rock projecting from foot of hill; aluminum tablet stamped " 2240 "........... 2,239.212

Konnarock, 12.2 miles north of, on road to Chilhowie, 10 feet east of road, 250 feet south of large white house on east side of road and red barn on west side, in ledge of limestone rock; aluminum tablet stamped " 2222 "... 2, 220. 999

Konnarock, 13.7 miles north of, on road to Chilhowie, 30 feet east of road forks, 2 feet above level of road; crosis on ledge of rock, marked " 2097.2 ".. 2, 096. 60

From Marion north along highways to Chatham Hul, thence west to Hayter Gap, thence south to Abingdon.

Marion, 2.5 miles north of, on road to Chatham Hill, in forks of road to west, near Mr. Copenhaver's house; cross on ledge of rock, marked " 2202 " .... 2, 201. 43

Marion, 5.2 miles north of, on road to Chatham Hill, north side of mountain road, about 0.5 mile from bottom of same; cross on rock, marked " 2433 ". 
Marion, 6.2 miles north of, on road to Chatham Hill, east side of mountain Feet. road, just opposite old sawmill; cross on ledge of rock, marked " 2834 ".. 2, 833.53

Marion, 7.8 miles north of, on road to Chatham Hill, 6 feet east of road, 300 feet north of point where road crosses top of mountain, in ledge of rock; aluminum tablet stamped " 3454 ".

Marion, 10.5 miles north of, on road to Chatham Hill, 3 feet west of road and 300 feet west of large barn; cross on ledge of rock, marked " 2392.4 ".. 2, 391.78

Chatham Hill, 1 mile west of, 250 feet south of road forks, 60 feet west of White Oak Branch, 6 feet west of road, in ledge of limestone; aluminum tablet stamped " 2050 ".

Chatham Hill, 2.7 miles west of, on road to Saltville, at top of hill, 6 feet west of road, 10 feet north of gate to field; cross on ledge of rock, marked " 2330.4 ".

Chatham Hill, 6.9 miles west of, 220 feet west of road forks, 200 feet west of point where Cove Creek crosses road, about 100 feet southeast of Cove Creek schoolhouse, 6 feet north of road, 4 feet above level of road, in ledge of limestone; aluminum tablet stamped " 1810 ".

Broad Ford, 1.2 miles west of, on road to Saltville, 6 feet north of road, 3 feet above level of road, in cut along North Fork of Holston River, in slanting ledge of rock; aluminum tablet stamped " 1758 "........... 1, 757.782

Saltville, 3.9 miles east of, on road to Saltville, 175 feet west of road forks, about 0.5 mile east of Southern Gypsum Works, 3 feet east of road; cross on ledge of rock, marked "1741.6"............................ 1.740. 99

Saltville, 0.6 mile east of, 200 feet north of store at Cedar Branch, 8 feet north of road, on northwest abutment to bridge over North Fork of Holston River, in top face; aluminum tablet stamped " 1714 ". . ...... 1, 713.111

Saltville, 2.3 miles west of, on road to Hayter Gap, 7 feet south of road forks and 45 feet northeast of house; cross on large rock, marked " 1926 "...... 1, 925.34

Saltville, 5.1 miles west of, on road to Hayter Gap, 100 feet west of bridge over Tumbling Creek, in road forks north; cross on rock, marked "1765". 1, 764. 09

Saltville, 5.8 miles west of, on road. to Hayter Gap, 30 feet north of road

forks south; cross on sandstone, marked " 1733 " ..................... 1, 732.54
Saltville, 5.8 miles west of, on road to Hayter Gap, 575 feet west of road forks south, -about 0.8 mile southwest of Hazel Springs, 75 feet east of where creek crosses road, 6 feet north of road, in sandstone ledge; alumi-

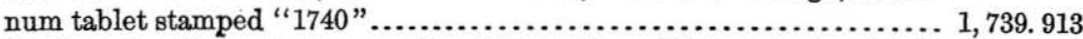

Saltville, 9.3 miles east of, on road to Hayter Gap, 100 feet north of forks north where road goes over Hayter Gap, 16 feet west of road, in sandstone ledge; aluminum tablet stamped " 1656 " ....................... 1, 655.950

Hayter Gap, 1 mile south of, on road to Abingdon, 10 feet northwest of road forks east, at east end of bridge over Wolf Creek, 150 feet northeast of junction of North Fork of Holston River and Wolf Creek; cross on rock, marked " 1532.4 " ....................................... 1, 531.78

Hayter Gap, 1 mile south of, on road to Abingdon, 100 feet northeast of bridge over Wolf Creek, 75 feet northeast of road forks east, 10 feet east of road, in ledge of rock; aluminum tablet stamped " 1536 " .......... 1, 535. 202

Hayter Gap, 4.7 miles south of, on road to Abingdon, 6 feet north of road forks south, near house; cross on ledge of rock, marked " 1498 "......... 1, 497. 32

Hayter Gap, 6 miles south of, on road to Abingdon, 7 feet east of road, 50 feet south of store, on north bank of Tool Creek; cross on ledge of rock,

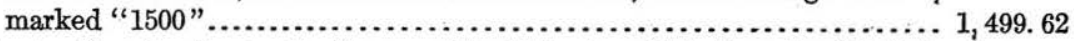

Hayter Gap, 6 miles south of, on road to Abingdon, 75 feet south of Baily's store on Tool Creek, 15 feet east of where road crosses Tool Creek, in ledge of rock; aluminum tablet stamped " 1503 " 
Hayter Gap, 9.8 miles south of, 1 mile southwest of White's mill, on road to Abingdon, 20 feet northwest of second-class road west, 300 feet south of creek crossing, in ledge of rock; aluminum tablet stamped " 2008 ".

From Hayter Gap northeast along highways to Belfast Mills (spur line).

Hayter Gap, 2.4 miles north of, on top of Clinch Mountain, 10 feet west of road, in sandstone ledge; aluminum tablet stamped " 3012 "

Hayter Gap, 4.6 miles north of, northeast of road forks east, 75 feet west of point where Soop Creek crosses road, about 0.25 mile south of Rockdell; cross on rock, marked " 2188.3 "............................. 2, 187.67

Hayter Gap, 6.1 miles north of, about 300 feet south of road west to Elk Garden, 6 feet east of road, in limestone ledge; aluminum tablet stamped " 2131 "

Old Rosedale, about 400 yards east of, 150 feet west of road north to Honaker, 8 feet north of road, in limestone ledge; aluminum tablet stamped " 2281 "

Rosedale, about 2.5 miles east of, 30 feet southwest of road forks north, south side of road; cross on rock, marked " 2330.6 " ................. 2, 330. 03

Rosedale, 2.8 miles east of, about 0.25 mile west of John Vessel's residence, 100 feet south of road forks, 10 feet east of road, in sandstone; aluminum tablet stamped " 2314 "...................................... 2, 313.810

Belfast Mills, 20 feet west of forks, 35 feet east of blacksmith shop; cross

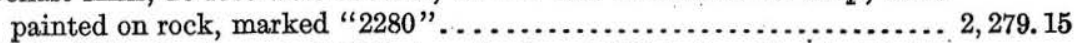

Belfast Mills, 1 mile east of, 75 feet south of road, 300 feet northeast of $\mathrm{C}$. W. Grant's residence, 6 feet north of branch of Indian Creek, in limestone ledge; aluminum tablet stamped " 2293 "...................... 2, 292.530

Big Stone Gap, Bramwell, Bucu, Burkes Garden, Clintwood, Coeburn, Glade Springs, Hagan, Hansonville, Middlesboro, Nolansburg, Pound, Pounding Mill, Regina, Richlands, Sneedville, and Wise quadrangles.

\section{DICKENSON, LeE, RUSSELL, TAZEWELL, AND WISE COUNTIES.}

The following elevations were determined by primary leveling, using prism level and yard rod. The line was double run from Graham to Cumberland Gap. The circuit from Norton via Pound, Clintwood, and Dante, to a point near St. Paul was single. The elevations, which were based on the 1903 adjustment, are unchanged by the 1907 or 1912 adjustments and accord with those in bulletins 434 and 441.

The leveling was done by L. F. Biggs in 1912. Additional leveling with $Y$ level and New York rod was done in 1912 in Clintwood quadrangle by C. W. Arnold, in Wise quadrangle by J. B. Metcalfe, in Pound quadrangle by Arnold, Metcalfe, and H. S. Senseney, and in 1913 by Senseney and S. R. Archer; in Bucu, Clintwood, Coeburn, and Regina quadrangles in 1913 by Senseney.

The work was done in cooperation with the State.

\section{BIG STONE GAP QUADRANGLE.}

[Latitude $36^{\circ} 45^{\prime}-37^{\circ}$; longitude $82^{\circ} 45^{\prime}-83^{\circ}$.]

From milepost $\mathbf{7}$ along Lousville \& Nashville R. R. to point 3 miles east of Pennington.

Milepost N 7; spike in base of, marked "1773"................. Feet.

Milepost N 8; spike in base of, marked " 1717 "................... 1, 717.27 
Appalachia, 1.2 miles east of, 400 feet west of milepost $\mathrm{N} 9$; in large rock $15^{\circ}$ Feet. feet south of track; aluminum tablet stamped "1669 B 351912 ". . . . 1, 669. 206

Milepost N 10, 900 feet east of; spike in west support of switch stand, marked " 1655 ;" aluminum tag placed near spike.................. 1, 654.97

Milepost N 11, opposite; spike in base of section post, marked " 1635 "... 1, 635. 46

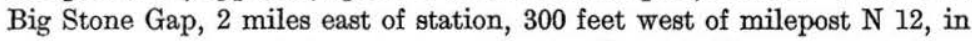
north end of east abutment of overhead railroad bridge at point where railroad crosses river; aluminum tablet stamped " 1580 " ............. 1, 580.297

Milepost N 13; spike in base, marked " 1526 "................... 1, 525. 80

Big Stone Gap, in front of station; top of rail..................... 588.5

Big Stone Gap, 1 mile west of station, 400 feet east of milepost N 15, in cut, 15 feet south of track, in large rock; aluminum tablet stamped "1463 B

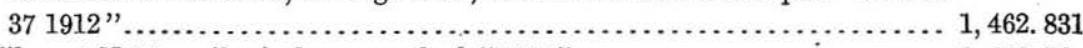

Milepost N 16; spike in base, marked " 1459 "....................... 1, 458.56

Milepost N 17; spike in base, marked " 1469 ".................. 1, 469. 14

Big Stone Gap, 4 miles west of station, 75 feet east of milepost N 18, 20 feet north of track, in rock; aluminum tablet stamped "1460 B 38 1912".... 1, 459.966

Milepost N 19; spike in base, marked "1488".................. 1, 487.97

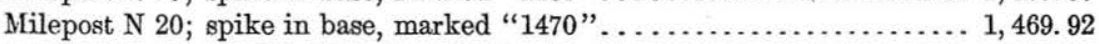

Ohlinger, in front of station; top of rail....................... 502.0

Ohlinger, 2 miles west of station, 375 feet west of milepost N 21, 10 feet north of track, in rock cut; aluminum tablet stamped "1434 B 39 1912". 1, 434.055

Milepost N 22; spike in base, marked " 1417 ". . . . . . . . . . . . . . 1, 416.73

Milepost N 23; spike in base, marked "1416". .................. 1, 415.94

Dryden, 1 mile east of, 350 feet west of milepost $\mathrm{N} 24$, in rock 10 feet south of track; aluminum tablet stamped "1435 B 401912 ".............. 1, 434. 118

Milepost N 25, opposite Dryden station; spike in base of milepost, marked "1440".

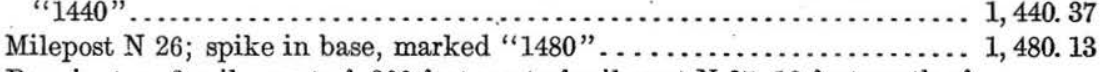

Pennington, 3 miles east of, 300 feet west of milepost N 27, 10 feet north of track, in rock cut; aluminum tablet stamped "1483 B 41 1912"...... 1, 483.282

BRAMWELL QUADRANGLE.1

[Latitude $37^{\circ} 15^{\prime}-37^{\circ} 30^{\prime}$; longitude $81^{\circ} 15^{\prime}-81^{\circ} 30^{\prime}$.]

From Graham along Norfolk \& Western Ry. to Furnace.

Graham, on west side of front entrance to Bank of Graham; aluminum tablet stamped " 2389 " ................................... 2, 389. 450

Furnace signboard, in second telegraph pole west of; spike, aluminum tag

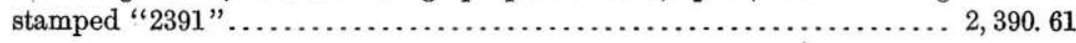

BUCU QUADRANGLE.

[Latitude $37^{\circ}-37^{\circ} 15^{\prime}$; longitude $82^{\circ}-82^{\circ} 15^{\prime}$.]

From milepost N 45 along Norfolk \& Western Ry. to milepost N 43.

Milepost N 44; spike in base, marked " 1768 ".................. 1, 767. 82

Honaker, 2.5 miles west of, in limestone 20 feet north of track and on east side of creek; aluminum tablet stamped "1719 B 18 1912"......... 1, 718.625 Milepost N 43; spike in base, marked " 1685 " ................... 1,684.64

${ }^{1}$ For elevations in West Virginia in this quadrangle see Bulletin 477. 
From Colley south 2 miles, thence west along highway to Street schoolhouse, thence north to Hanger, thence west to a point 1.1 miles west of Vicey.

Colley post office, opposite, at foot of drain, in mulberry tree; copper nail Feet. with washer, painted "U. S. B. M. 1299 "....................... 1, 298. 50

Colley post office, about 1.5 miles south of, east side of road, in ledge; aluminum tablet stamped " $1304 \mathrm{Va}$ "............................... 1, 304.241

Colley post office, about 2 miles south of, 15 feet south of Priest Fork, west side of road, in large stump; copper nail with washer, painted "U. S. B.M. $1311 "$.

Priest Fork, about 1.2 miles east of mouth of, on south side of road to Abners Gap, in root of tree; copper nail with washer, painted "U. S. B. M. 1452".. 1, 452. 11

Abners Gap, summit of, center of road; elevation painted "U. S. 1582" ... 1, 582.1

Honaker Lumber Co.'s $\log$ road, at switch; top of rail. . ............. 1, 496. 6

Bee post office, about 0.1 mile east of, 75 feet west of switch, north side of track, in ledge; aluminum tablet stamped "1482 Va".............. 1, 481. 737

Bee post office, about 1.1 miles east of, north side of track, on Russell Fork, in root of tree; copper nail with washer, painted "U. S. B. M. 1424".... 1, 424. 00

Deel post office, about 300 feet east of, 50 feet west of switch, in root of chestnut tree; copper nail with washer, painted "U. S. B. M. 1432"... 1, 431.63

Hurricane schoolhouse, about 300 feet south of, opposite Jackson's store, 15 feet west of footbridge over Hurricane Creek, in ledge; aluminum tablet stamped " $1457 \mathrm{Va}$ "...................................... q, 456.446

Forks of Hurricane, 20 feet east of road crossing, south side of road, in root of apple tree; copper nail with washer, painted "U. S. B. M. 1492 " .... 1, 492. 18

Forks of Hurricane, about 1.2 miles east of, 300 feet south of Sam Presley's house, west side of road, in root of tree; copper nail with washer, painted "U. S. B. M. 1548 "...................................... 1, 547. 47

Presley schoolhouse, about 600 feet west of, 15 feet south of road, in ledge; aluminum tablet stamped "1609 Va"........................... 1, 608.571

Presley schoolhouse, about 1.2 miles east of, south side of road, in root of tree; copper nail with washer, painted "U. S. B. M. 1652"............ 1, 651.49

Presley schoolhouse, about 2.4 miles east of, about 500 feet east of Keene's store, south side of road, in root of tree; copper nail with washer, painted "U. S. B. M. 1705"....................................... 1, 704.78

Presley schoolhouse, about 3 miles east of, about 150 feet west of sharp bend in road, at foot of Fletcher's Ridge, north side of road, in ledge; aluminum tablet stamped " $1723 \mathrm{Va}$ "................................. 1, 722.682

Fletcher's store, center of road opposite; elevation painted "U.S.B.M. $2290 "$ ".

Indian Grave Gap, about 1 mile south of, at fork in road, in root of tree; copper nail with washer, painted "U. S. B. M. 2450 " .............. 2, 449. 68

Indian Grave Gap, 25 feet north of fork in road, west side of road, on ledge; chiseled square painted "U. S. B. M. 2069 " ...................... 2,068. 80

Street schoolhouse, 20 feet northeast of doorway, in rock; aluminum tablet stamped " $1667 \mathrm{Va}$ ".

Street schoolhouse, about 1.1 miles north of, 100 feet north of ford, west side of road, in root of tree; copper nail with washer, painted "U. S. B. M.

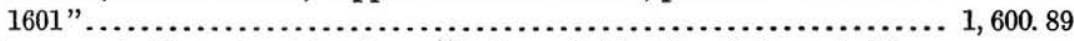

Skeggs post office, about 1 mile south of, west side of road, in root of tree; copper nail with washer, painted "U. S. B. M. 1559 "............. 1, 558. 29

Skeggs post office, center of road in front of; elevation painted "U.S. 1513". 1,512. 7

Skeggs post office, about 1 mile north of, 175 feet south of Harvey Childress's house, 25 feet south of footbridge over Garden Fork, in ledge; aluminum

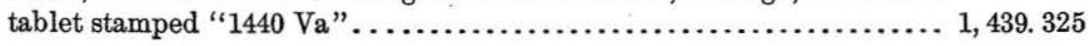


Skeggs post office, about 2.5 miles north of, east side of road, in root of tree; Feet. copper nail with washer, painted "U.S. B. M. 1368" ............... 1, 368.13

Skeggs post office, about 3.5 miles north of, east side of road, in root of tree; copper nail with washer, painted "U. S. B. M. 1342" ........... 1, 342.03

Hanger post office, about 500 feet south of, on south bank of Levisa River, opposite private-road crossing, in ledge; aluminum tablet stamped "1300 Va".

Hanger post office, about 1.3 miles west of, north side of road, on ledge; chiseled square painted "U. S. B. M. 1259 " ..................... 1, 258. 63

Hanger post office, about 2.7 miles west of, north side of road, on ledge; chiseled square painted "U. S. B. M. 1252" ..................... 1, 252. 08

Hanger post office, about 3.4 miles west of, 400 feet west of Jim Nicholl's house, south side of road, in ledge; aluminum tablet stamped."1187 Va". 1, 187.110

Van Sant post office, about 2.9 miles east of, north side of road, on ledge; chiseled square painted "U. S. B. M. 1157" .................... 1, 156. 85

Van Sant post office, about 1.8 miles east of, north side of road, on ledge; chiseled square painted "U. S. B. M. 1138" ...................... 1, 137.28

Ratliff Chapel, in front of, in center of road; elevation painted "U.S. 1188". 1, 188

Van Sant post office, about 350 feet south of, west side of Prater Creek, in ledge; aluminum tablet stamped "1114 Va".................... 1, 113.876

Van Sant post office, about 0.8 mile south of, 20 feet north of fork in road, east side of road, in root of tree; copper nail with washer, painted "U. S. B. M. 1158 "..................................... 1, 157.24

Van Sant post office, about 1.8 miles south of, 25 feet north of fork in road, east side of road, on ledge; chiseled square painted "U. S. B. M. 1237". 1, 236.57

Van Sant post office, about 2.7 miles south of, about 400 feet east of Stiltner's house, south side of road, in ledge; aluminum tablet stamped "1449 Va"............................................ 1, 448. 724

War Fork Gap, summit of, 15 feet north of road, in root of tree; nail painted "U. S. B. M. 1883 " ....................................... 1, 882.57

War Fork Gap, about 1.4 miles west of, south side of road, in root of beech tree; copper nail with washer, painted "U. S. B. M. 1665" ............ 1, 664.82

War Fork Gap, about 2.1 miles west of, south side of road, at edge of creek, in ledge; aluminum tablet stamped " $1575 \mathrm{Va} " \ldots \ldots \ldots \ldots \ldots \ldots \ldots \ldots . . .574 .712$

Prater post office, about 0.25 mile west of, 8 feet south of road, on bank of Russell Prater Creek, on ledge; chiseled square painted "U.S. B.M.

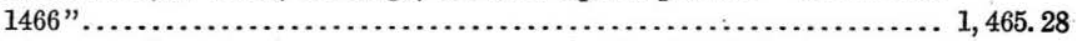

Prater post office, about 1.4 miles west of, north side of road, in stump; copper nail with washer, painted "U.S. B. M. 1482" ................. 1, 481.24

Vicey post office, 200 feet east of, 20 feet north of road, in ledge; aluminum tablet stamped " $1433 \mathrm{Va}$ ".................................. 1,432.156

Vicey post office, about 1.1 miles west of, 12 feet south of road, in root of beech tree; copper nail with washer, painted "U. S. B. M. 1443"....... 1, 442. 34

From point 2 miles south of Colley south along highway to Bucu (spur leveled twice).

Colley post office, about 3.4 miles south of, east side of road, in root of beech tree; copper nail with washer, painted "U. S. B. M. 1359" ...... 1, 359.32

Tiny post office, about 0.25 mile north of, 75 feet north of fork in road, east side of road, in ledge; aluminum tablet stamped "1438 Va"......... 1, 437.976

Tiny, opposite old post-office building, in center of road ............. 1,423.8

Tiny post office, about 1.2 miles south of, west side of road, in stump; copper nail with washer, painted "U. S. B. M. 1454" ................ 1, 454. 14

Bucu post office, about 0.7 mile north of, east side of road, on ledge; chiseled square painted "U. S. B. M. 1581 " ........................... 1,580.56

Bucu post office, about 0.25 mile north of, east side of road, in ledge; aluminum tablet stamped " $1631 \mathrm{Va}$ "............................ 1,630.568 
BURKES GARDEN QUADRANGLE.

[Latitude $37^{\circ}-37^{\circ} 15^{\prime}$; longitude $81^{\circ} 15^{\prime}-81^{\circ} 30^{\prime}$.]

From milepost N 98 along Norfolk \&. Western Ry. to milepost N 82 .

Feet.

Milepost N 98; spike in base, aluminum tag marked " 2405 "............ 2, 405. 12

Milepost N 97; spike in base, aluminum tag marked " 2433 "............ 2, 432.50

St. Clair, in front of station; top of rail.......................... 2,446. 3

St. Clair, 0.5 mile west of station, 200 feet east of milepost 96,20 feet north of track; aluminum tablet stamped "1 2468 " ............... 2,467.777

Milepost N 96; spike in base of, aluminum tag stamped " 2508 "........... 2, 508.26

Milepost N 94; spike in base, aluminum tag stamped " 2556 ".......... 2, 555. 95

Bailey, 270 feet east of station, 480 feet west of milepost $N$ 93, 15 feet north of track, in rock; aluminum tablet stamped " 26142 ":......... 2,613.94

Bailey, in front of station; top of rail............................ 2, 609.1

Milepost N 92; spike in base, aluminum tag stamped " 2650 "........... 2, 649.98

Milepost N 91; spike in base, aluminum tag stamped " 2699 "........... 2, 698.80

Tip Top, in front of station; top of rail.......................... 2,748.2

Tip Top, 850 feet west of, 20 feet south of track, in bowlder; aluminum tablet stamped "2757 31912 "................................ 2, 756. 789

Milepost N 89; spike in base, aluminum tag stamped " 2727 ".......... 2, 727. 39

Milepost N 88; spike in base, aluminum tag stamped " 2672 "........... 2, 671. 77

Wittens Mill, 1.5 miles east of station, 0.2 mile west of milepost $\mathrm{N} \mathrm{87,10}$ feet south of railroad, in ledge; aluminum tablet stamped "2611 41912 ".. 2, 610.500

Milepost N 86; spike in base, aluminum tag stamped " 2571 "........... 2, 571.25

Wittens Mill, in front of station; top of rail........................ 2, 536.8

Milepost N 85; spike in base, aluminum tag stamped " 2515 ".......... 2, 515.44

Five Oaks, in front of station; top of rail marked " 2467 "................ 2,472.5

Tazewell, 3 miles east of, 700 feet west of Five Oaks station, 20 feet north of track at milepost N 84, in rock; aluminum tablet stamped "2467 5 1912 B" ................................................. 2,467.151

Milepost N 83; spike in base, aluminum tag stamped " 2411 "............ 2, 411. 37

Milepost N 82; spike in base, aluminum tag stamped " 2391 ".......... 2, 391.03

CLINTWOOD QUADRANGLE.

[Latitude $37^{\circ}-37^{\circ} 15^{\prime}$; longitude $82^{\circ} 15^{\prime}-82^{\circ} 30^{\prime}$.]

From point 3 miles west of Clintwood east to point 1 mile north of Dante.

Clintwood, 2 miles west of, at junction of Coburn and Pound roads, on culvert on west edge of road; chisel point marked "1613 U. S.".......... 1,613.11

Clintwood, on concrete stoop 15 feet west of door to courthouse; aluminum tablet stamped "1784 B 81912 ".................................. 1, 784.032

Clintwood, 0.7 mile southeast of, west edge of road at summit of hill; $2 \frac{1}{2}$-foot oak tree, scribed "1972 U. S." .............................. 1, 971.76

Clintwood, 1.1 miles southeast of, at junction of roads; 4 -foot chestnut tree, scribed "1829 U. S."..................................... 1, 828.88

Clintwood, 2 miles southeast of, south edge of road; spike in base of $2 \frac{1}{2}$-foot white-oak tree, scribed "1547 U. S." ........................... 1, 546.92

Clintwood, 2.6 miles southeast of, 50 feet west of Cranesnest River at ford, in slate ledge; aluminum tablet stamped "1440 B 9 1912"......... 1, 439.862

Cranesnest Ford, 1.3 miles southeast of, south edge of road; spike in base of $1 \frac{1}{2}$-foot hickory tree, scribed " 1622 U. S."..................... 1, 621.24

Summit of ridge between Cranesnest and McClure rivers, north edge of road, 100 feet west of top, in bowlder; aluminum tablet stamped "1925 B 10 $1912 "$ 
Clintwood, 5.8 miles southeast of, 60 feet west of ford, 60 feet west of forks of road, south bank of McClure River; copper nail in root of $2 \frac{1}{2}$-foot sycamore tree, scribed and painted "1437 U. S.".................. 1, 436.42

Stratton, 2.8 miles north of, west edge of road, at base of oak tree; chisel point on bowlder, scribed on tree "1465 U. S."................... 1, 464.69

Stratton, 1.8 miles north of, east edge of road, at north end of flat, in bowlder; aluminum tablet stamped "1486 B 111912 ".................... 1,485.965

Stratton, 400 feet north of post office, north edge of road; chisel point on bowlder, marked "1500 U. S." ............................. 1,499.45

Nora, 100 feet south of schoolhouse, 20 feet east of road, in bowlder; aluminum tablet stamped "1505 B 121912 "....................... 1, 505.068

Nora, 1.2 miles southeast of, west edge of road; copper nail in base of 3-foot chestnut tree, scribed "1520 U. S."........................... 1, 519.80

Nora, 2.2 miles southeast of, west edge of road; chisel point on highest part of large bowlder, marked "1551 U. S." ....................... 1, 551. 00

Nora, 3.8 miles southeast of, 800 feet south of mouth of Honey Creek, east edge of road, in bowlder; aluminum tablet stamped "1616 B 131912 "... 1, 615.936

Nora, 4.5 miles south of, 300 feet south of creek forks, west edge of road; copper nail in base of 2 -foot oak tree, scribed " 1654 U. S."........... 1, 653.83

Nora, 5.4 miles south of, east edge of road, at point where road leaves creek; copper nail in sycamore tree, scribed " 1727 U. S."............... 1, 726. 84

Nora, 5.9 miles south of, east edge of road, near east end of tunnel; copper nail in large white-oak stump, scribed "1877 U. S."............... 1, 876.47

Dante, 1.5 miles north of, 100 feet south of summit of Trammel Gap, east edge of road; chisel point on bowlder, marked " $2550 \mathrm{U}$. S."........... 2, 550. 06

Trammel Gap, 500 feet south of, south edge of road at switchback, in large bowlder; aluminum tablet stamped " 2507 B 141912 "............... 2, 506.588

Dante, 1 mile north of, south edge of road; copper nail in base of 1-foot hickory tree, scribed "2193 U. S." ......................... 2, 192. 43

\section{From Clintwood northeast along highway to Haysi.}

Clintwood; in concrete stoop of courthouse, 15 feet west of door; aluminum tablet stamped "1784 B 81912 ".......................... 1, 784.032

Clintwood, 1.5 miles northeast of, 700 feet south of stream crossing, west side of road; chiseled square on rock ledge, marked "B. M. 1718"...... 1, 717. 43

Clintwood, 2.3 miles northeast of, south of road; chiseled square on rock bowlder, marked " B. M. 1809 ".............................. 1,809. 06

Clintwuod, 3.2 miles northeast of, 200 feet south of stream crossing, 40 feet south of road, in rock ledge; bronze tablet stamped "1801 Va. 1912"... 1,800.615

Clintwood, 3.9 miles northeast of, 50 feet northeast of road forks; nail in root of hickory tree, marked "B. M. 1870" ...................... 1,869.65

Clintwood, 4.9 miles northeast of, 25 feet northeast of road forks; nail in root of red-oak tree, marked "B. M. 1994" .................... 1, 994. 12

Clintwood, 5.6 miles northeast of, 500 feet east of house, south of road, in outcrop of rock; aluminum tablet stamped "1789 Va. 1912" ........... 1, 788.740

Clintwood, 6.6 miles northeast of, 30 feet west of house, 100 feet north of road forks; chiseled square on outcrop rock, marked "B. M. 1856 " .... 1, 855. 18

Tandy, 1 mile northeast of, 100 feet west of Cranes Nest River, at road crossing, in bowlder; aluminum tablet stamped "1304 Va. 1912"...... 1, 303.947

Tandy, 1.7 miles northeast of, north of road; chiseled square on rock ledge, marked "B. M. 1577".................................. 1,576.45

Tandy, 3.1 miles northeast of, 0.1 mile east of Watson Davis's house, south of road; nail in root of poplar tree, marked "B. M. 1820 "............. 1, 819.31

Tandy, 3.7 miles northeast of, 140 feet north of house north of road; chiseled square on outcrop ledge, marked "B. M. 1551 " ................. 1,550.73 
Tandy, 4.2 miles northeast of, 100 feet northeast of Mount Olive Church, in triangle at road forks, in large bowlder; aluminum tablet stamped " 1822 Va. $1912 "$

Tandy, 5.3 miles northeast of, 20 feet west of road forks; nail in root of large white-oak tree, marked "B. M. 1821 " .......................... 1, 820.24

Haysi, 50 feet east of; chiseled square on outcrop, marked "B. M. 1522".. 1, 521.46

Haysi, 0.4 mile east of, north of road, in rock ledge; aluminum tablet stamped "1381 Va. 1912"................................... 1, 380.432

Haysi, 0.7 mile east of, 500 feet north of road crossing of McClures River, 0.5 mile west of Mart; cut in base of hemlock tree, marked "B. M. 1288.58" (Carolina, Clinchfield \& Ohio Ry. b. m.)....................... 1, 289.400

At point 2 miles north of Haysi and at Lonesome Branch (set from Carolina, Clinchfleld \& Ohio Ry. bench marks).

Carolina, Clinchfield \& Ohio Ry. b. m., station 135, R. 581, residency No. 2, White Oak ..................................... 1, 234. 07

Haysi, about 2.25 miles north of, 400 feet north of north end of railroad bridge, on bank of river, in ledge; bronze tablet not stamped......... 1, 220.658 Carolina, Clinchfield \& Ohio Ry. b. m., 70 feet R. 460+50 White Oak, residency No. 2, No. 16 b. m. in list of Elkhorn extension............ 1, 178. 67

Lonesome Branch, cement culvert over, east side of; bronze tablet not

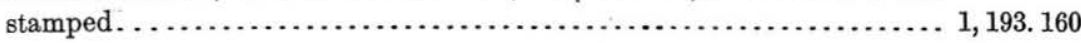

\section{From Haysl southeast along highway to Colley.}

Haysi, 0.4 mile east of, north side of road, in rock ledge; aluminum tablet stamped "1381 Va. 1912 " $1,380.432$

Haysi, about 1 mile east of, about 500 feet east of junction of Russell and Prater creeks, 6 feet east of Prater, on bank, in stump; copper nail with washer, painted "U. S. B. M. 1262".

Sand Lick (Birchleaf post office), about 1 mile northwest of, north side of road down Russells Fork, in root of tree; copper nail with washer, painted "U. S. B. M. 1270 "................................ 1,269. 61

Sand Lick, at bend in road, opposite Jackson's store, east side of road, in sandstone ledge; aluminum tablet stamped "1287 Va".............. 1, 287. 126

Sand Lick, about 1.6 miles east of, 60 feet below wire footbridge at junction of Russell and Frying Pan creeks, in root of large chestnut tree; copper nail with washer, painted "U. S. B. M. 1280 "................... 1, 280. 09

Colley post office, opposite, at foot of drain, in mulberry tree; copper nail with washer, painted "U. S. B. M. 1299 " ...................... 1, 298. 50

Colley post office, about 1.5 miles south of, east side of road, in ledge; aluminum tablet stamped "1304 Va."......................... 1, 304.241

Colley post office, about 2 miles south of, 15 feet south of Priest Fork, west side of road, in large stump; copper nail with washer, painted "U.S. B.M. 1311 "............................................... 1, 310.99

From point near Vicey southwest along highway to Haysi.

Vicey post office, about 2.3 miles west of, south side of road, in root of tree; copper nail with washer, painted "U. S. B. M. 1387 " .............. 1, 386.70

Mart post office, about 1.6 miles east of, 100 feet west of Doe Branch, north side of road, in ledge; aluminum tablet stamped " $1377 \mathrm{Va}$ "............ 1, 376. 434

Mart post office, about 0.5 mile east of, 60 feet south of fork in road, in stump; copper nail with washer, painted "U. S. B. M. 1353" .......... 1, 352. 00 Mart post office, in front of, center of road; elevation painted "U. S. 1285".. 1, 285. 
From point 1.7 miles north of Fullers Gap north along highway to point 2 miles west of Clintwood.

Fullers Gap, about 1.7 miles north of, east side of road, on bowlder; chis- Feet. eled square.............................................. $1,925.63$

Tracys Fork, center of bridge over, painted erroneously " $1626 \mathrm{~W}-8$ " ...... 1, 735.7

Fullers Gap, about 2.8 miles north of, about 600 feet north of iron bridge over Tracys Fork, east side of road, in culvert; bronze tablet stamped "1616 Va" (stamped erroneously) ............................... 1, 726. 311

Culvert at road east, painted erroneously " 1584 "..................... 1, 694.2

Steeles Fork, bridge over, 11 feet above water, floor of, painted erroneously

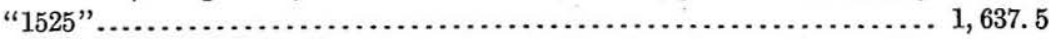

Carter's store, about 1.3 miles north of, west side of road, on culvert; chiseled square, painted erroneously " 1454 "......................... $1,563.46$

Lyons Fork, at road up, painted erroneously " 1432 " ............... 1, 541.9

Intersection of Coeburn-Clintwood and Wise-Clintwood roads, painted er-

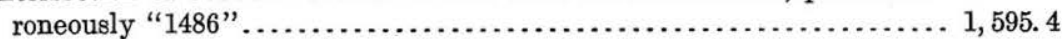

Power's store, about 0.2 mile south of, east side of road, in culvert; bronze tablet stamped "1519 Va".................................. 1, 519.015

Cranes Nest River, near Mullin's house; surface of water................. 1, 495.6

Power's store, about 1.1 miles north of, west side of road, on ledge; chiseled square painted "U. S. B. M. 1512"......................... 1, 511.29

Cranes Nest River, at junction of Lick Fork; surface of water............ 1, 482.8

Foraker post office, about 1.2 miles north of, west side of road, in stump; copper nail with washer, painted "U. S. B. M. 1609" ................ 1, 608.43

Hibbitts Gap, summit of, center of road...................... 796.8

Darwin post office, 150 feet west of Long Fork, at path leading to Mr. Grizzle's house, in rock, south side of road; bronze tablet stamped "1555 Va". 1, 554.787 Darwin, at road crossing; surface of water in Long Fork................ 1,548.4

Darwin, about 1.2 miles north of, east side of road, in stump; copper nail with washer, painted "U. S. B. M. 1637" ........................ 1, 636.58 Clintwood, 2.2 miles south of, 200 feet south of wooden bridge over Laurel Branch, east side of road, on rock; chiseled square painted " 1622 " ...... 1, 621.88

\section{COEBURN QUADRANGLE.}

[Latitude $36^{\circ} 45^{\prime}-37^{\circ}$; longitude $82^{\circ} 15^{\prime}-82^{\circ} 30^{\prime}$.]

\section{From Castlewood station along Norfolk \& Western Ry. to milepost N 8 .}

Castlewood, in east end, south abutment of highway bridge over Clinch River; aluminum tablet stamped "1484 B 24 1912"................. 1, 483.405 Milepost N 25; spike in base, marked " 1485 " . . . . . . . . . . . . . . . . 1, 485. 24 Milepost N 24; spike in base, marked " 1481 "..................... 1, 481.18 Fink, on southwest corner of south abutment of Norfolk \& Western Ry. bridge over Lick Creek; chiseled cross (railroad elevation, 1,474.08 feet). 1, 481. 34

St. Paul, in sidewalk at west side of west basement window (south front) of St. Paul National Bank; aluminum tablet stamped "1488 25 B 1912".. 1, 487.783 St. Paul, 0.8 mile west of, in north end of west abutment of Norfolk \& Western Ry. bridge 1390; aluminum tablet stamped "1521 B 26 1912".. 1, 520.708 Milepost N 21; spike in base, marked " 1563 "..................... 1,562.50 Milepost N 20; spike in base, marked " 1605 " ................... 1, 604. 75 Milepost N 19; spike in base, marked " 1637 ".................... 1, 637. 20 Virginia City, 400 feet west of station, in rock in rear of tool house; aluminum tablet stamped "1688 B 27.1912 "........................... 1, 687.981 Milepost N 17; spike in base, marked " 1806 " ................... 1, 805. 58 Milepost N 16, about 200 feet east of, on north end of east abutment of bridge 1369; chiseled cross marked " 1796 " 
Pine, 0.9 mile east of station, 330 feet west of milepost N 15, in north end of west abutment of railroad bridge; aluminum tablet stamped "1881 B 28 $1912 "$

(19lepost N 14; spike in base, marked "1962"....................... 1, 961. 46

Pine, in front of station; top of rail.............................. 969.6

Milepost N 13; spike in base, marked " 2038 "...................... 2, 038. 22

Milepost N 12; spike in base, marked " 2013 ". ..................... 2, 012.42

Coeburn, 0.6 mile east of, 900 feet east of milepost $\mathrm{N} 11$, in northwest corner of stone culvert under railroad; aluminum tablet stamped "1994 B 29

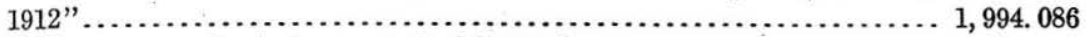

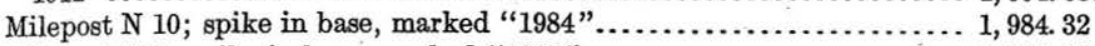

Milepost N 9; spike in base, marked " 1995 " ...................... 1, 994. 89

Milepost N 8; spike in base, marked " $2000 " . \ldots \ldots \ldots \ldots \ldots \ldots \ldots \ldots \ldots . \ldots . . \ldots 2,000.31$

From point near Dante south along Carolina, Clinchfleld \& Ohio Ry. to Fink.

Dante, 50 feet northeast of post office, in south end of west abutment of railroad bridge; aluminum tablet stamped "1765 B 151912 "............ 1, 764. 148

Dante; southwest corner of bridge abutment (railroad elevation, 1,765.12

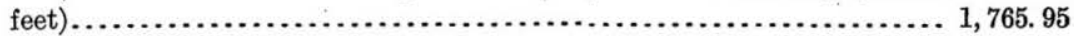

Dante, 0.8 mile south of, west edge of railroad; chisel point on bowlder... 1, 724. 25

Dante, 1.4 miles south of; on southeast foundation of water tank; cross on plate, steel plate stamped "1700 U. S." ....................... 1, 699. 44

Milepost 44, 60 feet south of, in base of telephone pole; spike, aluminum tag stamped "1652 U. S.". ................................. 1, 652.02

Dante, 3.5 miles south of, 30 feet east of railroad, at road crossing, 700 feet south of Hamlin station, in granite cliff; aluminum tablet stamped "1623 B $151912 "$

Milepost 46, 140 feet north of, in northeast corner of trestle; copper nail, aluminum tag stamped "1580 U. S."......................... 1,579. 84

Milepost 47, 360 feet north of, west side of track, in base of telephone pole; spike, aluminum tag stamped "1512 U. S.".................... 1, 511. 88

Fink, 1 mile east of St. Paul, on southwest corner of south abutment of Norfolk \& Western Ry. bridge over Lick Creek; chiseled cross marked " 1481 " (railroad elevation, 1,474.08 feet).

From Coeburn north along highway to point 1.7 miles north of Fullers Gap.

Coeburn, about 1 mile south of Norfolk \& Western Ry. abutment, east side of north end; aluminum tablet stamped "1994 Va"............... 1, 994. 086

Coeburn, Norfolk \& Western Ry. station, main line; top of east rail....... 1,989. 0

Bondtown, the Bondtown Mercantile Co. building, at northeast corner, in cement walk; chiseled square painted erroneously " 1887 "......... 1, 996.63

Toms Creek, trestle over, 430 feet east of junction with branch to Toms Creek and Cranes Nest River, south side of track, in guardrail; copper nail with washer, painted erroneously " 1890 ".................... 2,000.19

Fullers Gap, about 0.25 mile south of, on west side of new graded road, in culvert; bronze tablet stamped "2081 Va.".................... 2, 190. 880 NoтE.-Error of 110 feet in stamping.

Fullers Gap, summit of, center of road, painted erroneously " 2202 "...... 2,312.0

Fullers Gap, 0.5 mile north of, south side of culvert over Tracys Fork; chiseled square painted erroneously " 2055 ". $2,165.39$ $44136^{\circ}-$ Bull. 562-14-4 
GLADE SPRINGS QUADRANGLE.

[Latitude $36^{\circ} 45^{\prime}-37^{\circ}$; longitude $81^{\circ} 45^{\prime}-82^{\circ}$.]

From milepost 1 along highway to Old Rosedale.

Milepost 1; spike in base ................................... 1,832.89

Milepost 2; spike in base.................................... 1, 803.72

Milepost 3; spike in base................................... 1,818. 76

Milepost 4; spike in base.................................... 1, 817. 20

Blackford, in central pier of highway bridge over Clinch River, in north end; aluminum tablet stamped "1811 B 1912"................... 1,811. 350

Blackford, 1 mile south of, on east side of road opposite house; spike in post. 1, 938. 94

Blackford, 2 miles south of, north of road; chisel point on culvert......... 2, 095. 37

Blackford, 2.5 miles south of, west edge of road; spike in root of tree..... 2, 286. 76

Old Rosedale, 400 yards east of, 150 feet west of road north to Honaker, 8

feet north of road, in limestone ledge; aluminum tablet stamped " 2281 ". 2, 280.669

HAGAN QUADRANGLE.

[Latitude $36^{\circ} 30^{\prime}-36^{\circ} 45^{\prime}$; longitude $83^{\circ} 15^{\prime}-83^{\circ} 30^{\prime}$.]

\section{From point 1 mile west of Hubbard Springs along Norfolk \& Western Ry. to milepost} N 59.

Hubbard Springs, 1 mile west of, 700 feet west of milepost $\mathrm{N} 43$, in rock on south right of way line; aluminum tablet stamped " 1625 B 461912 "... 1, 624. 719

Milepost N 44; spike in base marked " 1647 "....................... 1, 646. 98

Milepost N 45; spike in base marked " 1612 "...................... 1, 582.22

Hogans, 75 feet northwest of northeast corner of station, in large rock on north side of road; aluminum tablet stamped "1525 B 471912 "....... 1, 524. 705

Milepost N 47; spike in base marked " 1573 "........................ 1, 543.16

Milepost N 48; spike in base stamped " 1634 "..................... 1, 603.60

Rose Hill, 2 miles east of, 700 feet west of milepost $\mathrm{N} 49$, in south end of east abutment of railroad bridge; aluminum tablet stamped "1604 B 48 $1912 "$

Milepost N 50; spike in base not stamped........................ 1, 520.59

Milepost N 51, about 1,000 feet east of Rose Hill station; spike in base... 1, 455.94

Rose Hill, 1.5 miles west of, 2,400 feet east of milepost N 53; aluminum tablet stamped "1471 B 491912 "............................... 1,470.475

Milepost N 54; spike in base stamped " 1414 "...................... 1,414. 50

Enwing, 0.5 mile east of, 200 feet west of milepost $\mathrm{N} 55$, in north end of east abutment of railroad bridge; aluminum tablet stamped " 1397 B 50

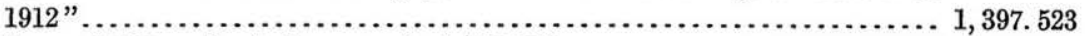

Milepost N 56; spike in base marked " $1386 " \ldots \ldots \ldots \ldots \ldots \ldots \ldots \ldots \ldots . .1,385.92$

Milepost N 57; spike in base marked " 1382 ".................... 1, 381.95

Caylor, 1.3 miles east of, 1,200 feet west of milepost 58, in rock, 10 feet north of tracks, 100 feet east of crossing; aluminum tablet stamped " 1390

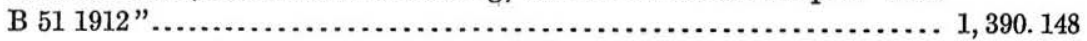

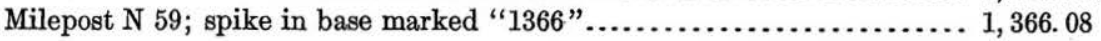

\section{HANSONVILLE QUADRANGLE.}

[Latitude $36^{\circ} 45^{\prime}-37^{\circ}$; longitude $82^{\circ}-82^{\circ} 15^{\prime}$.]

From milepost N 43 along Norfolk \& Western Ry. to milepost N 27.

Milepost N 42; spike in base, marked " 1612 " ..................... 1, 611.42

Finney, 0.5 mile west of, 200 feet west of milepost $N$ 41, in large rock 20 feet

south of track; aluminum tablet stamped "1583 B 191912 "........... 1, 583.029

Milepost N 40; spike in base, marked " 1567 ".................... 1, 567.28 
Milepost N 39; spike in base, marked " 1552 "

Milepost N 38 ; spike in base, marked " 1559 ".

Cleveland, 2.6 miles east of, 125 feet east of milepost $\mathrm{N} 37$, in rock 10 feet south of track; aluminum tablet stamped "1555 B 201912 " .......... 1, 555.057

Milepost N 36; spike in base, marked " 1548 " .................... 1, 547.60

Milepost N 35; spike in base, marked " $1530 " \ldots \ldots \ldots \ldots \ldots \ldots \ldots \ldots \ldots \ldots 1,530.22$

Cleveland, in south end of east abutment of highway bridge over Clinch

River; aluminum tablet stamped "1523 B 211912 " . . . . . . . . . . . . 1, 522.654

Milepost N 34; spike in base, marked " 1525 " ................... 1, 524.95

Milepost N 33; spike in base, marked " 1524 " ..................... 1, 521.41

Kiser, at Francisco's store; sycamore stump (railroad elevation, 1,506.18

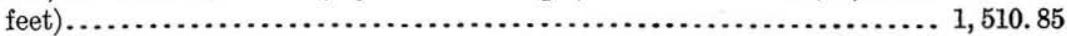

Kiser, 825 feet west of, on west end of south abutment of railroad bridge; aluminum tablet stamped "1514 B 221912 " ..................... 1, 513.614

Milepost N 31; spike in base, marked " 1524 " ..................... 1, 524. 19

Milepost N 30; spike in base, marked " 1505 " ..................... . 1, 505.29

Milepost N 29; spike in base, marked " 1497 " .................... 1,496.87

Canterton, 2 miles west of, 1,225 feet west of milepost N 28, in stone 10 feet

north of track; aluminum tablet stamped "1493 B 231912 " .......... 1, 492.719

Milepost N 27; spike in base, marked " 1504 " .................... 1, 503.99

\section{MIDDLESBORO QUADRANGLE (VIrginia part).1}

\section{[Latitude $36^{\circ} 30^{\prime}-36^{\circ} 45^{\prime}$; longitude $83^{\circ} 30^{\prime}-83^{\circ} 45^{\prime}$.]}

From milepost N 60 along Louisville \& Nashville R. R. to milepost N 66.

Milepost N 60; spike in base, marked " $1339 " \ldots \ldots \ldots \ldots \ldots \ldots \ldots \ldots \ldots . . \ldots 1,338.46$

Wheeler, 2 miles east of station, 300 feet west of milepost $\mathrm{N} 61$, in rock 25

feet south of track; aluminum tablet stamped "1336 B 52 1912"...... 1, 335.591

Milepost N 62; spike in base, marked " 1303 "....................... 1, 302.98

Wheeler, in front of station; top of rail. ......................... 1, 301.6

Wheeler, 0.3 mile southwest of station, 75 feet south of switch stand, in southeast corner of culvert; aluminum tablet stamped "1257 B 531912 " 1, 256.571

Milepost N 64; spike in base, marked " 1267 "....................... 1, 267.29

Milepost N 64, just east of overhead wagon bridge; spike in base, marked " 1253 ".................................................. 1, 252.50

Milepost N 66; spike in base, marked " 1237 "...................... 1, 236.34

Shawanee, 1.8 miles east of station, in top of Virginia-Tennessee State-line post on north right of way line of Louisville \& Nashville R. R.; aluminum tablet stamped "1249 B 67 1912"............................. 1, 249. 321

\section{NOLANSBURG QUADRANGLE.}

[Latitude $36^{\circ} 45^{\prime}-37^{\circ}$; longitude $83^{\circ}-83^{\circ} 15^{\prime}$.]

From milepost N 28 along Louisville \& Nashvile R. R. to Pennington station.

Milepost N 28; spike in base, marked " 1423 "...................... 1, 422.56

Milepost N 29; spike in base, marked " 1362 "..................... 1, 362.34

Pennington, 640 feet west of station, in rock 10 feet south of track; aluminum

tablet stamped "1386 B 421912 ".............................. 1, 385. 767

1 For elevations in Kentucky in this quadrangle see Bulletin 554 and for those in Tennessee see Bulletin 441. 


\title{
POUND QUADRANGLE.1
}

\author{
[Latitude $37^{\circ}-37^{\circ} 15^{\prime}$; longitude $82^{\circ} 30^{\prime}-82^{\circ} 45^{\prime}$.]
}

From point 1 mile south of Glamorgan along Wise Terminal R. R. to Glamorgan, thence along highways to point 3 miles west of Clintwood.

Feet.

Norton, 1.7 miles north of, 15 feet east of track; bowlder marked “ 2090 ”. . 2, 089.91

Norton, 3.7 miles north of, 400 feet north of small switch, 15 feet west of track, on east bank of creek; 4-foot oak tree scribed and painted " 2115 ".. 2, 114.35

Glamorgan, 1 mile south of, at south end of village, 300 feet south of switch, 25 feet west of track, 20 feet east of end of stone fence, in bowlder; aluminum tablet stamped " 2183 B 11912 ".

Glamorgan, 100 feet south of, west edge of road; chisel point on concrete culvert, marked " 2219 "

Glamorgan, 0.8 mile north of, west edge of road; chisel point on concrete culvert, marked " 2197 " ................................... 2, 196. 38

Glamorgan, 1.5 miles north of, east edge of road, at switchback; chisel point on bowlder, marked " 2320 U. S."

Glamorgan, 2 miles north of, summit of Indian Mountain, 40 feet east of road, in bowlder; aluminum tablet stamped "2483 B 21912 " ......... 2,483.268

Indian Mountain, 1.1 miles north of, west edge of road; chisel point on rock, marked "2154 U. S."

Indian Mountain, 2 miles north of, west edge of road, 50 feet north of J. Grit Freeman's mail box; chisel point on culvert, marked " 1826 " ....... 1, 825.55

Indian Mountain, 2.6 miles north of, at foot of long grade, west edge of road, west edge of north abutment of bridge over fork creek; chisel point, marked " 1679 ".

Riner's farmhouse, 1 mile north of, west edge of road, in slate cliff 2 feet above road; aluminum tablet stamped "1638 B 3 1912" . . . . . . . . . . 1, 637.633

Pound, 4.3 miles south of, east side of road; copper nail in 3-foot maple tree, marked "1640 U. S."

Pound, 3 miles south of, west bank of creek, west edge of road, where road crosses to east side of creek; copper nail in $2 \frac{1}{2}$-foot oak tree, marked " 1608 U. S."

Pound, 2.7 miles south of, east edge of road, in top of culvert; aluminum tablet stamped "1606 B 4 1912"

Pound, 1.2 miles south of, 50 feet north of railroad crossing, 30 feet south of schoolhouse, 15 feet west of road; copper nail in base of walnut tree, marked "1596 U. S."

Pound, 1,000 feet north of station, east edge of road, in concrete culvert; aluminum tablet stamped " 1547 B 5 1912"

Pound, 1.2 miles southeast of, 400 feet north of road forks, 200 feet north of store, west edge of road; copper nail in base of $2 \frac{1}{2}$-foot chestnut tree, scribed "1598 U. S." ....................................... 597.40

Pound, 2.3 miles east of, 800 feet north of road forks, west edge of road, in base of 18-inch sycamore tree; copper bolt marked "1573 U. S." ...... 1, 572. 89

Pound, 3.4 miles east of, 400 feet east of Mead farm house, south edge of road, in large bowlder under maple tree; aluminum tablet stamped "1646 B 61912 "

Pound, 4 miles east of, north edge of road, near foot of steep grade; chisel point of large bowlder, marked "1771 U. S." .................... 1, 770.99

Pound, 5 miles east of, in gap at summit of ridge, east edge of road; copper nail in base of 1-foot black-oak tree, scribed " 2156 U. S." 
Summit of ridge, 0.7 mile east of, south edge of road; copper nail in base Feet. of 3-foot white-oak tree, scribed "1677 U. S.".................... 1, 677.06

Clintwood, 4 miles west of, 150 feet west of schoolhouse, 20 feet north of road, in bowlder; aluminum tablet stamped "1617 B 7 1912"......... 1, 616.285

Clintwood, 3 miles west of, south edge of road; copper nail in base of $2 \frac{1}{2}$-foot white-oak tree, marked "1574 U. S.".......................... 1, 573. 44

From Pound Gap south along highway to Pound.

Pound Gap, summit of, 25 feet east of road, 50 feet south of house; chiseled square on ledge, marked "U. S. B. M. 2408 "..................... 2, 407. 43

Pound Gap, 1 mile south of, 60 feet west of Rocky Branch station, opposite shed, 8 feet east of stump, in ledge; aluminum tablet not stamped.... 1, 940. 812

Pound, 2.3 miles north of, 5 feet west of narrow-gage railroad; nail in root of beech tree, marked "U. S. B. M. 1598 "....................... 1, 597.52

From Pound southwest along highway to Dewey (double spur).

Pound, 1,000 feet north of station, east edge of road, in concrete culvert; aluminum tablet stamped "1547 B 5 1912" ..................... 1, 546. 452

Pound, 1 mile west of, 250 feet west of road crossing, south of track; chiseled square on ledge, marked "B. M. 1557 " .......................... 1, 557.118

Pound, 3.1 miles west of, 150 feet east of white house, south of road; chiseled square on bowlder, marked "B. M. 1580 "....................... 1, 579. 79

Pound, 4 miles west of, 200 feet southeast of Glady Fork schoolhouse, south of road, in rock ledge; aluminum tablet stamped "1599 Va. 1912"..... 1, 598. 669

Pound, 5.7 miles west of, 50 feet southeast of road forks, north of road; chiseled square on rock ledge, marked "B. M. 1632" ............... 1, 632.07

Dewey, 600 feet north of, 8 feet west of road, 4 feet above road, in solid rock; aluminum tablet stamped "1693 Va".......................... 1, 692.418

\section{At Lipps (double spur line from point near Norton).}

Lipps, 0.5 mile south of, 20 feet west of road, opposite store, in sandstone rock; aluminum tablet stamped " $2231 \mathrm{Va}$ "

From Kentucky-Virginia State line along highways to Dewey.

Flat Gap, 570 feet east of post office, north end of stone culvert under highway, on top of; chiseled square marked " 1919.3 ".................. 1, 918. 97

Flat Gap, 0.3 mile east of highway culvert over North Fork of Pound River, on top of north end of west concrete guardrail; chiseled square marked " 1884.5 "

Flat Gap, 1 mile east of, at road crossing on top of ridge between North and South forks of Pound River, at head of Meadow Branch, at top at north end of gap, 200 feet west of bend in road to south, north side of road, east side of gap, at fence corner, in root of 2-foot chestnut tree; copper nail marked " 2116.5 "....................................... 2, 116.15

Dewey, 1.8 miles west of, at fork in road west up South Fork of Pound River, 200 feet east of greenhouse standing on north side of road, at mouth of hollow from north, on top of north end of stone culvert under road; chiseled square marked " 1837.3 "

Dewey, 1.4 miles west of, steel highway bridge over South Fork of Pound River, on west abutment, top of south wing wall; chiseled square marked " 1764.6 " ............................................ 1, 764.27

Near Carter's store (on line from Coeburn to Clintwood).

Carter's store, about 0.3 mile north of, near Flat Gap, east side of road, top of culvert; chiseled square painted erroneously " 1499 "............ 1, 608.51 
POUNDING MILL QUADRANGLE.

[Latitude $37^{\circ}-37^{\circ} 15^{\prime}$; longitude $81^{\circ} 30^{\prime}-81^{\circ} 45^{\prime}$.]

From milepost N 82 along Norfolk \& Western Ry. to milepost N 67 .

Milepost N 81 ; spike in base, aluminum tag stamped “ 2382 ”.

Tazewell, 700 feet east of station, railroad bridge over creek; chisel point on south end of east abutment, marked " 2380 ".

Tazewell, 60 feet south of station, on south edge of road, in bowlder; aluminum tablet stamped " 2386 B 6 Va. 1912" ................... 2, 385. 81]

Milepost N 80; spike in base, aluminum tag stamped " 2376 " ......... 2, 376. 05

Milepost N 79; spike in base, aluminum tag stamped " 2370 " ........... 2, 370. 30

Milepost N 78; spike in base, aluminum tag stamped " 2365 "............ 2, 365. 36

Pisgah, 150 feet west of tool house, 30 feet north of track, in bowlder; aluminum tablet stamped " 2360 B 7 Va. 1912"......................... 2, 359. 596

Milepost N 76, 40 feet west of, higher than track; spike in base of ledge, marked " 2419 "............................................ 2, 418.72

Youngs station; spike in base of semaphore, aluminum tag stamped " 2422 ". 2, 422

Maxwell, 65 feet south of mail crane, 25 feet northeast of store, in bowlder; aluminum tablet stamped " 23718 B 1912"......................... 2, 370.922

Milepost N 74; spike in base, aluminum tag stamped " 2328 "........... 2, 327.51

Milepost N 73; spike in base, aluminum tag stamped " 2304 "............ 2, 303. 44

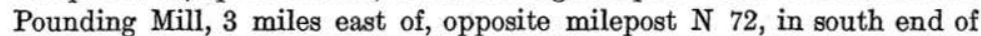

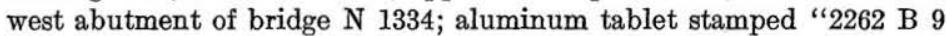
$1912 "$

Gillespie, in front of station; top of rail.......................... 259. 8

Milepost N 71; spikein base, aluminum tag stamped " 2229 " ........... 2, 227.41

Milepost N 70; spike in base, aluminum tag stamped " 2193 "........... 2, 191. 34

Pounding Mill, in front of station; top of rail........................ 2,157.6

Pounding Mill, 550 feet west of station, 10 feet south of track, in limestone

at west end of rock cut; aluminum tablet stamped "2153 B 101912 ".... 2, 150.958

Milepost N 68; spike in base, marked " 2117 "...................... 2, 114. 87

Milepost N 67; spike in base, marked " 2078 "..................... 2, 076.04

\section{REGINA QUADRANGLE. 1}

\section{[Latitude $37^{\circ} 15^{\prime}-37^{\circ} 30^{\prime}$; longitude $82^{\circ} 15^{\prime}-82^{\circ} 30^{\prime}$.]}

Near The Towers (set from Carolina, Clinchfield \& Ohio Ry. bench marks).

Carolina, Clinchfield \& Ohio Ry. b. m., Maple, 50 feet to right of station, $330+80$, residency No. 1 (last b. m., of list of Elkhorn extension)...... 1, 143.42

The Towers, about 0.5 mile west of, 60 feet south of footbridge over Russells Fork, north side of track, in culvert; bronze tablet not stamped..... 1, 128. 210

\section{RICHLANDS QUADRANGLE.}

[Latitude $37^{\circ}-37^{\circ} 15^{\prime}$; longitude $81^{\circ} 45^{\prime}-82^{\circ}$.]

From milepost N 66 along Norfolk \& Western Ry. to milepost N 45 .

Milepost N 66; spike in base, marked " 2032 " ...................... 2,030.06

Cedar Bluff, in front of station; top of rail........................ 2,001.2

Cedar Bluff, 720 feet west of station, 220 feet east of milepost $N$ 65, railroad

bridge over Clinch River, in north end of west abutment; aluminum tab-

let stamped "1996 B 111912 "............................... 1, 993. 648

Milepost N 64; spike in base, marked " 1959 "..................... 1, 957.04

Milepost N 63; spike in base, marked " 1938 "..................... 1, 935. 72

Richlands, in front of station; top of rail........................ 936.3 
Richlands, 2,000 feet west of, in top of south end of west abutment of highway bridge over Clinch River; aluminum tablet stamped "1937 B 12 Feet. $1912 "$ $1,935.196$

Milepost N 61; spike in base, marked " 1927 "......................... 1, 924.81

Milepost N 60; spike in base, marked " $1920 " \ldots \ldots \ldots \ldots \ldots \ldots \ldots \ldots \ldots . \ldots . . \ldots 1,919.42$

Raven, 280 feet east of station, in north end of west abutment of bridge 1358; aluminum tablet stamped "1909 B 131912 "....................... 1, 909. 247

Raven, in front of station; top of rail........................... 910.9

Milepost N 58; spike in base, marked " 1903 "..................... 1, 902.70

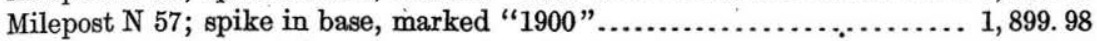

Dan; spike in base of signboard, marked " 1895 ".................... 1,894. 59

Milepost $N$ 55, 100 feet east of, in limestone 10 feet north of track; aluminum

tablet stamped "1896 B 141912 "............................... 1, 895.831

Milepost N 54, 200 feet east of; spike in base of "C." post, marked " 1885 ".. 1, 884. 71

Milepost N 53; spike in base, marked " 1877 "....................... 1, 876. 52

Milepost N 52; spike in base, marked " 1868 "...................... 1,867. 53

Swords Creek, 0.6 mile east of, in front of Charles King's residence, in limestone 35 feet north of track; aluminum tablet stamped " 1864 B 15 1912".. 1, 864.000

Milepost N 51; spike in base, marked " 1867 "...................... 1,866.92

Swords Creek, in front of station; top of rail....................... 1,867.8

Milepost N 50; spike in base, marked " 1869 "...................... 1,869. 20

Gardner, 80 feet east. of station, in limestone 25 feet south of track; aluminum tablet stamped "B 161912 "............................ 1, 913.040

Milepost N 48; spike in base, marked "1911" . . ................. 1, 911.05

Honaker, 0.6 mile east of, bridge 1461; bolt in north end of west guardrail.. 1,882. 30

Honaker, in north face at northwest corner of public-school building; aluminum tablet stamped "1924 B 1912 "......................... 1, 924. 122

Honaker, 360 feet east of station, in limestone 70 feet north of track and north of stone culvert under railroad; aluminum tablet stamped "B 17

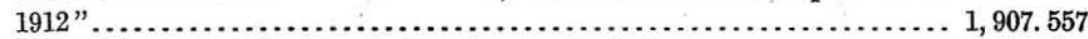

Milepost N 46, opposite Honaker station; spike in base............. 1,908. 93

Milepost N 45; spike in base, marked " 1853 " . . . . . . . . . . . . . . . . $1,852.80$

From point 0.6 mile east of Honaker to milepost 1.

Honaker, 0.6 mile east of, bridge 1461; bolt in north end of west guardrail.. 1,882. 30 Milepost 1 ; spike in base................................... 1,832.89

SNEEDVILIE QUADRANGLE.

[Latitude $36^{\circ} 30^{\prime}-36^{\circ} 45^{\prime}$; longitude $83^{\circ}-83^{\circ} 15^{\prime}$.]

From milepost N 31 along Louisville \& Nashville R. R. to milepost N 42.

Milepost N 31; spike in base, marked " 1379 "....................... 1, 379. 33

Milepost N 32; spike in base, marked " 1428 "....................... 1,427.96

Milepost N 33; spike in base, marked "1492".................... 1, 491.60

Ben Hur, 600 feet east of, 15 feet south of track, in rock ledge; aluminum

tablet stamped " 1533 B 431912 ". ........................... 1, 532.712

Milepost N 34, 1.5 miles west of Ben Hur; spike in base, marked "1615".. 1, 614. 95 Note.-The post is painted "N 34 " but should be "N 35 ."

Milepost N 36; spike in base, marked " $1680 " \ldots \ldots \ldots \ldots \ldots \ldots \ldots \ldots \ldots . .1,680.03$

Ocoonita, 500 feet east of station, in north end of culvert under railroad;

aluminum tablet stamped "1674 B 441912 " ..................... 1, 673.512

Milepost N 38; spike in base, marked " 1630 "....................... 1, 629.89

Milepost N 39; spike in base, marked " 1600 " ..................... 600.02

Hubbard Springs, 2 miles east of, 125 feet west of milepost N 40, in rock on north right of way line; aluminum tablet stamped "1556 B 451912 ". 1, 555.549

Milepost N 41; spike in base, marked " 1599 " ................... 1, 599. 18

Milepost N 42; spike in base, marked " 1568 " . . . . . . . . . . . . . 


\section{WISE QUADRANGLE.}

[Latitude $36^{\circ} 45^{\prime}-37^{\circ}$; longitudede $82^{\circ} 30^{\prime}-82^{\circ} 45^{\prime}$.]

From point 1 mile east of Norton along Norfolk \& Western Ry. to Norton, thence along Louisville \& Nashville R. R. to milepost N 6.

Tacoma, 1 mile east of, at northwest corner of yard to company store, in Feet. rock just outside of fence; aluminum tablet stamped "2000 B 301912 ". 2, 000. 628

Milepost N 7; spike in base, marked " 1997 " . . . . . . . . . . . . . . . 1, 997. 27

Tacoma, in front of station; top of rail . . . . . . . .

Milepost N 6; spike.in base, marked "1998" ..................... 1, 998. 63

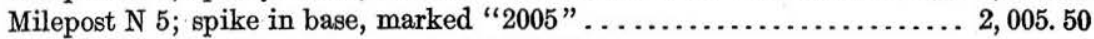

Milepost N 4; spike in base, marked " 2014 " . . . . . . . . . . . . . 014.94

Norton, 3.3 miles east of, in north end of second pier from east end of bridge

1405; aluminum tablet stamped " 2043 "......................... 2,043.629

Milepost N 2; spike in base, marked " 2081 " ................... 2, 081.26

Milepost N 1; spike in base, marked " $2101 " \ldots \ldots \ldots \ldots \ldots \ldots \ldots \ldots .2,101.10$

Norton, in front of station; top of rail.......................... 102.7

Norton, in stone step at front entrance to First National Bank building; aluminum tablet stamped " 2135 B 321912 " .................... 2, 135.121

Norton, 3,000 feet east of station, 75 feet west to Wise Terminal Junction; 18-inch hemlock tree (railroad elevation, 2101.96 feet) .............. 2, 101.13

Milepost N 2, L 288 C 116; spike in base, marked " 2078 "............. 2, 077.82

Blackford, 1 mile east of, at milepost N 3, in rock 15 feet south of track; aluminum tablet stamped "2017 B 331912 " ...................... 2,017.216

Milepost N 4; spike in base, marked " $1952 " \ldots \ldots \ldots \ldots \ldots \ldots \ldots \ldots \ldots \ldots$ 1, 951.62

Milepost N 5; spike in base, marked " $1890 " \ldots \ldots \ldots \ldots \ldots \ldots \ldots \ldots \ldots .1,889.82$

Blackford, 2 miles west of, 170 feet west of milepost $N$, in rock 30 feet south of track at east end of cut; aluminum tablet stamped "1827 B 34 $1912 "$

From Norton along Wise Terminal R. R. to point 1 mile south of Glamorgan.

Norton, 1.7 miles north of, 15 feet east of track; chiseled mark on bowlder,

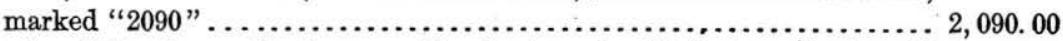

Norton, 3.7 miles north of, on east bank of creek, 400 feet north of small switch, 15 feet west of track; 4-foot oak tree, scribed and painted " 2115 ". 2, 114.40

From point 3.7 miles north of Norton north to Lipps (double spur line).

Norton, 4.5 miles north of, 4 feet west of road; chiseled square on to $\rho$ of concrete culvert, marked " 2126 " ............................. 2, 125.97

Lipps, 1.5 miles south of, 75 feet north of road west, 6 feet west of road; chiseled square top of concrete culvert, marked " 2157 "............ 2, 156.68

Peterstown quadrangle.

GILES COUNTY.

The elevations in the following list were determined by primary levels and accord with the 1912 adjustment. For elevations in West Virginia in this quadrangle see Bulletin 477. The leveling was done in 1913, by H. S. Senseney. 


\section{PETERSTOWN QUADRANGLE. 1}

[Latitude $37^{\circ} 15^{\prime}-37^{\circ} 30^{\prime}$; longitude $80^{\circ} 45^{\prime}-81^{\circ}$.]

From Peterstown, W. Va., southwest to Glenlyn, Va. (Virginia part of line from Mercers Salt Works, W. Va.).

Peterstown, 1.2 miles south of, south side of road, 10 feet east of gate, on Feet.

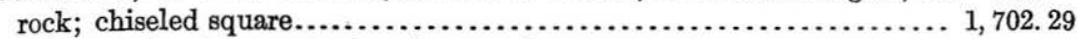

Rich Creek, 250 feet south of station, trestle over road, in west end of south abutment; bronze tablet stamped " 1531 " ...................... 1, 530.497

Rich Creek, New River at ford; surface of water, Sept. 19, $1913 \ldots \ldots \ldots$. . 1, 499

Lurich, in front of station; top of rail...................... 1, 535.5

Glenlyn, in front of station; top of rail..................... 533

Glenlyn, 528 feet west of station, south side of track, in culvert; aluminum tablet stamped " 1535 " .................................... 1,535. 109

1 For the elevations in West Virginia in this quadrangle see Bulletin 477. 


\title{
APPENDIX A
}

\section{ELEVATIONS ADJUSTED BY THE COAST AND GEODETIC SURVEY FROM PRECISE LEVELING.}

Bowling Green, Charles City, Doswell, Hampton, Mount Vernon, Newport News, Richmond, Stafford, Toano, Williamsburg, and Yorktown quadrangles.

CAROLINE, ELIZABETH CITY, FAIRFAX, HANOVER, HENRICO, JAMES CITY, NEW Kent, PRINCE WILLIAM, PITTSYlVANIA, STAFFORD, WARWICK, AND YoRK COUNTIES.

The following descriptions and elevations are taken from reports of the Coast and Geodetic Survey and are republished by permission of the superintendent of that bureau. The bench marks were established by the Coast and Geodetic Survey and were included in the 1907 adjustment by that survey, and were not changed by the 1912 adjustment.

\author{
BOWLING GREEN QUADRANGLE. \\ [Latitude $38^{\circ}-38^{\circ} 15^{\prime}$; longitude $77^{\circ} 15^{\prime}-77^{\circ} 30^{\prime}$. \\ From Penola to point near Summit.
}

Milford, in front of brick section house of Richmond, Fredericksburg \& Potomac R. R., 100 yards north of railroad station, in ninth course above ground and in fifth brick north of front or east door; copper bolt (C. \&

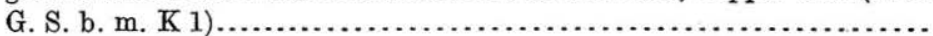

Feet. 102. 323

Guinea, 1 mile south of, in stone retaining wall to brick culvert, 100 meters north of milepost 48 , on west side of track and north side of culvert, on third step from top, near center of exposed part of stone; bottom of roughly cut square hole (C. \& G. S. b. m. I 2)

Summit, 0.5 mile south of, 200 meters south of milepost 53 , on east side of track, in north stone of sandstone coping at end of brick culvert; bottom of square cut lettered "U. S. $\square$ B. M." (C. \& G. S. b. m. I 1)...........

CHARLES CITY QUADRANGLE.

[Latitude $37^{\circ} 15^{\prime}-37^{\circ} 30^{\prime}$; longitude $77^{\circ}-77^{\circ} 15^{\prime}$.]

From point near Lanexa to Roxbury.

Providence Forge, in north side of chimney at north end of Mr.Townsend's dwelling house, in eighth course of bricks from ground and in eighth brick north end of chimney; copper bolt (C. \& G. S. b. m. Q)..........

Roxbury, in brick chimney at west end of T. L. Walker's residence, in tenth course of bricks from ground and in third brick from west side of chimney; copper bolt (C. \& G. S. b. m. P 5).......................

DOSWELL QUADRANGLE.

[Latitude $37^{\circ} 45^{\prime}-38^{\circ}$; longitude $77^{\circ} 15-77^{\circ} 30^{\prime}$.]

From point near Doswell to Penola.

Doswell, 0.2 mile south of, at bridge 37 of Richmond, Fredericksburg \& Potomac R. R., 1.2 miles below Chesapeake \& Ohio Ry. junction, in southwest corner of south abutment of wooden bridge, 0.17 meter from extreme north edge of rock and 0.46 meter from extreme west edge; bottom of square cut (C. \& G. S. b. m. M)

146.565 
Rutherglen, in west wall of brick railroad section house, in twelfth course from ground and in third brick from northwest corner, in right side of wall as one enters door; cross in end of copper bolt (C. \& G. S. b. m. K 3).......

Feet. 205.127

Penola, in west face of brick chimney at back of house and store owned by Mrs. A. B. De Jarnett and facing railroad track, in seventeenth course above brick foundation to house and in second brick from northwest corner; copper bolt (C. \& G. S. b. m. K 2)

\section{HAMPTON QUADRANGLE.}

[Latitude $37^{\circ}-37^{\circ} 15^{\prime}$; longitude $76^{\circ} 15^{\prime}-76^{\circ} 30^{\prime}$.]

From Old Point Comfort lighthouse to Newport News.

Old Point Comfort, on southwest side of lighthouse at Fort Monroe, in stone about 1.5 feet from ground, referenced by middle of lower horizontal edge of indenture; a figure U. S. C.S. (C. \& G.S. b. m. Old Tidal)..

Old Point Comfort, on southwest side of lighthouse at Fort Monroe, in stone directly beneath the Old Tidal b. $\mathrm{m}$. and 0.215 meter above ground, 0.0125 meter in diameter and 0.055 meter in length; copper bolt (C. \& G.

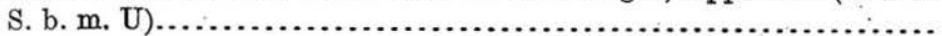

Fort Monroe, on outer wall of fort, on right-hand side of postern gate, in second granite block from gate, in eleventh course of stone; cross cut (C.

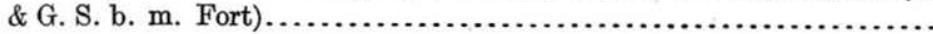

\section{At Morrison.}

Morrison, in brick chimney of one-story frame house in yard of D. H. Jones's. residence, on north side of chimney, in tenth course from ground and in second brick from outer or northeast corner; copper bolt (C. \& G. S. b. m.

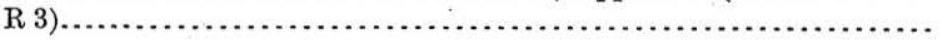

\section{MOUNT VERNON QUADRANGLE.}

[Latitude $38^{\circ} 30-39^{\circ}$; longitude $77^{\circ}-77^{\circ} 30^{\prime}$.]

From point near Widewater to point near Alexandria.

Quantico, in side wall of brick building owned by Max Lansburgh, opposite railiroad station, east of track, in twelfth course above ground and in third brick from northwest corner; copper bolt (C. \& G. S. b. m. G 5)........

Woodbridge, 0.5 mile north of, in top at northwest corner of large granite block set in red sandstone of first pier from north end of bridge over Occoquan River, under the end of iron superstructure, east of track;

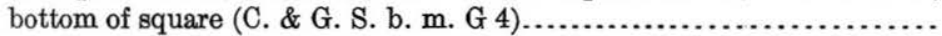

Pohick Creek, north abutment of iron bridge of Richmond, Fredericksburg \& Potomac R. R., east of track, southeast corner of abutment, in edge of capstone; surface of offset cut (C. \& G. S. b. m. G 3)...................

Accotink, 0.2 mile north of, in north abutment to small wooden railroad bridge (No. 20), west of track, on offset below top on which end of bridge rests; bottom of square cut (C. \& G. S. b. m. G 2)...................

Cameron Run, 3 miles west of Alexandria, in top of third step from top of north granite abutment to iron bridge of Baltimore \& Potomac R. R., over Cameron Run, east of track; bottom of square hole, lettered "U. S.

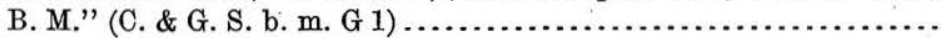

Alexandria, near middle of sill of northwest window of customhouse, 0.12 meter from extreme west edge of sill and 0.115 meter from extreme east

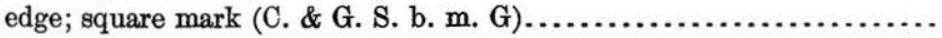

35.222

68. 746 


\section{NEWPORT NEWS QUADRANGLE.}

[Latitude $36^{\circ} 45^{\prime}-37^{\circ}$; longitude $76^{\circ} 15^{\prime}-76^{\circ} 30^{\prime}$.]

At Newport News.

Newport News, south side of Lafayette House, near middle of house, on stone doorsill, 0.055 meter from south edge of sill and 0.1663 meter from extreme west edge; bottom of square cut (C. \& G. S. b. m. S)...........

Feet.

22. 357

\section{RICHMOND QUADRANGLE.}

[Latitude $37^{\circ} 30^{\prime}-37^{\circ} 45^{\prime}$; longitude $77^{\circ} 15^{\prime}-77^{\circ} 30^{\prime}$.]

From Richmond to Ashland.

Richmond, near north end of Richmond, Fredericksburg \& Potomac R. R. freight station, on granite sill of second door on west side, 0.150 meter from extreme west edge of door and 0.654 meter from north side; bottom of

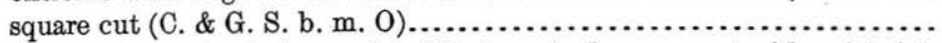

Laurel, reform school, in granite sill of south door on east side of brick workshop, on upper (outer) edge of sill, 0.15 meter from south end; bottom

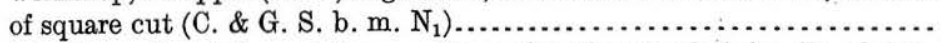

Ashland, southeast door of Duncan Memorial Chapel adjoining RandolphMacon College, 0.15 meter from south edge of sill, 0.155 meter from east side of brick wall, 0.184 meter from door jamb; bottom of square cut in sill (C. \& G. S. b. m. N) ......................................

190.930

219. 374

In Richmond and vicinity.

Richmond, 1.5 miles east of, top of stone coping to brick culvert under Chesapeake \& Ohio R. R., 140 meters east of milepost 81, on south end of culvert and on eastern or largest stone of coping on raised part of culvert; bottom of square hole lettered "U.S. $\square$ B.M." (C. \& G. S. b. m. P4)..

Richmond, corner of Seventeenth Street and Winston Alley, brick building owned by Davenport \& Morris and occupied by the Union Brokerage Commission \& Warehouse Co., at northeast corner of building and nearly on level with pavement, top of stone door and window sill (on which iron columns in front of building rest); bottom of square cut, lettered "U. S. C.

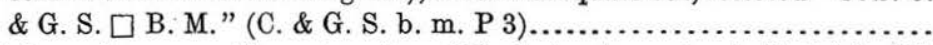

Richmond, corner of Seventeenth and Dock streets, on front of brick building owned and occupied by Davenport \& Morris, in granite sill of window at right-hand corner (as one faces the front of building); cross cut, lettered "U.S.C. \& G. S.+B.M." (C. \& G. S. b. m. P 2)...................

Richmond, flat surface of an offset on granite base to lamppost on left of steps leading to west entrance to new city hall (C. \& G. S. b. m. New City Hall)

Richmond, at head of Grace Street, in granite sill of east front door of Richmond College, near south end of sill, 0.142 meter from extreme east edge of sill and 0.174 meter from south edge of door; bottom of square cut (C. \& G. S. b. m. P)

112.405

19. 625

Richmond, at intersection of Poplar and Ash streets, in side of stone post 15 by 15 inches, iron plate facing river and inscribed "High-water line, 24 feet 1.8 inches above ordinary high tide, Oct. 1, 1870;" middle line of raised horizontal arrow on plate (C. \& G. S. b. m. city b. m.)........ 
STAFFORD QUADRANGLE.

[Latitude $38^{\circ} 30^{\prime}-38^{\circ} 45^{\prime}$; longitude $77^{\circ} 15^{\prime}-77^{\circ} 30^{\prime}$.]

From point near Summit to point near Widewater.

Fredericksburg, in sill of Princess Anne Street door to library in courthouse, near northwest corner of building, 0.051 meter from extreme east edge of sill and 0.11 meter from south side of door; bottom of square cut (C. \& G.

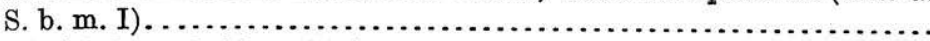

Feet.

69.066

Fredericksburg, bridge of Richmond, Fredericksburg \& Potomac R. R. over Rappahannock River, in northwest corner of stone coping of west abutment, below top of abutment and 0.181 meter from extreme east edge of stone in which it is cut, 0.056 meter from extreme north edge, 0.084 meter from abutment wall; bottom of square cut (C. \& G. S. b. m. H)....

Potomac Run station, near, in north stone abutment of iron railroad bridge over Potomac Run, west of track and at end of ironwork of bridge; bottom of square cut (C. \& G. S. b. m. G 8)

Brooke, a short distance south of station, in top of sandstone coping to retaining wall of brick culvert under railroad, east of track, near south end of wall above the arch; bottom of square cut, lettered "U.S. $\square$ B.M." (C. \& G. S. b. m. G 7)

Widewater, 0.5 mile south of, in top of retaining wall to brick culvert under railroad, east of track and near north end of wall above the arch; bottom of square cut, lettered "U. S. $\square$ B. M." (C. \& G. S. b. m. G 6)..........

TOANO QUADRANGLE.

[Latitude $37^{\circ} 15^{\prime}-37^{\circ} 30^{\prime}$; longitude $76^{\circ} 45^{\prime}-77^{\circ}$.]

From Williamsburg to Lanexa.

Toano, in top of brick foundation under railroad water tank, in top of third sill from track, 3.5 inches from west end and 2 inches from north side of foundation; bottom of square cut (C. \& G. S. b. m. Q 4)................

Diascond, in brick chimney of frame dwelling house owned by John Gordon and occupied by J. C. Glasebrook, in east side of chimney in eleventh course of bricks above ground, in third brick from northeast corner; copper bolt (C. \& G. S. b. m. Q 3)................................ Lanexa, near, in top of raised part of brick culvert under Chesapeake \& Ohio Ry. just above station, at north end of culvert and 0.5 meter from its west side; bottom of square cut, lettered "U. S. $\square$ B. M." (C. \& G. S.

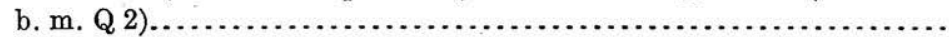

WILLIAMSBURG QUADRANGLE.

[Latitude $37^{\circ} 15^{\prime}-37^{\circ} 30^{\prime}$; longitude $76^{\circ} 30^{\prime}-76^{\circ} 45^{\prime}$.'

At Williamsburg.

Williamsburg, north side of courthouse near east end, in eleventh layer of bricks above watershed of building, in third brick from corner of north wing; copper bolt 0.058 meter long and 0.0125 meter in diameter (C. \&

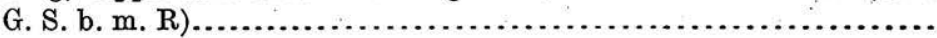

YORKTOWN QUADRANGLE.

[Latitude $37^{\circ}-37^{\circ} 15^{\prime}$; longitude $76^{\circ} 30^{\prime}-76^{\circ} 45^{\prime}$.]

At Lee Hall.

Lee Hall, in west wall of two-story brick outhouse in yard of E. C. Madison's residence, in seventh course above ground and in third brick from southwest corner; copper bolt (C. \& G. S. b. m. R 2)................ 


\section{APPENDIX B.}

\section{SECONDARY ELEVATIONS.}

Secondary elevations from records and topographic maps of the United States Geological Survey, including altitudes of well-known summits and other useful elevations, are given below. These elevations are approximate only and should not be used for accurate work.

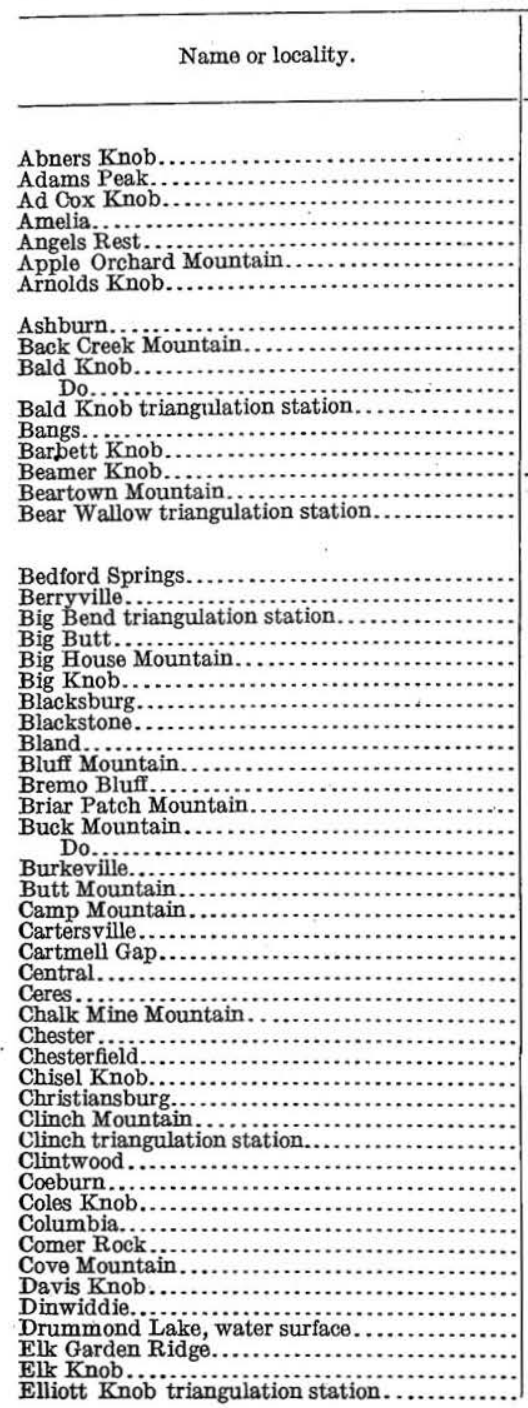

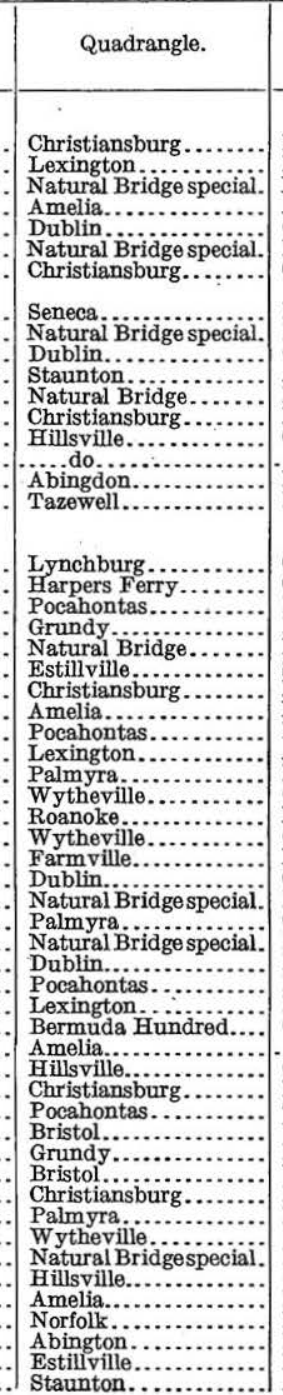

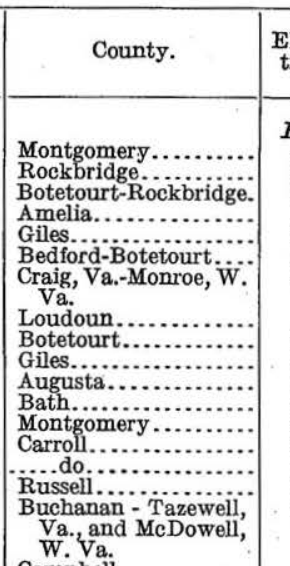

Elevation. Campbell

Clarke.

Bland-Wythe.

Buchanan-Russell....

Rockbridge.

Montgomery

Nottoway.

...............

Bland.

Amherst-Rockbridge.

Fluvanna

Roanoke.

Grayson.....................

Nottoway.

Giles.............................

Botecourt-Rockbridge

Cumberland.

Botetourt..........

Pulaski.

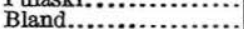

Rockbridge

Chesterfield................

C...do.

Carroll.................

Montgomery.

Tazewell.

Weshington...........

ashington. $\quad . . . . .4,223$

Dickinson............. $\mathbf{1}, 800$

Wise................ 1,981

Floyd................ 2,903

Fluvanna............. 206

Grayson-Wythe....... 4, 113

Botetourt.......... 2,073

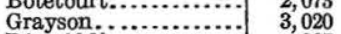

Dinwiddie................. $\quad 267$

\begin{tabular}{r|r} 
& 22 \\
& Nansemond-Norfolk...
\end{tabular}, 250

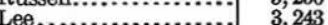

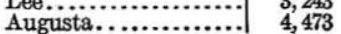




\begin{tabular}{|c|c|c|c|}
\hline Name or locality. & Quadrangle. & County. & $\begin{array}{l}\text { Eleva- } \\
\text { tion. }\end{array}$ \\
\hline & & & Feet. \\
\hline (n) & Appomattox............. & Appomat & \\
\hline $\begin{array}{l}\text { Evington.. } \\
\text { Farmille. }\end{array}$ & $\begin{array}{l}\text { Lyncnburg } \\
\text { Farmville. }\end{array}$ & $\begin{array}{l}\text { Campbell........ } \\
\text { Prince Edward... }\end{array}$ & \\
\hline (1) & Hillsville.. & Carroll............ & 3,216 \\
\hline Fincastle..... & Roanoke.. & Botetour & 1,250 \\
\hline Flattop triangulation sta & ....do... & Bedford & 4,001 \\
\hline 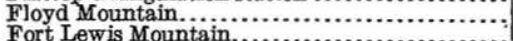 & Natural Bri & Botetour & 3,149 \\
\hline 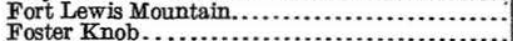 & Christiansburg ........... & Roanoke & 3,328 \\
\hline (n) & Roanoke. & Bedford. & 2,576 \\
\hline Gibson Knob & $\begin{array}{l}\text { Bristol..... } \\
\text { Hillsville.. }\end{array}$ & $\begin{array}{l}\text { Wise... } \\
\text { Carroli. }\end{array}$ & $\begin{array}{l}2,305 \\
3,336\end{array}$ \\
\hline Goode....... & Lynchburg & Bedford. & $\begin{array}{r}0,000 \\
728\end{array}$ \\
\hline Grassy Hill. & Roanoke.. & Franklin & 1,968 \\
\hline Grassy Moun & Natural Bridge special. & ockbridge & 3,358 \\
\hline 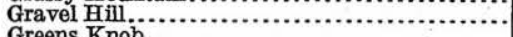 & Palmyra. & Buckingh & 458 \\
\hline 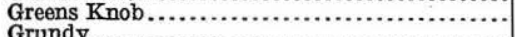 & Roanoke.. & Bedford. & 2,563 \\
\hline $\begin{array}{l}\text { Grund } \\
\text { Gully Mountain }\end{array}$ & Grundy... & lana & 1,065 \\
\hline (n) & Natural Br & Botetour & \\
\hline Hampden Sidn & $\begin{array}{l}\text { Hillsville. } \\
\text { Farmville. }\end{array}$ & $\begin{array}{l}\text { Wythe... } \\
\text { Prince Ed }\end{array}$ & $\begin{array}{r}3,163 \\
539\end{array}$ \\
\hline Hawks Bill... & Luray..... & Madison-P & 4,066 \\
\hline Hayter Knob. & Abingdon & Russell-W & 4,200 \\
\hline 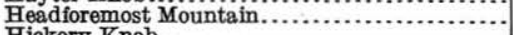 & Roanoke.. & Bedford.. & 3,779 \\
\hline Hickory Knol & Lewisburg & $\begin{array}{l}\text { Alleghan } \\
\text { brier, W }\end{array}$ & 3,351 \\
\hline Highco Mour & Lexington & ockbridge.. & 2,880 \\
\hline High Knob. & Estillville & Wise.. & 4,188 \\
\hline Do.: & Luray... & Fauqui & 2,385 \\
\hline $\begin{array}{l}\text { gh Point. } \\
\text { gh Rock.. }\end{array}$ & Dublin. & Gil & 3,910 \\
\hline gh Rocks & "̈odo..... & Bland-V & 3,837 \\
\hline Isville.... & Hillsville..... & $\begin{array}{l}\text { Wythe. } \\
\text { Carroll. }\end{array}$ & $\begin{array}{l}3,660 \\
2,570\end{array}$ \\
\hline Humpback M & Buckingham. & Augusta- & 3,645 \\
\hline np Rock. & Lexington & Rockbridg & 3,190 \\
\hline (n....... & Farmville. & Cha & 625 \\
\hline 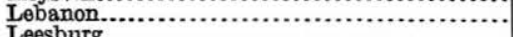 & Bristol... & $\mathrm{Ru}$ & 2,131 \\
\hline 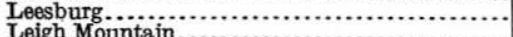 & $y \ldots \ldots$ & Lo & 321 \\
\hline 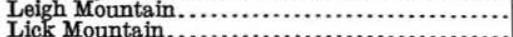 & ......... & Prin & 715 \\
\hline tle Hountain............ & Lewisburg ........ & Alleghany... & $\begin{array}{l}2,990 \\
3,410\end{array}$ \\
\hline Lookout Mountain...... & Wytheville.......... & $\begin{array}{l}\text { Rockbridge } \\
\text { Grayson... }\end{array}$ & $\begin{array}{l}3,410 \\
4,623\end{array}$ \\
\hline Lynch................ & Lynchburg.......... & Can & 730 \\
\hline nville Mo & Roanoke.. & Franklin & 2,280 \\
\hline $\mathrm{Kno}$ & $\mathrm{rg} . .$. & $\mathrm{R}$ & 3,201 \\
\hline Mountain... & ........... & ki. & 3,404 \\
\hline leys Top........ & don. & Sn & 3,290 \\
\hline n.................. & Luray..... & ck.. & 3,523 \\
\hline (n) & $\begin{array}{l}\text { Christiansburg...... } \\
\text { Hillsville............. }\end{array}$ & noke.... & \\
\hline $\begin{array}{l}\text { Max Meadows } \\
\text { Mays Mountair }\end{array}$ & 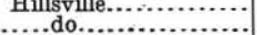 & $\begin{array}{l}\text { Wythn. } \\
\text { do... do. }\end{array}$ & $\begin{array}{l}2,028 \\
2,849\end{array}$ \\
\hline herrin...... & Farmville & Lunenhi & $\begin{array}{r}2,849 \\
589\end{array}$ \\
\hline ............ & Winc & Fre & \\
\hline$\cdots$ & Roa & Roanoke.. & 2,366 \\
\hline$\cdots$ & Mont & reland. & 138 \\
\hline iang & Taze & Tazewell & 4,510 \\
\hline 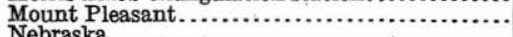 & Lexin & Amher & 4,098 \\
\hline (n) & tox. & ttox & \\
\hline . & 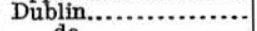 & Pulaski. & \\
\hline cholls Knob & ....do. & aijo. & 1,757 \\
\hline $\begin{array}{l}\text { Nicholls Knob... } \\
\text { Nottoway....... }\end{array}$ & $\begin{array}{l}\text { Lew } \\
\text { Farr }\end{array}$ & All & $\begin{array}{r}3,573 \\
421\end{array}$ \\
\hline & Hills & Grayson. & 2,485 \\
\hline ain.... & Roar & Bedford. & 3,828 \\
\hline Mountain. & al Bridgespecial. & Botetourt. & 3,456 \\
\hline ......... & tox...... & Appomattox.. & 678 \\
\hline 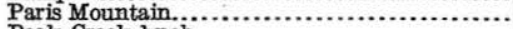 & nsburg. & nery & \\
\hline b......... & (n)............. & $\mathrm{Pu}$ & \\
\hline ation.. & Tazewel & Tazew & \\
\hline $8 \mathrm{Mov}$ & Bridgespecial. & $\mathrm{Gr}$ & \\
\hline $\mathrm{Mol}$ & $\begin{array}{l}\text { Natural Bridgespecial. } \\
\text { Christiansburg......... }\end{array}$ & $\begin{array}{l}\text { Botetourt } \\
\text { Roanoke. }\end{array}$ & $\begin{array}{l}2,220 \\
3,960\end{array}$ \\
\hline Knob. & Hillsville..... & Carroll. & 3,039 \\
\hline ............... & ......do. & .....do.. & 3, \\
\hline c...... & & & 3,166 \\
\hline ts Mountain... & wisbu & -Monroe, & 3,829 \\
\hline $\mathbf{P}$ & Antieta & Loudoun & 1,387 \\
\hline 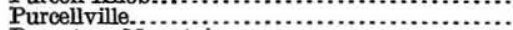 & Har & & \\
\hline Iountair & Natural Bridgespecial & Botetour & 3,037 \\
\hline $\mathrm{y} \mathrm{Knob}$. & Hillsville. & Carroll. & 2,935 \\
\hline ob. & Wytheville & Wythe. & 3,204 \\
\hline Mountain. & Luray. & Madison. & 3,398 \\
\hline & & & \\
\hline
\end{tabular}




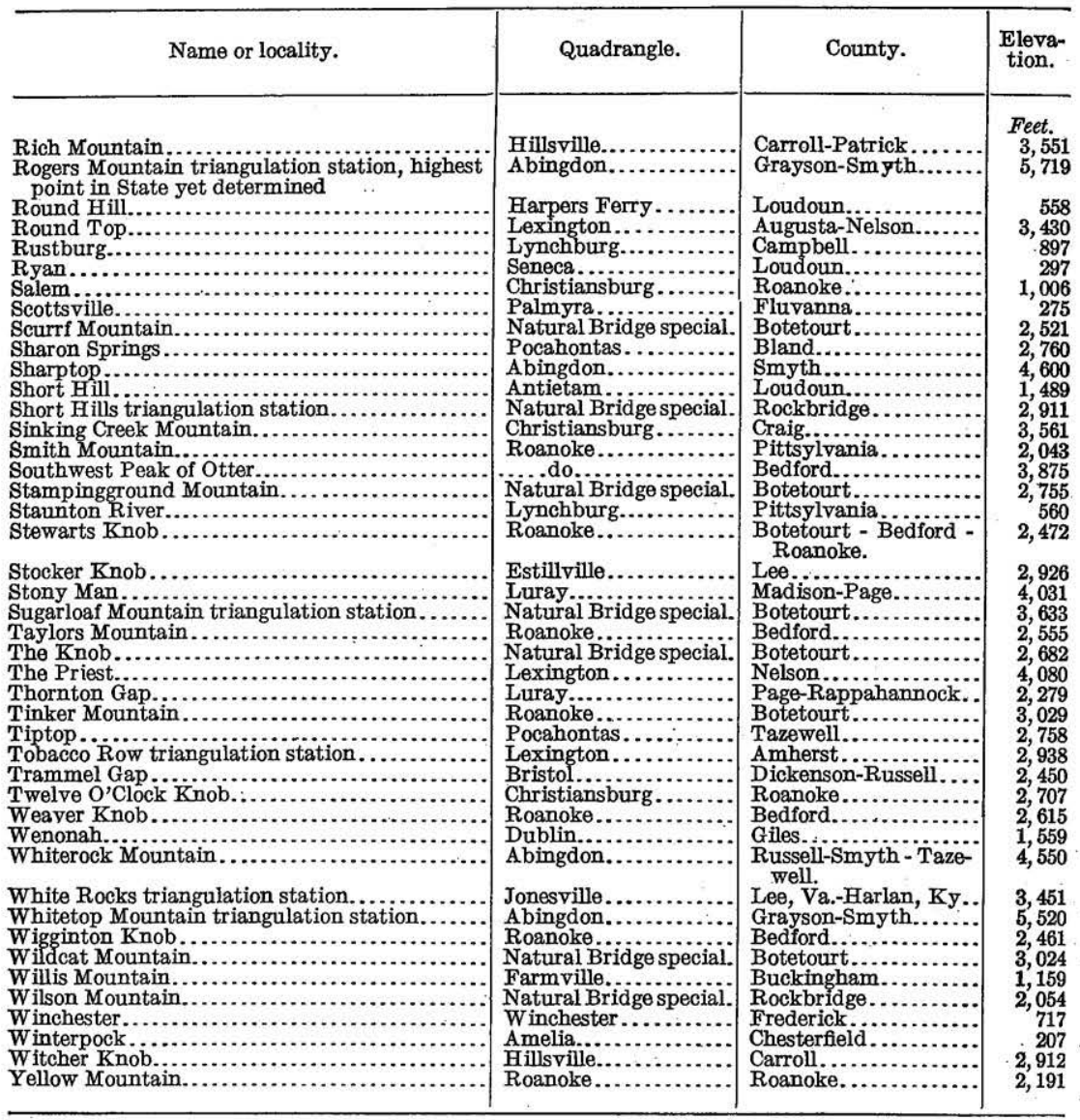




\section{INDEX.}

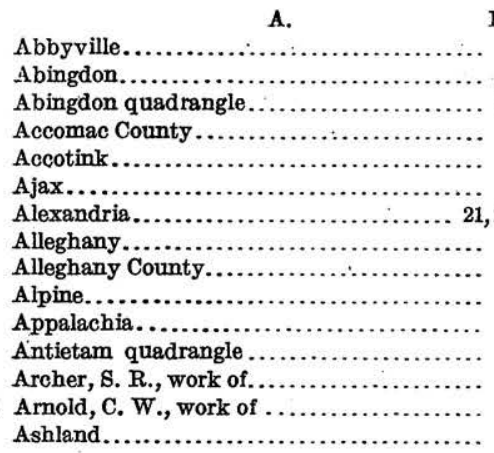

B.

Backbone.

Bacons Castle.

Bailey

Baileys Crossroads.

Baldwin.

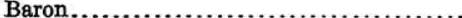

Bassett.....................................

Battery Park.

Beatrice.

Belfast Mills

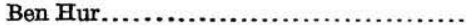

Bench marks, description of plate showing.

Bessemer.

Big Stone Gap.

Big Stone Gap quadrangle

Biggs, L. F., work of..................... 41

Birchleaf.............................. 47

Blackford.............................. 50,56

Bondtown.............................. 49

Bonsacks quadrangle.................. 10-11,31

Boones Mills............................. 10

Botetourt County......................... 8,31

Bowling Green quadrangle................. 58

Boydton quadrangle...................... 30

Braddock............................... 22

Braddock Heights........................ 22

Bramwell quadrangle............... 13,36-37,42

Broad Ford ............................. 40

Brooke.................................. 61

Brookneal............................... 30

Brookneal quadrangle...................... 30

Buchanan........................... 11,34,35

Bucu..................................... 44

Bucu quadrangle........................ 42-44

Buffialo Junction........................... 26

Bull Run................................ 18, 20
Page.

Burke.................................. $\quad 22$

Burkes............................... 19

Burkes Garden quadrangle................

Burketons.............................. 12

\section{C.}

Cahas Mountain quadrangle............. 10,29-30

Callaghan............................... 13

Callaghan quadrangle..................... 13

Callands quadrangle...................... 29

Campbell, N. A., work of.................. 8

Campbell County........................... $\quad 25$

Canterton............................. 51

Carolina, Clinchfield \& Ohio Ry........ 47, 49,54

Caroline County......................... $\quad 58$

Castlewood................................. 48

Caylor.................................. 50

Cedar Bluff............................... 54

Chain Bridge........................... 23

Chantilly.............................. 18

Charles City quadrangle................... 58

Charlotte County......................... 25

Chatham Hill............................. 40

Chatham quadrangle .................... 28-29

Cherrydale................................ $\quad 25$

Cherrydale Heights......................

Chesapeake \& Ohio Ry........ 8, 12,13,15, 16, 33, 34

Chilhowie............................... 39

Christie................................... 30

Clark.................................. 23

Clarksville...................... 8, 9, 25, 26, 30

Clarksville Junction...................... 26

Clarksville quadrangle................. 8 -9, 25-26

Clarkton.................................. 27

Cleveland.............................. 51

Clifton................................... is

Clifton Forge ........................... 12

Clifton Forge quadrangle.................. 12

Clintwood.......................... 45, 46, 48, 53

Clintwood quadrangle .................... 45-48

Clover.................................. 27

Clover quadrangle....................... 26-27

Cloverdale................................ 11

Cluster Springs.......................... 31

Coast and Geodetic Survey, elevations by ... $58-61$

Coeburn..................................... 49

Coeburn quadrangle...................... 48-49

Colley............................... 43,44, 47

Covington............................... 12,13

Craig County............................ 31

Craig Valley R. R..................... 31, 33

Craigs Creek quadrangle...................... $31-32$

Croaker............................... 14,15

Crystal Hill. ................................. 27

Cumberland Gap......................... 37 


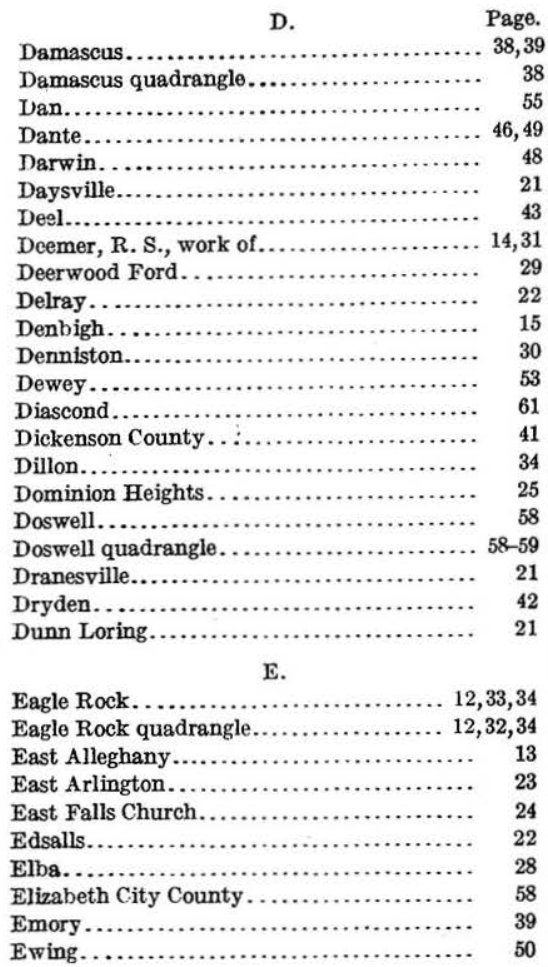

\section{F.}

Fairfax County

Fairfax Courthouse.

Fairfax quadrangle

Falls Church

Falls Mills.

Farmer, R. A., work of.

Farmers.

.......... 9,10

Fincastle............................ 31,32,33

Fink ............................... 48,49

Finney................................. 50

Five Oaks........................... 45

Flat Gap................................ 53

Foraker............................... 48

Forestville.............................. 17

Fort Monroe............................ 59

Foust, F. L., work by ................... 37

Franklin City .......................... 14

Franklin County.........................

Fredericksburg.

Furnace.

\section{G.}

Gala.

Gardner.

Giles County .

Gillespie.

Gilmore Mills

Given.

Glade Hill

Glade Springs quadrangle.
Page.

Glamorgan ............................. 52

Glenlyn............................. 13,57

Glen Wilton ........................... 12

Gloucester............................. 15

Gloucester County....................... 14

Gloucester Point........................ 15

Grafton............................... 16

Graham......................... 13, 36, 37, 42

Grayson County........................ 38

Green, T. A., work of ...................... 13,14,31,36

Grove................................. 15

Guinea.................................. 58

H.

Haden................. 12

Halbert, E. O., work of. .................. 25

Halifax County....................... 25

Hallwood quadrangle...................... 14

Hampton................................ 16

Hampton quadrangle..................... 16,59

Hanger................................. 44

Hanover County............................ 58

Hansonville quadrangle.................50-51

Harpers Ferry ............................ 36

Haymarket quadrangle.................... 20

Haysi.................................. 47

Hayter Gap......................... 40;41

Hebron Church................................ 31,

Henrico County .......................... 58

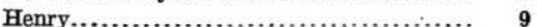

Henry County............................ 8

Highgate................................ 16

Highview Park............................. 24

Hipes.............................. 34

Hodges, J. W., work of ................... 14

Hogans................................. 50

Hollins.............................. 11

Honaker............................. 42,55

Horton, A. H., work of ..................... 25

Houston............................ 27,31

Hubbard Springs....................... 50,55

Hurt.............................. 28

I.

Ilda.............................. 17, 19,21

Indian Head quadrangle.................. 20

Indian Rock........................... 34

Iron Gate................................ 12

Isle of Wight County....................... 14

Isle of Wight quadrangle.................. 16

J.

James City County ..................... 14,58

Jamestown .............................. 16

Jerrys Run............................ 13

K.

Kanawha \& Michigan Ry................... 8

Kenmore.............................. 17

Kings Corners......................... 16

Kiser................................... 51

Konnarock ........................... 38,39

L.

Lanexa................................. 61

Langley .................................... 23

Laurel..................................... 


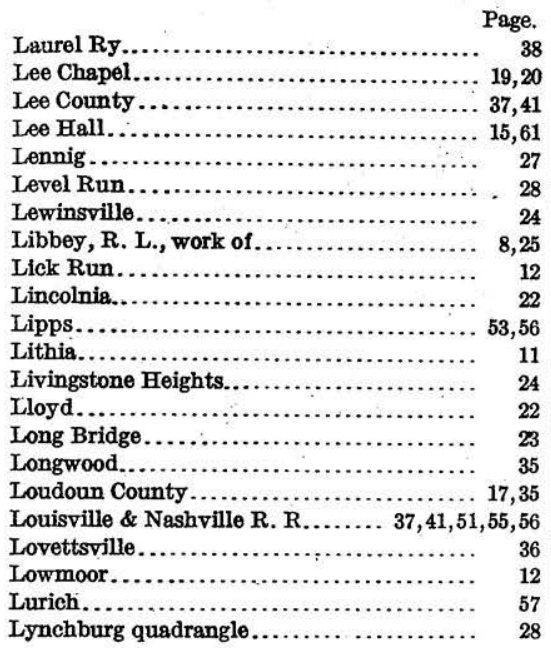

\section{M.}

McLean ............................. 23,24

McMaugh, F. J., work of ................... 17

Mahala................................. 21

Mallow.................................. 12

Manassas.............................. 19,20

Maps, topographic, list of ................... 7-8

Marion................................ 39,40

Marion quadrangle........................ 38

Mart.................................. 47

Martinsville................................. 9

Martinsville quadrangle.................. . 9

Massey.................................. 14

Maxwell.................................. 54

Mayo................................ 30

Meadow View ............................. 38

Mecklenburg County ..................... 8,25

Merrifield................................... 21

Metcalfe, J. B., work of............... 17,38, 41

Middlesboro quadrangle ................... 37,51

Milford................................. 58

Moneta quadrangle......................... $\quad 29$

Moores Place............................ 16

Morrison ................................ 59

Moss Run................................ 13

Motley..................................... 28

Mount Ids................................ 23

Mount Rogers quadrangle................... 38

Mount Vernon quadrangle................ 59

Murat................................... 35

N.

Nace.

Nathalie...............................

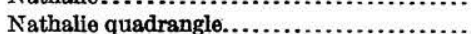

Natural Bridge............................ 35

Natural Bridge quadrangle............... 11, 34-35

Neathery.................................. 27

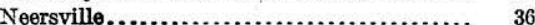

Nelson.............................. 26

Nemours, W. Va......................... 37

New Kent County...................... 58

Newport News........................... 16,60

Newport News quadrangle.

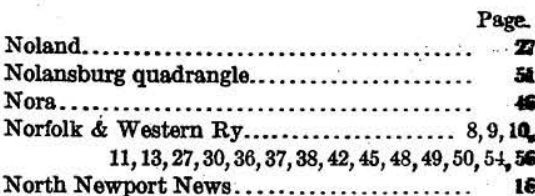

Norton.................................... 52,56

Novelty

\section{o.}

Oakdale.....................................

Oaktree........

Ocoonita................................ 5

Ohlinger....................................

Old Point Comfort ..................... 16, 52

Old Rosedale........................... 41,30

Ordinary ................................. is

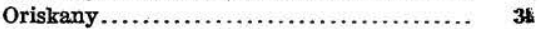

\section{$\mathrm{P}$}

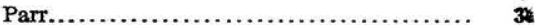

Penhook.................................. 28

Pennington.........................

Penola...........................

Personnel, record of .....................

Perth....................................... 28,38

Peterstown, w. Va.....................

Peterstown quadrangle...................... 13,

Pine.....................................

Pinnacle..................................

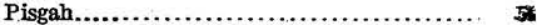

Pittsville..................................

Pittsylvania County...................... 25,

Pleasant Valley.......................... is

Pocahontas...............................

Pocomoke City.........................

Pohick Creek............................ 20,

Potomac Run............................ 66

Pound.................................. 52,

Pound quadrangle....................... 52-5s

Pounding Mill.....................,

Pounding Mill quadrangle................. st

Prater....................................

Precise leveling, definition of.............. $5-6$

Primary leveling, definition of ............. $5-5$

Prince William County.................. 17, ss

Providence Forge.........................

Publication, previous

\section{Q.}

Quantico................................

\section{R.}

Randolph $\ldots \ldots \ldots \ldots \ldots \ldots \ldots \ldots \ldots \ldots \ldots \ldots, 26,2 \pi$

Rapps Mill ............................ 35

Raven..................................... 55

Ravensworth........................... 22

Redwood................................

Regina quadrangle......................... 5

Rich Creek.....................................

Richlands............................ 54, 55

Richlands quadrangle $. . \ldots \ldots \ldots \ldots \ldots \ldots \ldots, 54,55$

Richmond.............................. 60

Richmond, Fredericksburg \& Potomac

R. R.......................... 22, 59, 60,61

Richmond quadrangle.....................

Ridgeway................................ 


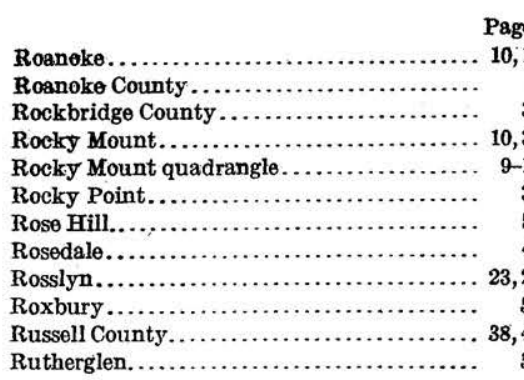

s.

St. Asaph

St. Clair.

St. Elmo.

St. Paul.

Salisbury.

Saltpetre Cave.

Saltville.

Sand Lick. .........

Sandy Level.

Scotland

Scottsburg........................... 27,31

Sea level, mean, definition of .............. 6-7

Secondary elevations.................... 62-64

Seminary ............................. 22

Semper, C. H., work of.................. 8, 13

Seneca quadrangle...................... 20-21

Senseney, H. S., work of................. 31, 41,56

Septa.................................. 15

Shawanee................................. 51

Sideburn........................... 19

Signpine.................................. 15

Skeggs.............................. 43,44

Smithfield................................ 16

Smyth County......................... 38

Sneed ville quadrangle.................... $\quad 55$

snow Hill quadrangle.................... 14

Soudan................................ 8

South Boston......................... 31

South Clarksville........................ 26

Southern Ry............ 8, 22, 26, 27, 28, 29, 30,31

Springfield (Washington quadrangle)........ 22

Springfield (Yorktown quadrangle).......... 15, 16

Springwood........................... 11,32

Stafford County .......................... 58

Stafford quadrangle...................... 61

Starkey.................................. 10

Sterling ................................ 18, 20

Stonehouse............................... 20

Stratton................................ 46

Strom .................................. 34

Summit............................. 58,61

Surber................................. 34

Surry County ......................... 14
Page.

Swords Creek............................ 55

Sycamore.............................. 28

T.

Tacoma............................... 56

Tandy ............................, 47

Taylors Valley .......................... 39

Taylorstown .......................... $\quad 36$

Tazewell............................. 45,54

Tazewell County $\ldots \ldots \ldots \ldots \ldots \ldots \ldots \ldots, 13,36,41$

Tiny ...................................

Tip Top.............................. 45

Toano..................................... 61

Tormo quadrangle..................... 14,61

Toshes............................... $\quad 29$

Troutville ............................. 11

Tyson Crossroads...................... 21, 24

U.

Union Hall............................. $\quad 29$

v.

Van Sant.............................

Vicey .............................. 44, 47

Virgilina.............................. 30

Virgilina quadrangle..................... 30-31

Virginia-Carolina Ry...................... 38,39

Virginia City............................ 48

w.

Waidsboro............................ 10

Warwick County......................... 14,58

Washington County ......................... 38

Washington quadrangle..................... 21-25

Watauga................................ 38

Watkins................................ 27

West End.............................. 15

West Falls Church..........................

Wheeler................................ 51

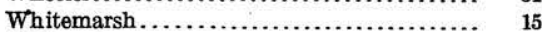

Widewater............................ 59, 61

Willard................................... 18

Williamsburg ....................... 14, 16,61

Williamsburg quadrangle................. 14-15

Winstead, W. R., work of ................. 35

Wirtz................................. 10

Wise County ............................... 41

Wise quadrangle.......................... 56

Wise Terminal R. R ...................... 56

Witherspoon, E. E., work of.............. 17

Wittens Mill............................ 45

Wolftrap................................ 31

Woodbridge............................... 59

Wright................................ 10

York County......................... 14,58

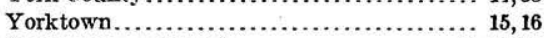

Yorktown quadrangle................. 15-16, 61

Youngs ................................ ${ }_{54}$ 
Lithomount

Pamphlet

Binders

Gaylord Bros. Inc.

Makers

Syracuse, N. Y. 

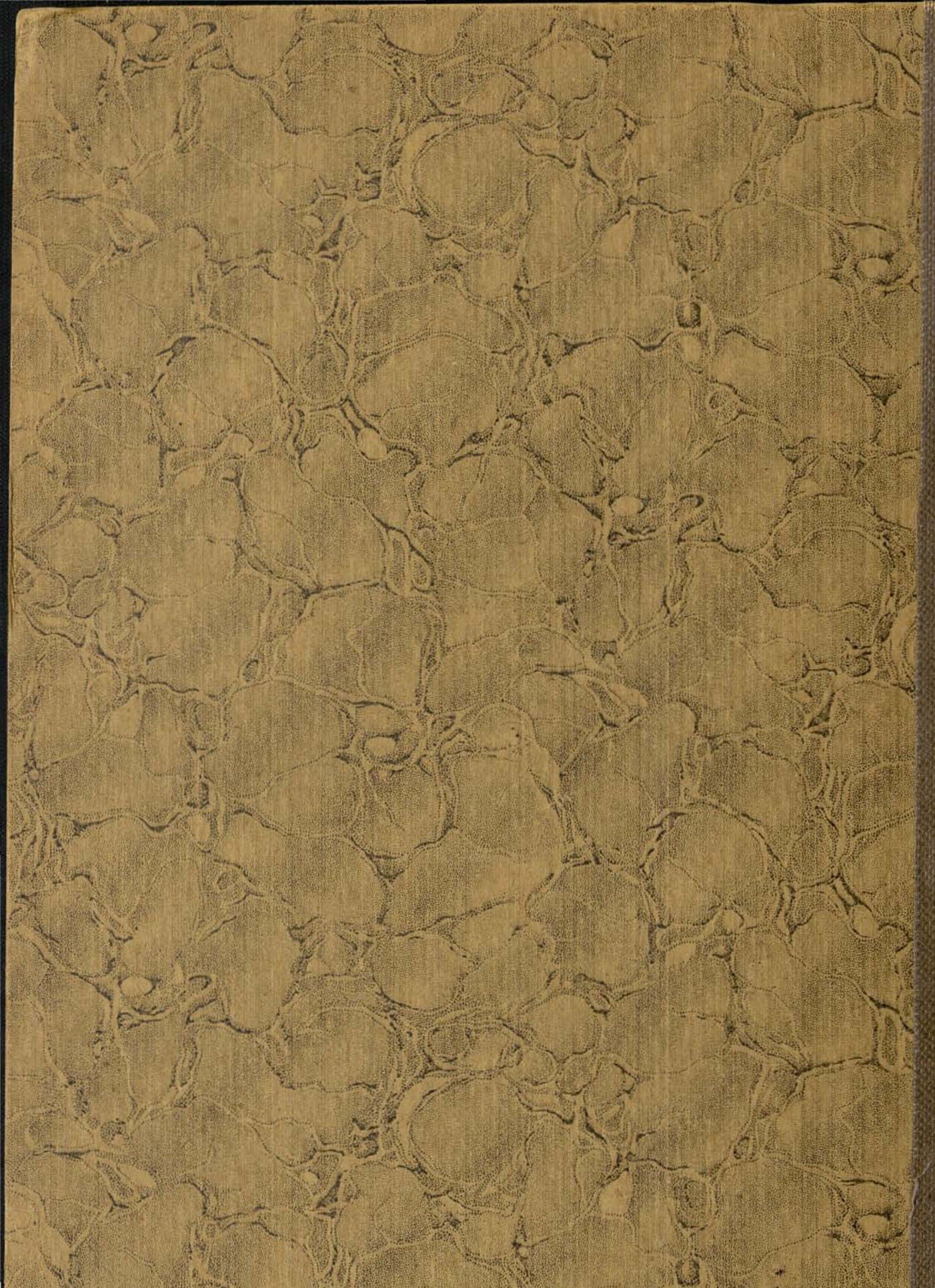

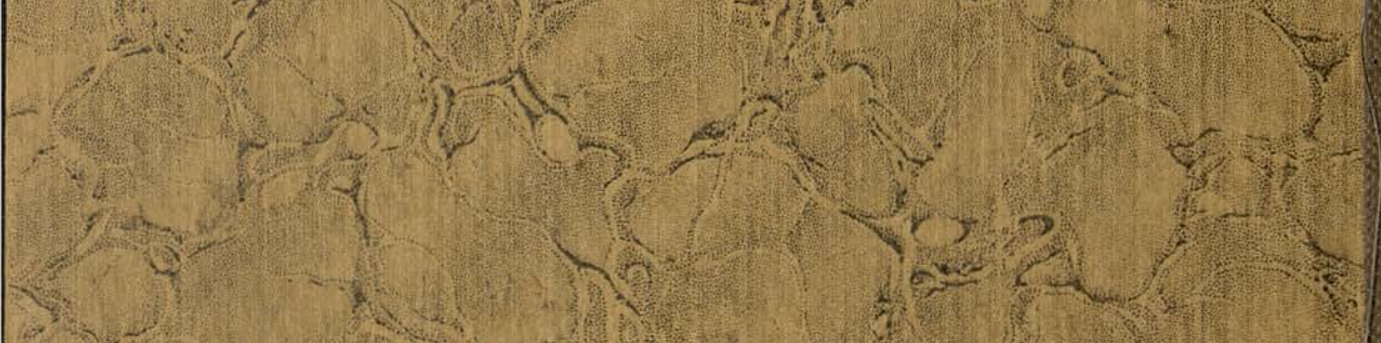

